\title{
The NeOGENE SEISMIC STRATIGRAPHY AND UPLIFT HISTORY OF The Otago Shelf, NeW ZEALAND
}

By

\author{
Michael Clark
}

A thesis submitted to Victoria University of Wellington in partial fulfilment of requirements for the degree of Master of Science in Petroleum Geoscience

School of Geography, Environment, and Earth Sciences Victoria University of Wellington 


\section{Abstract}

The Otago continental shelf is a prospective petroleum area on the east side of the South Island New Zealand. During the Neogene it evolved from a post-rift to passive margin as giant progrades extended eastward across the shelf, fed by tectonic uplift and erosion of the Southern Alps to the west. Seismic reflection profiles reveal an uplifted limestone horizon near the Dunedin Volcano. This may be caused by a buoyant load under the lithosphere and can be spatially and temporally linked to the Dunedin Volcano and geophysical anomalies in the area.

This thesis utilises 2D and 3D seismic data to map Neogene sequence boundaries over the Otago Shelf. Seven such sequence boundaries have been mapped based on distinctive seismic characteristics above and below these surfaces. These surfaces have been tied to nearby petroleum and Integrated Ocean Drilling Project wells using biostratigraphic data and then used to generate a series of isopach and depth maps that document the Neogene evolution of this margin. The maps depict the deposition of Neogene sediment and provide age constraints to structural events in the basin such as the uplift near Dunedin and fault movement on the Endeavour High.

The maps are then used to develop a lithospheric flexure model where uplift is interpreted to have been caused by asthenospheric upwelling beneath Dunedin. The model provides insight into the conditions that led to the flexure of the lithosphere, specifically the elastic thickness of the plate and the magnitude and depth distribution of buoyant intrusive material that fed the Dunedin Volcano. Asthenospheric upwelling explains elevated heat flow around Dunedin and would result in enhanced petroleum maturity. This highlights the potential for petroleum generation in source rocks immediately offshore from Dunedin.

Keywords: Neogene; Otago; Dunedin; Canterbury Basin; New Zealand; seismic; flexure; asthenospheric upwelling. 
Who would sail the seven seas and share a sailor's fate?

Eastward round by Dusky Sound, and Pegasus - through the Strait, Port Cooper, Ocean, Tom Kain's Bay, for that is the coaster's fate.

Extract from a variant of 'Across the Line' circa 1840 


\section{Acknowledgements}

I would like to thank Tim Stern (Victoria University) and Greg Browne (GNS

Science) for supervision and advice. Thanks to the people at Schlumberger Information Solutions Australia and OMV New Zealand for providing me with software and being receptive of my studies. I want to thank Ivana Stefanovski, Jordan Mills, Aaron Johnston and others for proofreading. I am grateful for the comments and help of numerous others such as Hongbo Lu, Craig Fulthorpe, Wayne Mogg, Angela Slagle, Karl-Heinz Zelt, Tim Allan, Tony Harrison, Rachael Gavey and too many others to name. 


\section{Table of Contents}

Table of Contents......................................................................... vi

List of Figures ............................................................................... vii

List of Tables ............................................................................

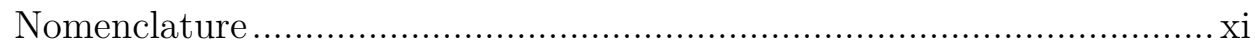

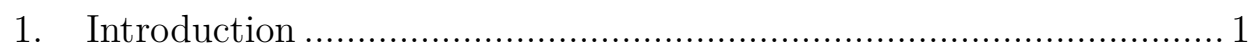

1.1 Motivation for this thesis ................................................ 1

$1.2 \quad$ Project Aims .............................................................. 2

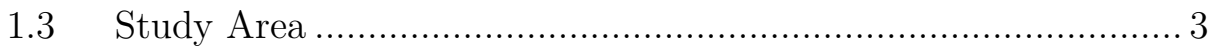

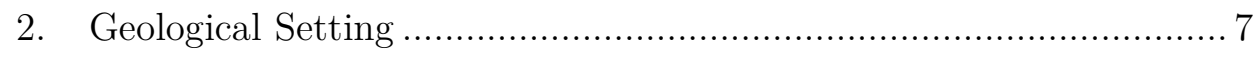

2.1 Canterbury Basin .......................................................... 7

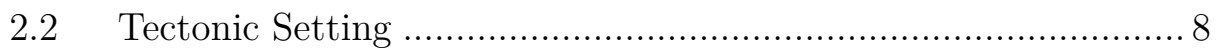

2.2.1 Physiographic Setting ............................................... 10

2.2.2 Alpine Fault ............................................................ 11

2.2.3 Subsidence ................................................................... 13

$2.3 \quad$ Sedimentation......................................................... 13

$2.4 \quad$ Seismic Stratigraphy................................................. 15

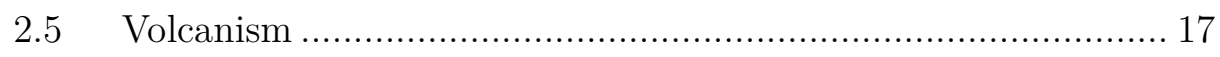

2.6 Geophysical Anomalies near Dunedin Region......................... 18

$2.7 \quad$ Petroleum Potential............................................................. 20

3. The Neogene Seismic Stratigraphy of the Otago Shelf ................. 25

3.1 Introduction.................................................................. 25

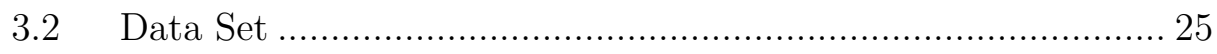

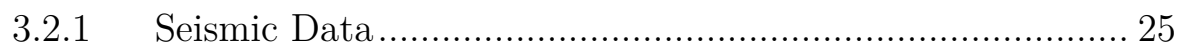

3.2.2 Wells .................................................................. 26

3.2.3 Well Tops and Biostratigraphy ..................................... 27

3.3 Method ............................................................................. 28

3.3.1 Well Correlation ..................................................... 28

3.3.2 Well to Seismic Ties .................................................. 28

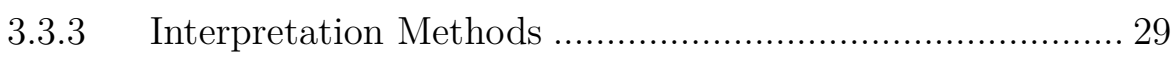

3.3.4 Interpreted Horizons ................................................ 30

3.3.5 Gridding and Depth Conversion...................................... 31

3.4 Results and Discussion ................................................. 31

3.4.1 Uncertainty .............................................................. 36

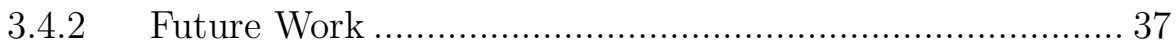

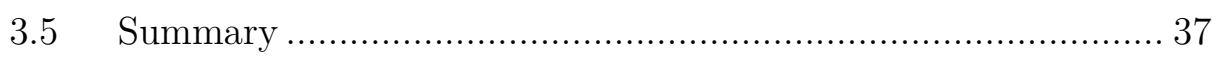

4. Three-Dimensional deformation of the Otago Shelf...................... 41 


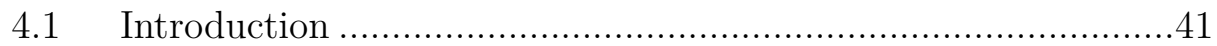

$4.2 \quad$ Lithospheric Flexure ................................................... 42

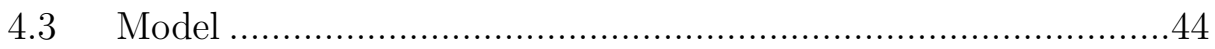

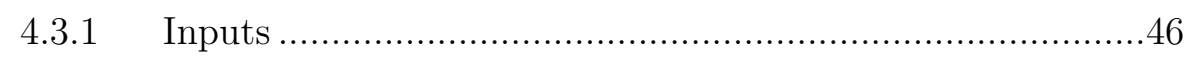

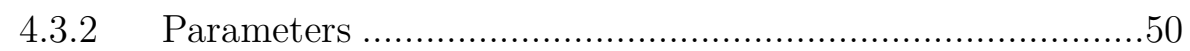

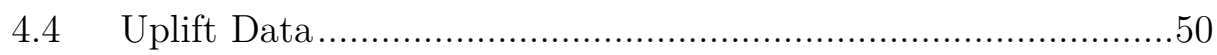

4.4.1 Adjusting for depositional depth................................52

4.4.2 Adjusting for post-depositional deformation.....................52

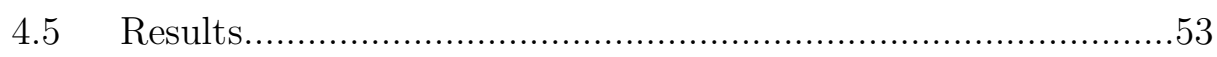

4.6 Discussion...................................................................... 54

4.6.1 Relevance to the Petroleum System ................................58

4.6.2 Further work................................................................61

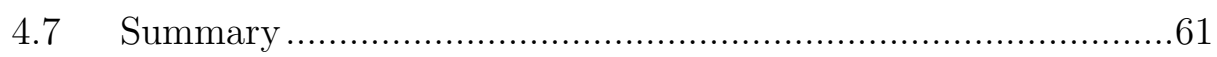

5. Summary and Conclusions................................................65

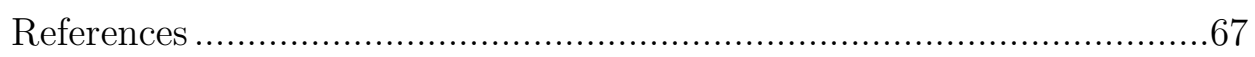

Appendix 1. Seismic and wells used in this thesis .............................77

Appendix 2. Data for time-depth correlation ..................................79

Appendix 3. Description of interpreted horizons ..................................8 81

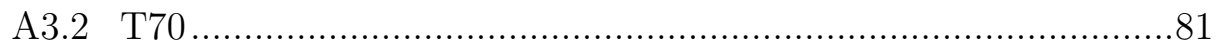

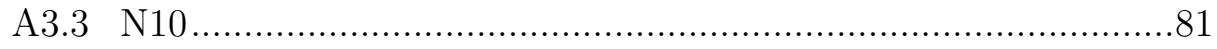

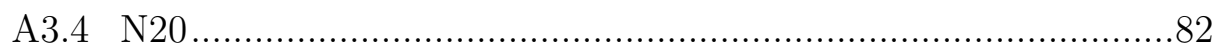

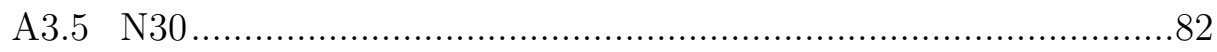

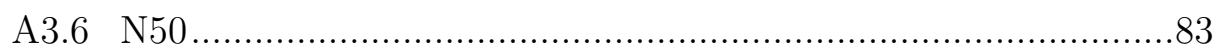

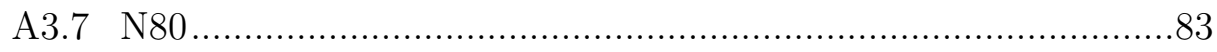

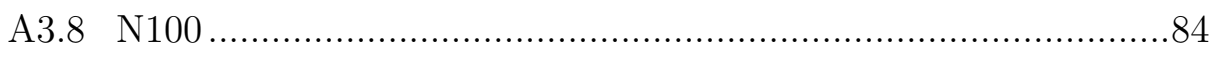

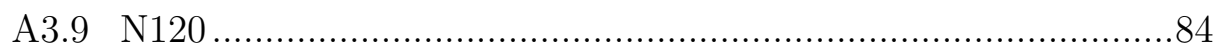

Appendix 4. Large Maps .................................................................. 85 


\section{List of Figures}

Fig. 1.1: Map of the study area showing 2D and 3D seismic data used in this

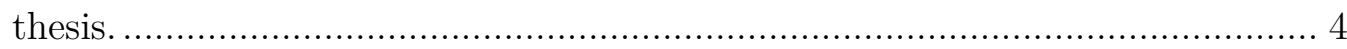

Fig. 2.1: Location map showing features and currents ................................. 7

Fig. 2.2: New Zealand tectonic plate reconstructions ................................... 9

Fig. 2.3: Convergence differs along the strike of the Alpine Fault...................12

Fig. 2.4: Tectonic subsidence curves for the Clipper-1 exploration well ...........13

Fig. 2.5: Schematic large-scale stratigraphy of the Canterbury Basin..............14

Fig. 2.6: Canterbury Basin horizons and events .............................................16

Fig. 2.7: Late Cenozoic basalts in the onshore Dunedin area.........................17

Fig. 2.8: Seismic data has revealed crustal anomalies beneath Otago..............19

Fig. 2.9: A petroleum systems diagram for the Galleon-1 exploration well......23

Fig. 3.1: Comparing functions to convert time and depth............................29

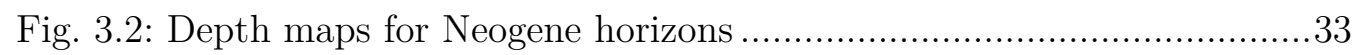

Fig. 3.3: Isopach maps for Neogene horizons ......................................... 34

Fig. 3.4: Neogene horizons onlap onto the Endeavour High on transect c-c' ...38

Fig. 3.5: Correlation of horizons between the wells on transect a-a' ...............39

Fig. 3.6: North-to-south transect b-b' of Fig. 1.1.....................................40

Fig. 4.1: An illustration of flexural uplift as set out in the model...................45

Fig. 4.2: Block diagram of flexure model .................................................... 45

Fig. 4.3: A comparison of the anomalies around Dunedin............................49

Fig. 4.4: Depth map of the uplifted limestone horizon ..............................51

Fig. 4.5: A, The input load B, Modelled upward deflection. .........................55

Fig. 4.6: A, Modelled and observed uplift on a southeast transect A-A' ........55

Fig. 4.7: Testing the models sensitivity .................................................56

Fig. 4.8: Excess heat flow is produced at the surface by hot emplacements ....60

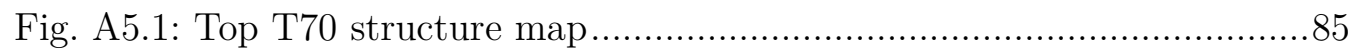

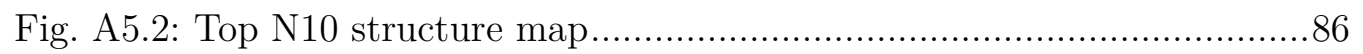

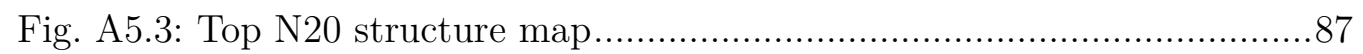

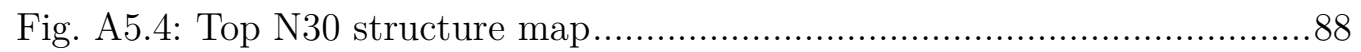

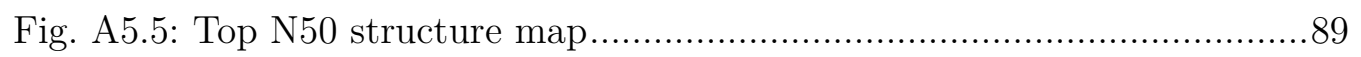

Fig. A5.6: Top N80 structure map.................................................... 90

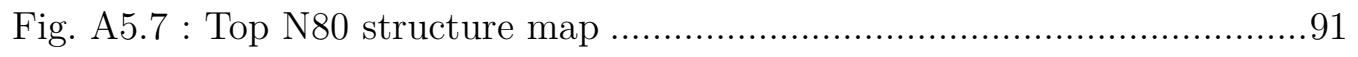

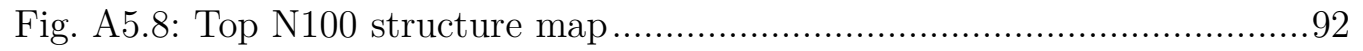

Fig. A5.9: Seafloor structure map.................................................... 93

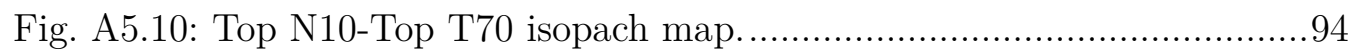

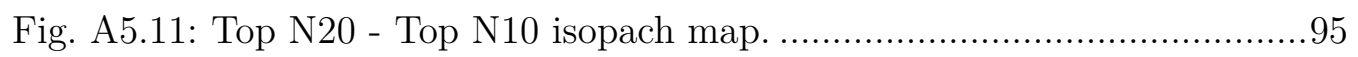

Fig. A5.12: Top N30 - Top N20 isopach map. .............................................96

Fig. A5.13: Top N50 - Top N30 isopach map. .............................................97 
Fig. A5.14: Top N80-Top N50 isopach map............................................ 98

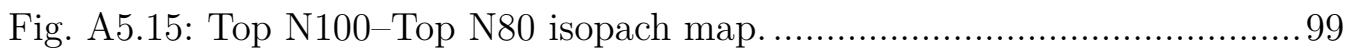

Fig. A5.16: Seafloor-Top N100 isopach map................................................ 100 


\section{List of Tables}

Table 4.1: Parameters used in generating the buoyant load..........................48

Table 4.2: Parameters used in flexural modelling. .........................................51

Table 4.3: Comparison of this flexural model to the previous SIGHT model...56

Table 4.4: How a hot emplacement would affect petroleum maturity .............60

Table A1.1: Seismic surveys used in this thesis. ...................................... 77

Table A1.2: Exploration and research wells used in this thesis. .....................78

Table A2.1: Available data for time-depth correlation at well U1351..............79

Table A2.2: Available data for time-depth correlation at well U1352 ...............80 


\section{Nomenclature}

This document is a Masters thesis prepared for Victoria University of Wellington. At this time, there are few regulations concerning writing style so the final format is left to the author with regard to reference style, figure placement and other conventions. Therefore, where university regulations are absent, this document follows the conventions set out in the instructions to authors for the New Zealand Journal of Geology and Geophysics (Mellanby 2013). Guidance for discipline-specific terminology is taken from the word list of the American Geophysical Union (Byerly 2010).

The lithostratigraphic nomenclature used here (Section 2.3) is from Carter (1988). The regional unconformity which has previously been called the

Marshall Paraconformity (Carter et al. 1974) is here referrred to as the Marshall Unconformity (Carter 1988; Field \& Browne 1989) due to recognition that it does not fit the criteria for a paraconformity. The naming conventions used in this thesis for sequence stratigraphic units is set out in section 3.2.3 and compared to other works in Fig. 2.6. Where seismic lines are shown, they use a zero-phase, positive-polarity wavelet convention as disseminated by the Society of Exploration Geophysicists 


\section{Introduction}

The eastern margin of the South Island of New Zealand evolved from a post-rift to passive margin in the Neogene Period. During this time, tectonic uplift formed the Southern Alps to the west, which eroded and fed sediment to giant progrades that grew eastward across the continental shelf. Part of this eastern margin is the Otago continental shelf. The shelf has a proven petroleum system and many prospective areas for exploration. Our understanding of the evolution of the progrades is critical to petroleum models in this region (Funnell et al. 1996), yet our knowledge of the detailed stratigraphic architecture and the geometry of these units is limited.

Seismic transects show that the Otago Shelf was uplifted, possibly by a buoyant load under the lithosphere. The uplifted area also has several geophysical anomalies: a positive gravity anomaly, surface volcanics, a high surface heat flow, high mantle-helium ratios, a highly reflective region in the lower crust, and a lowvelocity zone in the lithosphere. The volcano, uplift, and anomalies may all have a common cause: an upwelling of asthenosphere in the mid-Miocene (Godfrey et al. 2001; Hoernle et al. 2006). If an upwelling did occur it would greatly enhance petroleum maturity in the area (Funnell et al. 1996).

\subsection{Motivation for this thesis}

The Neogene Period was an important time in the history of the Canterbury Basin, but little seismic stratigraphy has been conducted for the southern and offshore portions of the basin for this period. Most published work has focused on the central parts of the basin where the ODP (Ocean Drilling Project) and IODP (Integrated Ocean Drilling Project) wells are located (Field \& Browne 1989; Fulthorpe \& Carter 1989; Browne \& Naish 2003; Lu et al. 2003; Osterberg 2006; Carter 2007). Petroleum exploration has covered the entire basin, but has largely targeted the Palaeocene and older intervals where potential source and reservoir 
rocks have been encountered. This leaves a gap in our knowledge of the Neogene Period in the southern portion of the basin.

The Neogene interval is critical to evaluating the basin's petroleum potential because it comprises the overburden and hence is a major factor in achieving maturity within the basin's source rock units. Greater knowledge of the interval will better define the critical moment for petroleum generation, improve basin models, and constrain timings for structural and volcanic events. This thesis uses new well data to correlate key Neogene horizons across the study area. The results are the first maps of these horizons for the southern section of the basin, offering a new understanding of key influences and timing constraints.

The second part of this thesis uses these results as input to a 3D plate flexure model, allowing investigation into the history of uplift under the Dunedin Volcano. The uplift history may support the hypothesis that an upwelling of asthenosphere occurred under Dunedin. This would help explain the anomalies in the area and point toward enhanced petroleum generation potential in nearby source rocks.

\subsection{Project Aims}

The primary objectives of this research are to:

1. Produce depth structure maps of several Neogene horizons on the Otago continental Shelf.

2. Use these horizons to produce 3D plate flexural models related to the uplift history around the Dunedin Volcanic Centre.

For the first objective, newly available well and seismic data are used to map Neogene stratigraphic horizons across the Otago Shelf. The maps produced will extend our knowledge of Neogene geology on the shelf. Specifically they will

provide insight into the timing and extent of the overburden interval, timing of 
structural events and faults, and allow closer investigation into uplift in the Dunedin area.

For the second objective, the afore-mentioned maps are used to make the first 3D model of flexure history around the volcanic centre. The model tests different scenarios, showing which parameters can or cannot explain the observed uplift history within the assumptions of the model. The results have implications for plate makeup, the nature of the uplift, regional heat flow, and petroleum prospectivity.

\subsection{Study Area}

The study area is a portion of the continental shelf (shown in light blue in Fig. 1.1) on the east coast of the South Island, New Zealand. The area covers the continental shelf from the well Takapu-1A in the south and west $\left(46^{\circ} 09^{\prime} 39.39^{\prime} ' \mathrm{~S}, 170^{\circ} 26^{\prime} 7.34^{\prime} ' \mathrm{E}\right)$, to ODP-Site 1119 in the north and east $\left(44^{\circ} 45^{\prime} 19.92^{\prime} ' \mathrm{~S}, 172^{\circ} 23^{\prime} 35.88^{\prime}\right.$ ' E). The area is part of the broader Canterbury Basin, an intracontinental rift and subsequent sag basin (Mogg 2010) which covers more than $40,000 \mathrm{~km}^{2}$. Cretaceous-Pleistocene sediment is thicker than 5 $\mathrm{km}$ in some parts of the basin (Sutherland \& Browne 2003). 


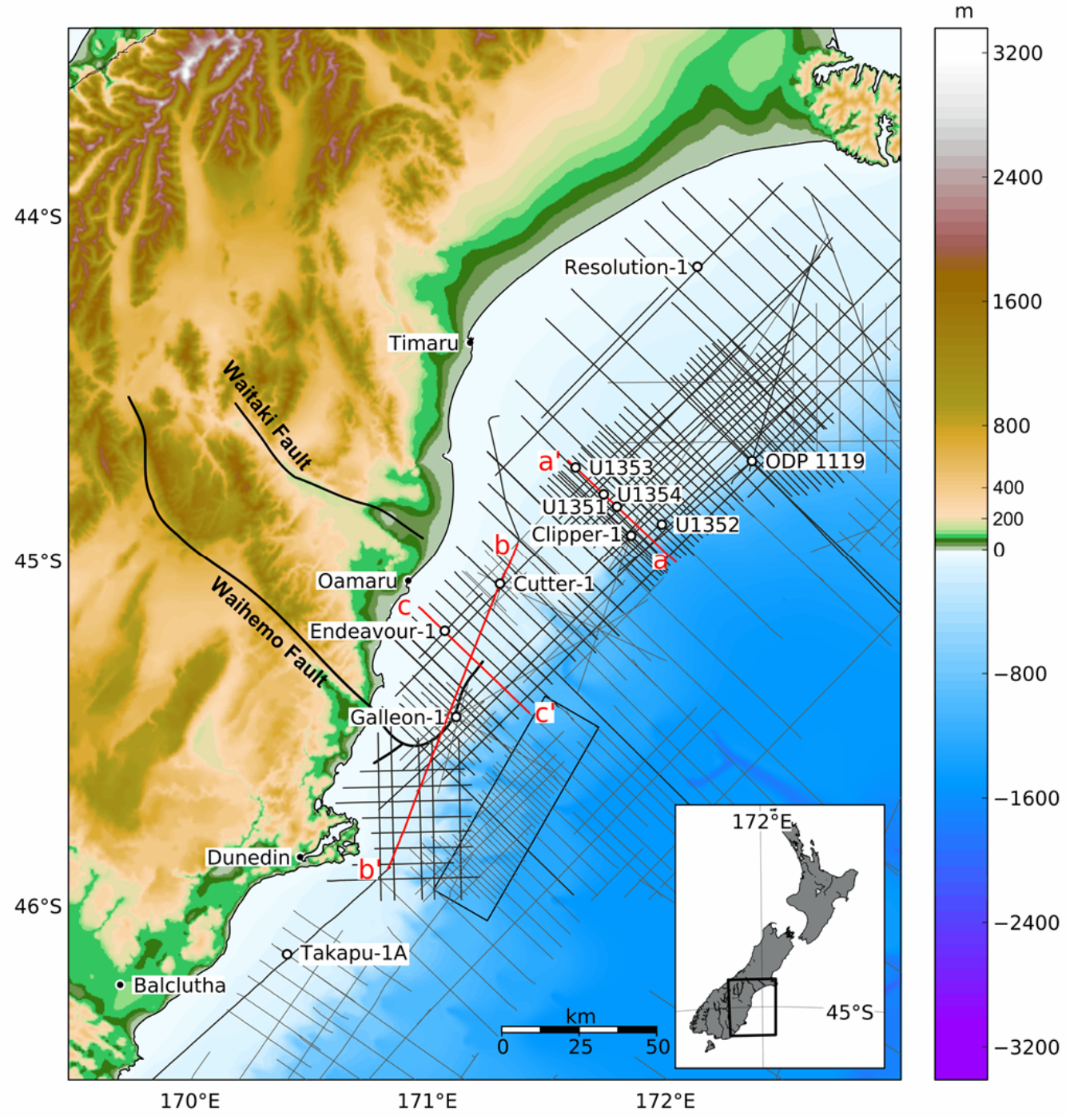

Fig. 1.1: Map of the study area showing 2D and 3D seismic data used in this thesis. The colours indicate elevation compared to mean sea level and labelled black lines show selected faults which were active during the Neogene. Black lines mark primary 2D seismic data, grey lines are secondary 2D seismic, labels indicate wells and place-names, and the rectangular area east of Dunedin marks a 3D seismic survey (the WAKA 3D survey). Transects for Chapter 3 are shown as red lines for Fig. 3.5, Fig. 3.6, Fig. 3.4 respectively.

The Quaternary interval within the basin is an excellent example of a passive margin influenced by high rates of sediment influx and along-shelf currents. In the geological record these influences are manifested as sedimentary drifts in waters of intermediate depth (c. 200-2000 m)(Fulthorpe \& Carter 1991). The basin had high rates of sediment supply in the Neogene after the development and erosion of 
the nearby Southern Alps, which results in a seismic record of high-frequency depositional cycles (Lu 2004).

Both research and industry data sets have been collected within the study area. In 2010-2011, the basin was the focus of the Integrated Ocean Drilling Project (IODP)'s Expedition 317, which drilled four research wells to complement an existing Ocean Drilling Project (ODP) well (Expedition 181, Site 1119). One of the IODP holes (Site U1352) reached almost $2 \mathrm{~km}$ in depth, and because of the level of recent paleontological dating, it has been a key well for correlation purposes. It offers new data to constrain the sequence stratigraphy of the basin, especially in the upper slope.

Companies have undertaken petroleum exploration in this area for more than 50 years. The first offshore well, Endeavour-1, was drilled in 1970. The basin shows promising petroleum potential, with a gas condensate discovery and several petroleum shows. There are currently five offshore petroleum wells and five research wells. Petroleum exploration is on-going with several companies actively exploring in 2014, including drilling of the Caravel-1 well.

Seismic coverage of the offshore Canterbury Basin is modest, with more than 10,000 km of 2D seismic lines acquired from 1966 to present (Mogg et al. 2008). The first 3D survey, the Waka 3D, became publicly available in late 2012 and forms a major part of the source material for this thesis. The University of Texas acquired a high-frequency 2D seismic survey, EW00-01, in 2000. This survey is notable because it targeted depths shallower than $2 \mathrm{~km}$, in contrast to industry seismic surveys that target deeper intervals. The EW00-01 data concerns the area around the ODP 1119 well and covers the area subsequently drilled by the IODP wells in the central section of the basin.

A series of petroleum companies and authors have interpreted the basin's seismic data but few looked at the Neogene interval of the southern Canterbury Basin. Most interpretations focused either on the central basin ( $\mathrm{Lu}$ et al. 2003; Lu 
2004; Carter 2007) or intervals that are older (Mound \& Pratt 1984; Spicer 1986; Perry 1991; Haskell 2000; Hart 2004; Austral Pacific Energy Ltd 2006; Tap Oil Ltd 2006; Mogg 2007; AWE New Zealand Ltd 2010; Constable \& Crookbain 2011; New Zealand Oil and Gas Ltd 2012) or younger (Brown et al. 1988; Browne \& Naish 2003; Osterberg 2006; Gorman et al. 2013) than the Neogene. This leaves a gap in our knowledge of the Neogene interval of the southern portion of the Canterbury Basin. 


\section{Geological Setting}

\subsection{Canterbury Basin}

The study area forms part of the offshore Canterbury Basin (as described in Section 1.3). The Canterbury Basin (Fig. 2.1) extends east from the Southern Alps, under the onshore Canterbury Plains, and includes the adjacent shelf edge and beyond to c. $174^{\circ} 50^{\prime} \mathrm{E}$. It is bounded to the north by Kaikoura and to the south by the Miocene volcanics that form the Otago Peninsula (Brown et al. 1988; Field \& Browne 1989). This chapter provides a summary of the geological background of the basin.

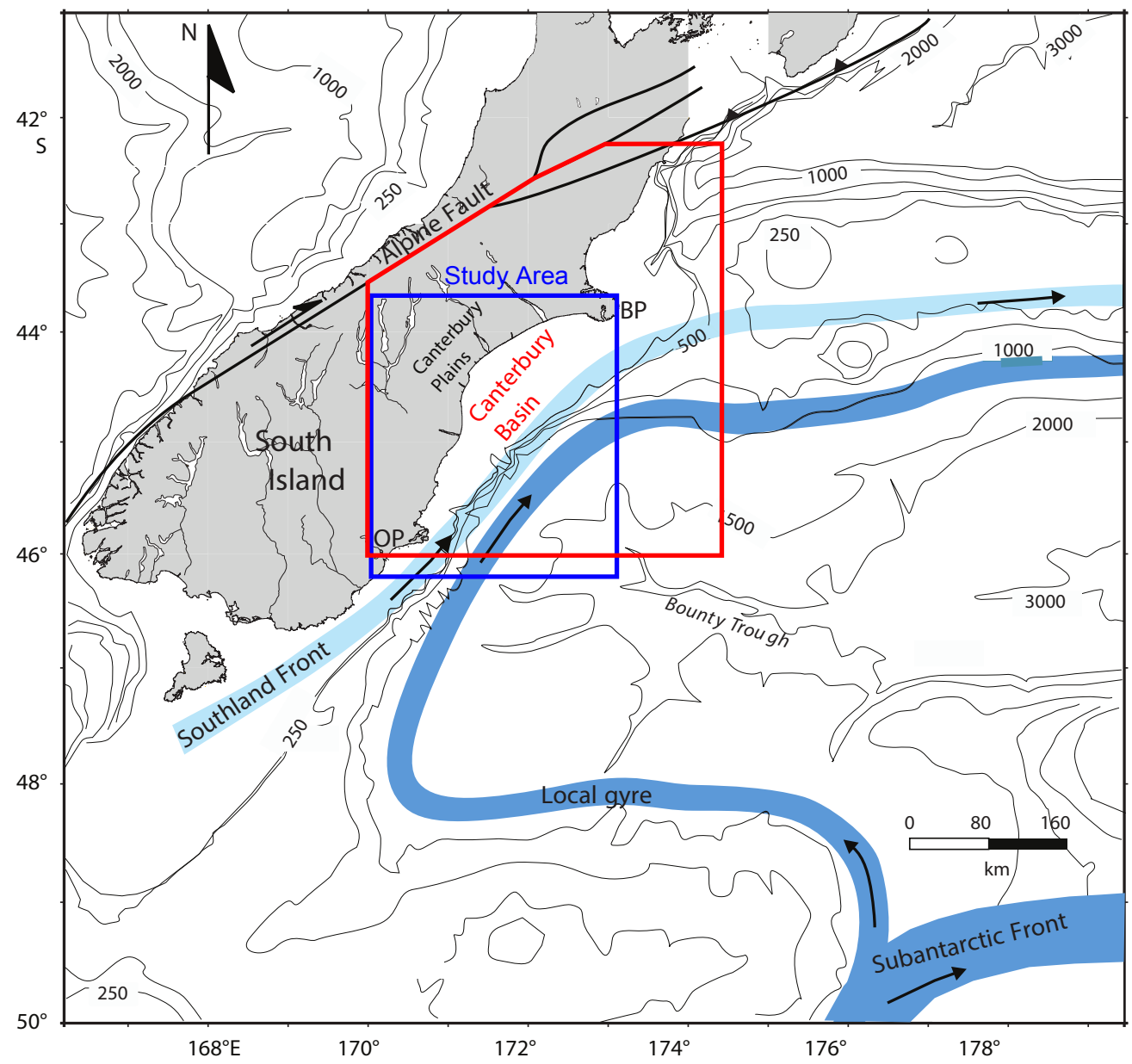

Fig. 2.1: Location map showing features and currents east of the South Island, New Zealand. The Canterbury Basin is marked with a red polygon and the study area is the blue rectangle. The Otago Peninsula is labelled OP, and Banks Peninsula as BP. Major currents are marked in blue and the Alpine Fault is marked with an arrow indicating slip direction. This figure is modified from Fulthorpe et al. (2011). 


\subsection{Tectonic Setting}

The Canterbury Basin forms part of the continental block of Zealandia (CB in Fig. 2.2). Regional tectonics proceeded through three main tectonostratigraphic phases since the Cretaceous Period: rifting, passive margin, and plate boundary convergence (Cande \& Kent 1995; Sutherland 1995).

Rifting began between 105-90 Ma and is associated with the separation of New Zealand from Australia and the greater Gondwana continent (Mayes et al. 1990). Cessation of the rift phase was followed by a passive margin phase from around $60 \mathrm{Ma}$ to $25 \mathrm{Ma}$ (Fig. 2.2, plates 1-2). At $33.7 \mathrm{Ma}$, the Pacific sector of the southern ocean fully opened and thermohaline circulation developed, including the deep western boundary current (DWBC). The new current flow caused a New Zealand-wide hiatus of up to $12 \mathrm{Ma}$, which is recognised in the sedimentary record as the Marshall Unconformity (Fulthorpe et al. 1996). This forms a distinct basin-wide horizon that separates transgressive sediments below the surface from regressive sediments above it.

The basin remained a passive margin until convergence between the Australian and Pacific plate commenced around 20 Ma (Cande \& Stock 2004). In the South Island convergence was accommodated by the Alpine Fault: a large strike-slip fault running down the western side of the South Island (Adams 1979; Tippett \& Kamp 1993a; Walcott 1998; King et al. 1999; King 2000b). Movement on this fault transformed the shape of the continental fragment (Fig. 2.2, plates 3-6), with more than $500 \mathrm{~km}$ of right-lateral displacement recorded since its inception (Kamp 1987). Between $15 \mathrm{Ma}$ and 2.6 Ma the pole shifted southwest (Stock \& Molnar 1982; Sutherland 1995), causing a growing component of convergence on the Alpine Fault that resulted in uplift of the Southern Alps, along with increased erosion, and sediment supply (Lu 2004). 


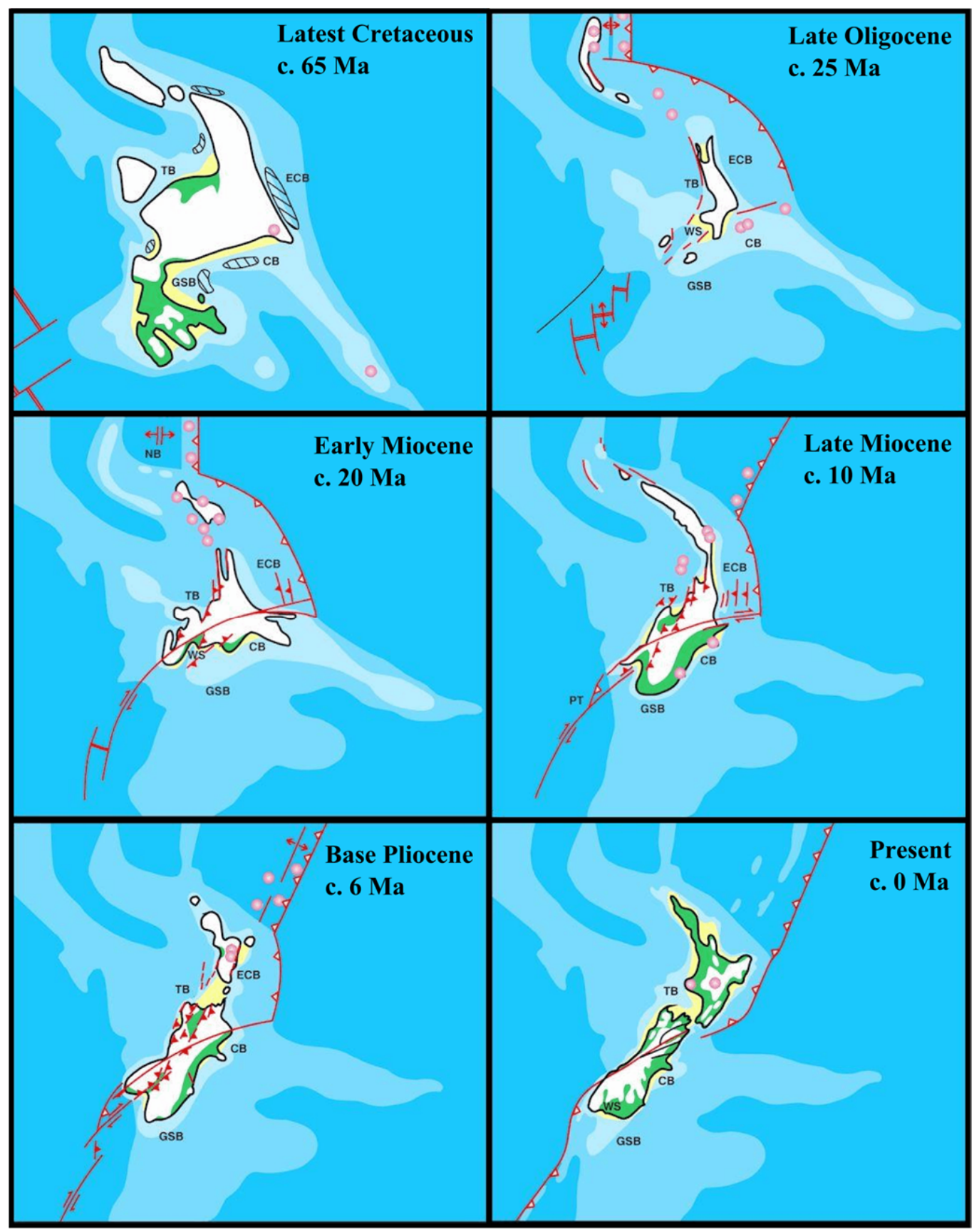

Fig. 2.2: New Zealand tectonic plate reconstructions from (after King et al. 1999; King 2000a). The Canterbury Basin is denoted by the letter CB, Great South Basin by GSB, Taranaki Basin by TB, and the East Coast Basin by ECB. The bold line depicts the paleocoastline and the pink circles indicate active volcanism. White colouring is terrestrial non-deposition, yellow is marginal marine sand-dominated facies, pale bluegrey is the shelf, mid-blue is the slope or rise, and dark blue is deep ocean. Faults, subduction zones, and seafloor spreading centres are shown in red. 


\subsubsection{Physiographic Setting}

The Canterbury Basin has a complex physiographic setting. Sediment has the ability to cross the entire basin from west to east. Beginning with sediment input from erosion of the Southern Alps in the west, then crossing the Canterbury Plains, shelf, and slope where it interacts with many oceanographic features, until it ultimately deposits into the Bounty Trough and Bounty Fan.

In the modern physiography, large braided rivers transport substantial volumes of sediment from the Southern Alps onto the Canterbury Plains and shelf. This amounts to $50,000 \mathrm{~km}^{3}$ in the last 5 Ma (Herzer 1981; Browne \& Naish 2003). The sediment has built a wide continental shelf up to c. $90 \mathrm{~km}$ wide in the northern portion of the Canterbury Basin. The northward-directed Southland Front runs along the shelf, orthogonal to the sediment supply from the west (Fig. 2.1). This alongshore current has an average speed of $6 \mathrm{~cm} / \mathrm{s}$ (Herzer 1979; Carter et al. 1999) and moves 400,000-700,000 $\mathrm{m}^{3}$ of sediment northward each year (Kirk \& Tierney 1978).

Partly as a result of alongshore drift, the shelf has a gentler slope to the north at c. $2^{\circ}$, compared to $>5^{\circ}$ to the south. The current creates large sediment drifts at slope depths with erosional moats ( $\mathrm{Lu}$ et al. 2003). Other notable features include current reworking, sediment sourced from the south (Fulthorpe et al. 2011), and unconformities that indicate current scoured platforms (Fulthorpe et al. 1996). These depositional features suggest that similar currents have been operating since 30 Ma. Seismic interpretation is made difficult by heterogeneous depositional features caused by changes in currents and current regimes.

In the lower bathymetric portions of the slope is a local gyre of the Subantarctic Front, which forms the leading edge of the Antarctic Circumpolar Current. This influences sedimentation to $900 \mathrm{~m}$ water depth. Numerous canyons also cut the shelf in the south, with many of them intercepting sediment 
transported from rivers or alongshore currents and transporting those sediments eastward to the Bounty Trough.

\subsubsection{Alpine Fault}

The Alpine Fault is a remarkably linear feature that can be traced along the length of the South Island and marks the plate boundary between the Pacific and Australian plates. It is a large strike-slip fault that connects a subduction zone to the north and a reverse fault zone to the south with opposite convergence directions. More than $200 \mathrm{~km}$ of right-lateral displacement has been recorded since $6 \mathrm{Ma}$ but total shortening across the Alpine Fault is only $90 \mathrm{~km}$ (Walcott 1998). The extent of strike-slip movement is so great that the basement terranes of New Zealand are distinctly curved as they approach the Alpine Fault, displaying a geometry consistent with dextral shear (Sutherland 1999). With time, the plate boundary experienced an increasing degree of convergence that built the Southern Alps, a mountain range as high as $3700 \mathrm{~m}$ in elevation that runs down the west coast of the South Island. Erosion of the Southern Alps is a major sediment supply to the Canterbury Basin.

Research on the Alpine Fault has been intensive. The history of movement on the Alpine Fault along with the timing and extent of bending of New Zealand basement terranes has been one of the most widely debated subjects in the literature on New Zealand geology (Sutherland 1999). There are a wide range of proposed initiation times for Alpine Fault movement, and later for uplift of the Southern Alps. Initiation of strike-slip motions occurred around either $100 \mathrm{Ma}$ (Wellman \& Cooper 1971), 45 Ma (Sutherland 1999), 30 Ma (Carter \& Norris 1976), 25-23 Ma (Cooper et al. 1987; Kamp 1987; Adams \& Cooper 1996; Lebrun et al. 2003), or 20 Ma (Cande \& Stock 2004). Estimates for uplift of the Southern Alps similarly vary between around 15 Ma (Carter et al. 1991), 11 Ma (Cande \& 
Stock 2004), 10-8 Ma (Carter \& Norris 1976; Norris et al. 1978; Adams 1979), or 8-5 Ma (Tippett \& Kamp 1993a; Batt et al. 2000).

Presently the Alpine Fault accommodates c. $35.5 \mathrm{~mm} / \mathrm{yr}$ of parallel movement and $10 \mathrm{~mm} / \mathrm{yr}$ of perpendicular movement between the Australian and Pacific plates (DeMets et al. 1994; Leitner et al. 2001). Movement varies along its length, becoming almost pure strike-slip at its northern and southern ends (Sutherland 1999). Tectonic reconstructions of the central Alpine Fault reveal that the maximum convergence rate occurs north of the Fox Glacier area (Lu 2004), where exhumation rates have been measured at up to c. $10 \mathrm{~mm} / \mathrm{yr}$ (Tippett \& Kamp 1993b).
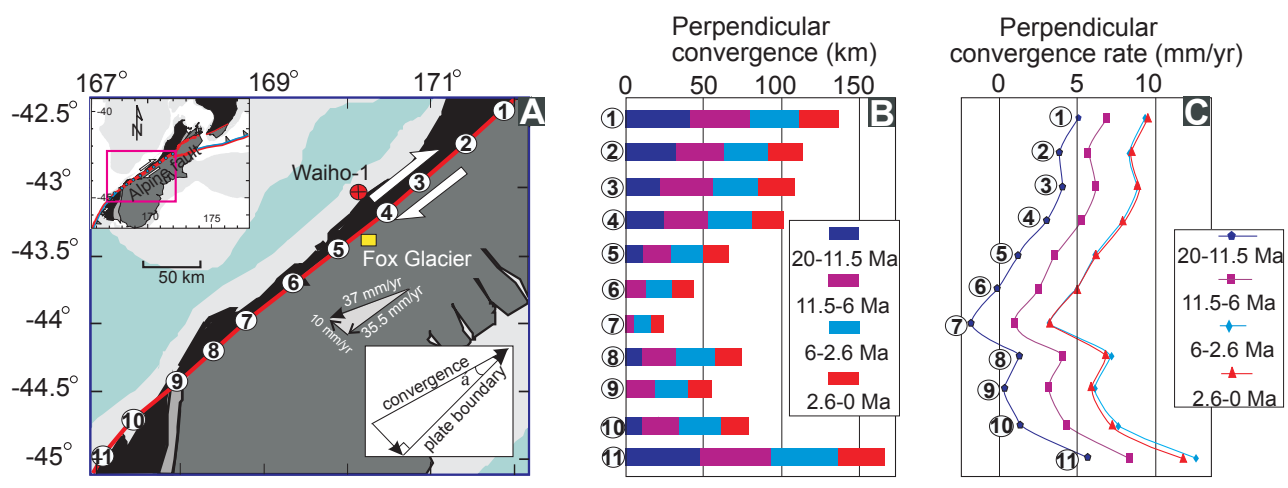

Fig. 2.3: Convergence differs along the strike of the Alpine Fault. A, The positions of 11 sites along the fault. B, The total convergence perpendicular to the fault (middle). C, The associated rate of perpendicular convergence (right) of these sites over four time intervals. This figure is modified from $\mathrm{Lu}(2004)$.

Terrigenous sediment began to accumulate offshore as early as $20 \mathrm{Ma}$ (Fulthorpe et al. 2011) near the IODP Expedition 317 wells. From 11-0 Ma, sedimentation is strongly correlated with convergence on the fault, suggesting that erosion of the Southern Alps is the main factor in sedimentation (Lu, 2004). Convergence on the Alpine Fault varies with position (Fig. 2.3) (Lu 2004). It may be possible to use this to predict sediment thickness from 11 Ma to present. If so, sediment should be thinnest in the southern part of the basin, and thickest in the central basin. However, the link between sediment supply and deposition may be 
complicated by along-shelf currents, volcanic uplift, plate flexure, canyons, and other processes.

\subsubsection{Subsidence}

For the most part, the subsidence in the basin follows an exponentially decreasing curve, which is typical of a post-rift basin. Fig. 2.4 demonstrates this using the subsidence curve for the Clipper-1 exploration well ( $\mathrm{Lu} \mathrm{2004),} \mathrm{which} \mathrm{is} \mathrm{located} \mathrm{in}$ the central basin. A major divergence from the trend occurs from c. 50 Ma to 35 Ma when there is a slight inflection. The curve switches to an increasingly rapid subsidence trend as early as $20 \mathrm{Ma}$, increasing toward the present day, which is caused by a shift in tectonics from post-rift to convergent.

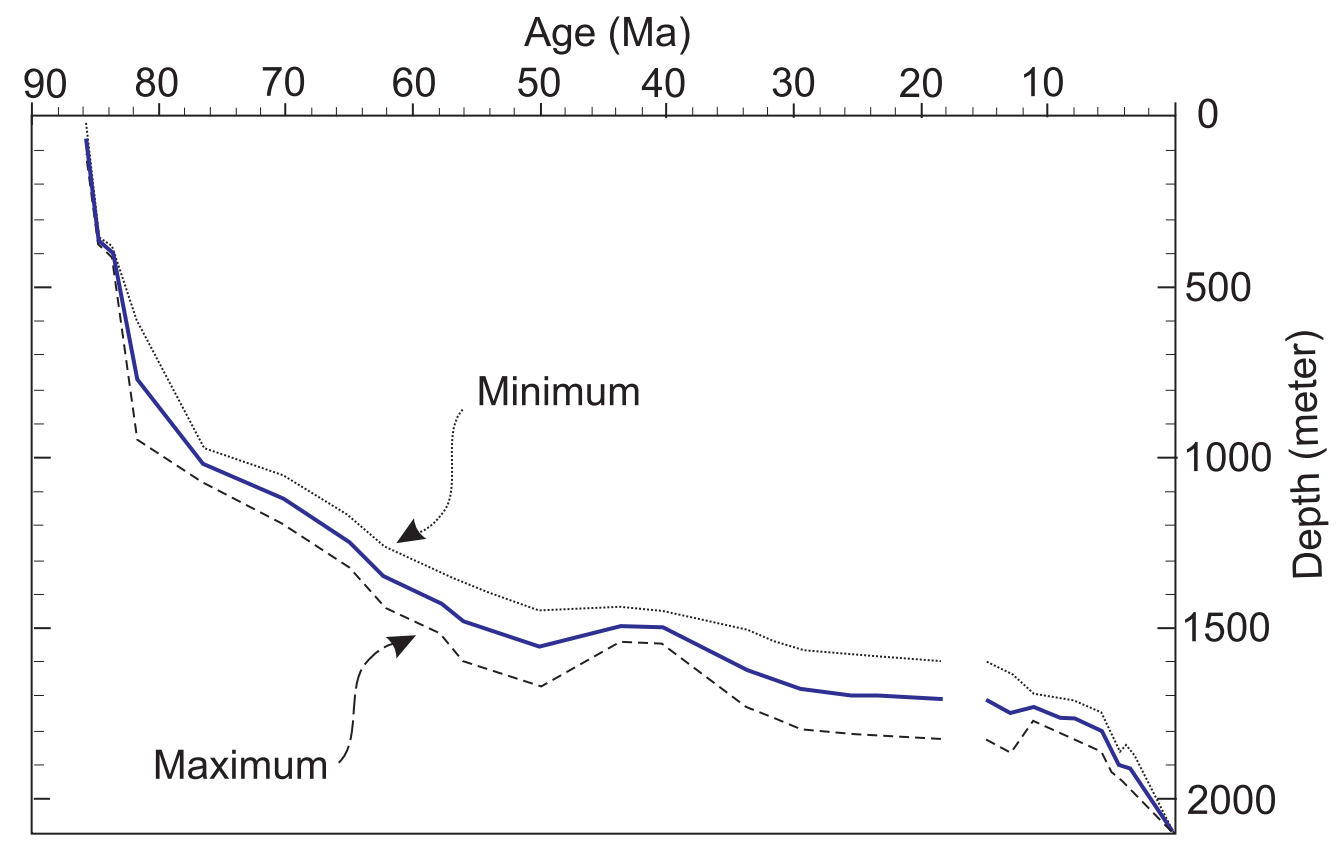

Fig. 2.4: Tectonic subsidence curves for the Clipper-1 exploration well. Figure modified from $\mathrm{Lu}(2004)$.

\subsection{Sedimentation}

Sediments in the Canterbury Basin can be divided into several tectonostratigraphic groups based on the broad tectonic evolution of the region: rifted basin, passive margin, and active plate boundary. Fig. 2.5 illustrates these groups with a schematic of the basin's large-scale stratigraphy (after Carter 
1988). During the rifted basin phase, pre-rift and syn-rift sediment were deposited. The pre-rift basement terranes formed as part of the Gondwana succession by sediments and volcanics deposited during the Permian to Early Cretaceous and their metamorphosed equivalents. The Syn-rift Matakea Group (of Carter 1988) was deposited in Cretaceous grabens and half-grabens during rifting. They comprise predominantly coarse clastic sediments, which include nonmarine breccia-conglomerates and thick immature coal measure sequences (Carter et al. 1994).

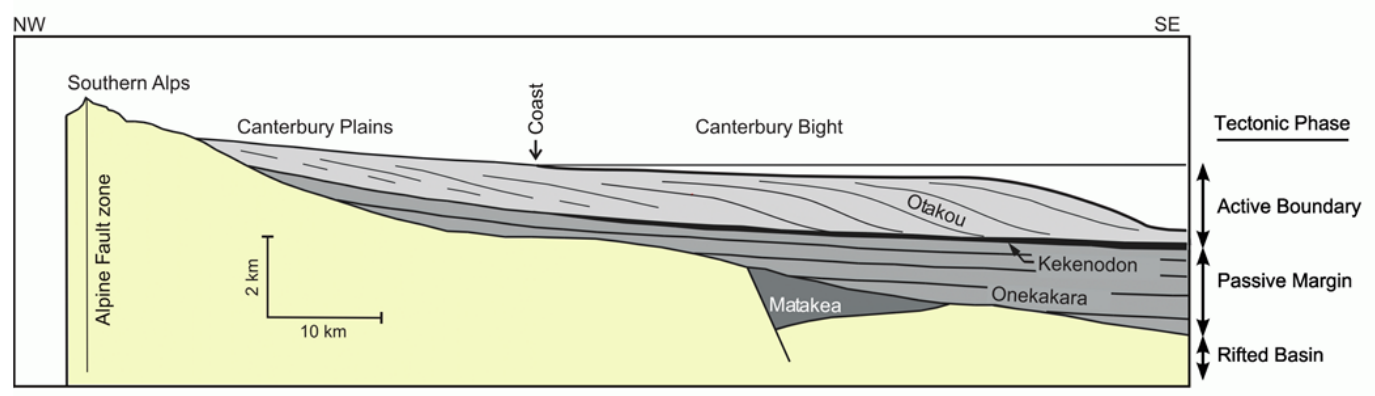

Fig. 2.5: Schematic large-scale stratigraphy of the Canterbury Basin after Carter (1988), figure modified from (Fulthorpe et al. 2011).

After rifting, the basin became a passive margin. Post-rift thermal subsidence led to the deposition of the Onekakara Group (of Carter 1988) during the Late Cretaceous to Early Oligocene. Mainly fine-grained siliciclastic and carbonate mudstones and limestones were deposited during this time, with less abundant sandstones and volcanics (Carter 1988). A regional unconformity called the Marshall Unconformity (or the Marshall Paraconformity of Carter et al. (1974)) was possibly caused by a change to a dominantly regressive sedimentary regime (Fulthorpe et al. 1996). This unconformity was followed by deposition of basinwide bioclastic limestone and calcareous sandstones units within the Kekenodon Group.

A regressive phase followed, during which the Otakou Group (of Carter 1988) was deposited. This group consists of a prograding wedge comprised mainly of marine mudstone and sandstone, but with minor limestone and non-marine 
deposits including lignite (Forsyth 2001). Deposition within the Otakou Group had two major phases. During the first phase, from c. 20 Ma to 11.3 Ma, sedimentation around the IODP wells was not associated with convergence on the Alpine Fault. During second phase, from 11.3-0 Ma, sedimentation was strongly correlated with plate convergence, which implies that sedimentation was more strongly driven by erosion on the Southern Alps (Lu 2004).

\subsection{Seismic Stratigraphy}

Previous seismic stratigraphy has focused either on time periods outside the Neogene Period or on locations in the central basin, leaving a gap in our knowledge of the Neogene interval of the southern portion of the Canterbury Basin.

Petroleum exploration has generated numerous seismic interpretation reports (Fig. 2.6) that focus on the Eocene or older intervals of the basin, which contain the source and reservoir rocks (Mound \& Pratt 1984; Spicer 1986; Perry 1991; Haskell 2000; Hart 2004; Austral Pacific Energy Ltd 2006; Tap Oil Ltd 2006; Mogg 2007; AWE New Zealand Ltd 2010; Constable \& Crookbain 2011; New Zealand Oil and Gas Ltd 2012). Most of the reports use 2D seismic data but Mogg (2010) has interpreted the first 3D data in the area, the Waka 3D, with a focus on the Oligocene and earlier horizons.

Academic stratigraphy has focused on the area to the north of the study area, where the high-frequency EW00-01 seismic survey and multiple research wells are located ( $\mathrm{Lu}$ et al. 2003; Carter 2007), or on the earlier Quaternary interval (Brown et al. 1988; Browne \& Naish 2003; Osterberg 2006; Gorman et al. 2013). The exception to this is an older study (Fulthorpe \& Carter 1989) which could not successfully apply global sea level curves to the basin due to complex stratigraphy and a lack of well and biostratigraphic data. 


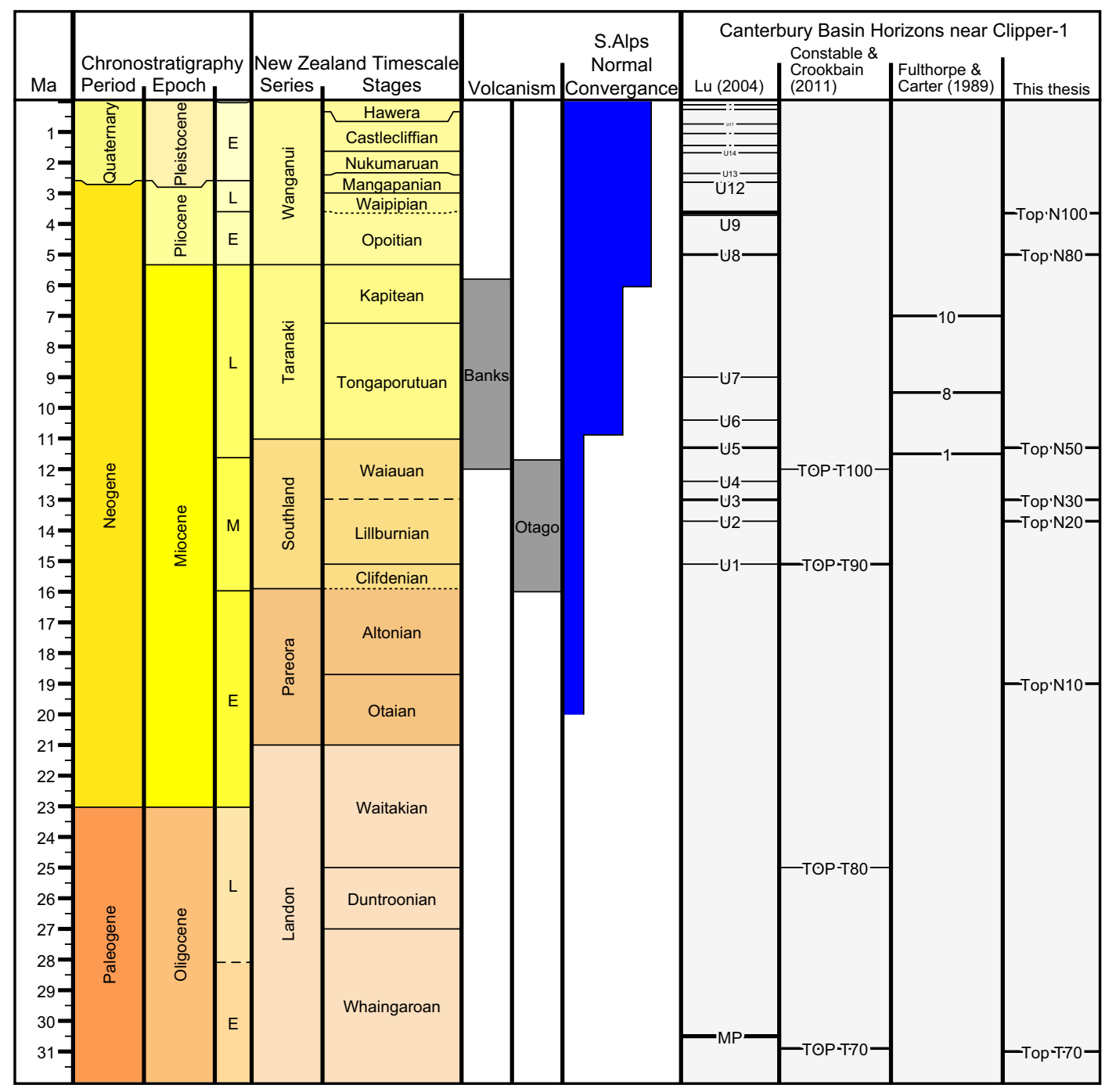

Fig. 2.6: Canterbury Basin horizons and events. From left to right: New Zealand stratigraphic timescale; sequence boundaries from this thesis, Lu (2004), Fulthorpe \& Carter (1989), and Constable \& Crookbain (2011); dates of selected major volcanism events; and oblique convergence on the Southern Alps (Cande \& Stock 2004; Fulthorpe et al. 2011) from 0 (left) to $150 \mathrm{~mm} / \mathrm{yr}$. 
This leaves a gap in our knowledge of the Neogene interval in the southern basin, despite important Neogene events such as the Dunedin uplift, canyon and drift development, and overburden emplacement.

\subsection{Volcanism}

There are numerous volcanic centres in the Canterbury Basin. They span a wide age range from the mid-Cretaceous to the Pliocene and are widely distributed throughout the Canterbury and Great South basins (Field \& Browne 1989; Timm et al. 2010). For the purpose of this thesis, the relevant volcanics are the late Cenozoic intraplate basalts in the Dunedin area, shown in Fig. 2.7.

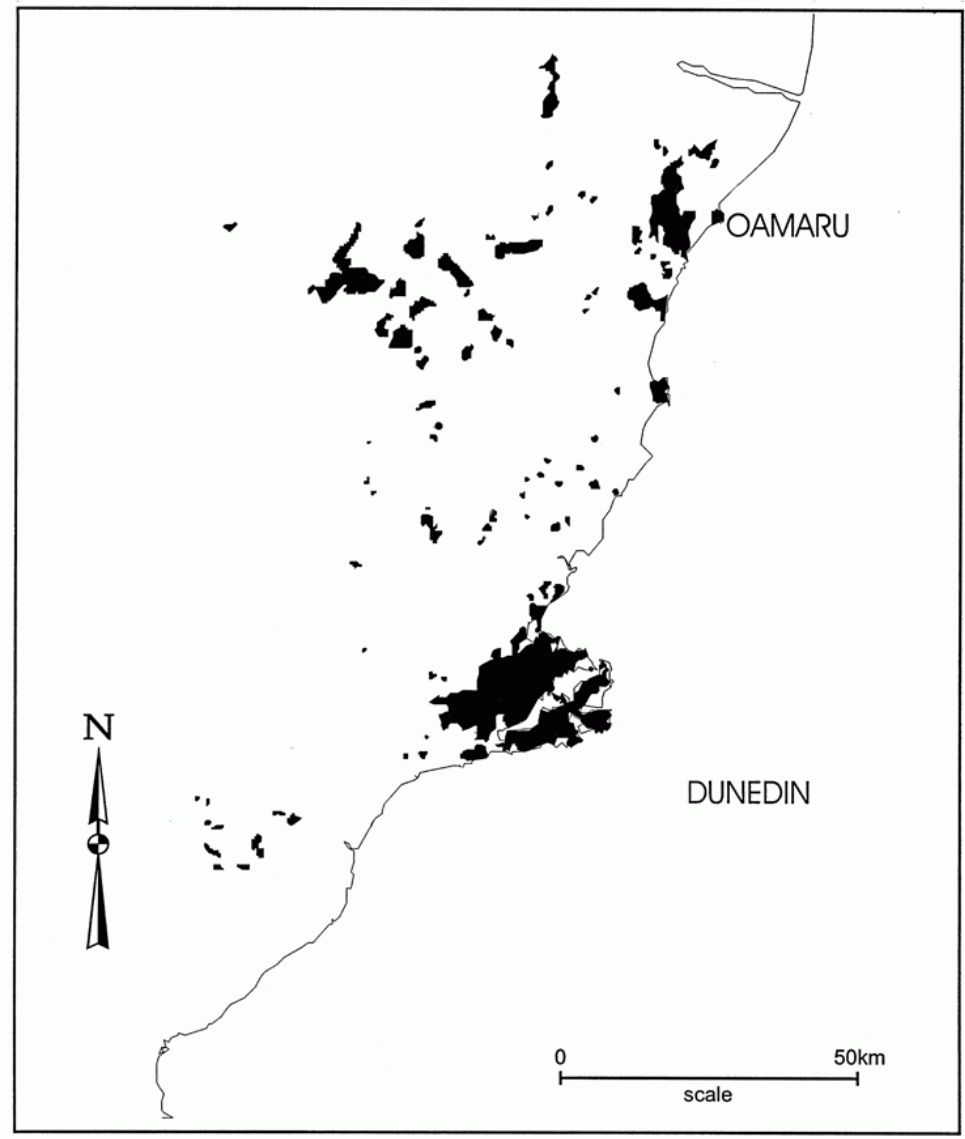

Fig. 2.7: Late Cenozoic basalts in the onshore Dunedin area (black), modified from Hoke et al. (2000). 
The main phase of intraplate basaltic volcanism occurred during the middle Miocene, forming two major shield volcanoes: the Bank Peninsula and Dunedin volcanics (Fig. 2.6). The Dunedin Volcano was active for c. 4 Ma between 16.0 and 10.1 Ma with surrounding vents and flows erupting between 23 and $9 \mathrm{Ma}$ (Hoernle et al. 2006; Coombs et al. 2008). The Bank Peninsula volcanoes were active from $>12$ to c. 7 Ma (Timm et al. 2010). During this time they discharged large volumes of basaltic magma (c. $1600 \mathrm{~km}^{3}$ at Banks Peninsula and c. $600 \mathrm{~km}^{3}$ at Dunedin) making them the most voluminous Neogene intraplate volcanoes in New Zealand (Timm et al. 2010). The cessation of volcanic activity at these locations has been linked to the start of convergence on the Alpine Fault (Hoke et al. 2000).

The origin of the middle Miocene volcanic centres on the South Island is debated. They are intraplate basaltic volcanoes presumed to be too far removed from the active plate margin to be subduction-related (Hoke et al. 2000). Researchers have advanced several hypotheses to explain them. These include relative movement of Zealandia over a linear mantle region of upwelling asthenosphere (Adams 1981; Farrar \& Dixon 1984), a fossil plume head (Weaver et al. 1994; Storey et al. 1999), hotspots (Hoernle et al. 2006), melting of the lower lithosphere due to a hotter than normal asthenosphere (Finn et al. 2005; Panter et al. 2006; Sprung et al. 2007), and lithospheric removal (Hoernle et al. 2006; Timm et al. 2010). The debate over their origin has roots in conflicting evidence. The volcanism ranges from large to small-scale and has no progression in age and location. There is also conflicting evidence from heat flow, mantlehelium (Godfrey et al. 2001), and geochemistry (Timm et al. 2010).

\subsection{Geophysical Anomalies near Dunedin Region}

Several geophysical anomalies are present around Dunedin that suggest the injection of buoyant melts and heat into the mantle and crust (Godfrey et al. 
2001). These observations include high heat flow (Funnell et al. 1996; Cook et al. 1999), helium gas anomalies (Hoke et al. 2000), positive isostatic gravity anomalies (Reilly 1972), volcanism and evidence of an upwarped region of low seismic wave-speeds beneath the Dunedin Volcano (Fig. 2.8). Seismic lines approaching Dunedin (Fig. 3.6) show that an Oligocene limestone horizon has been uplifted and multiple horizons truncate onto it.

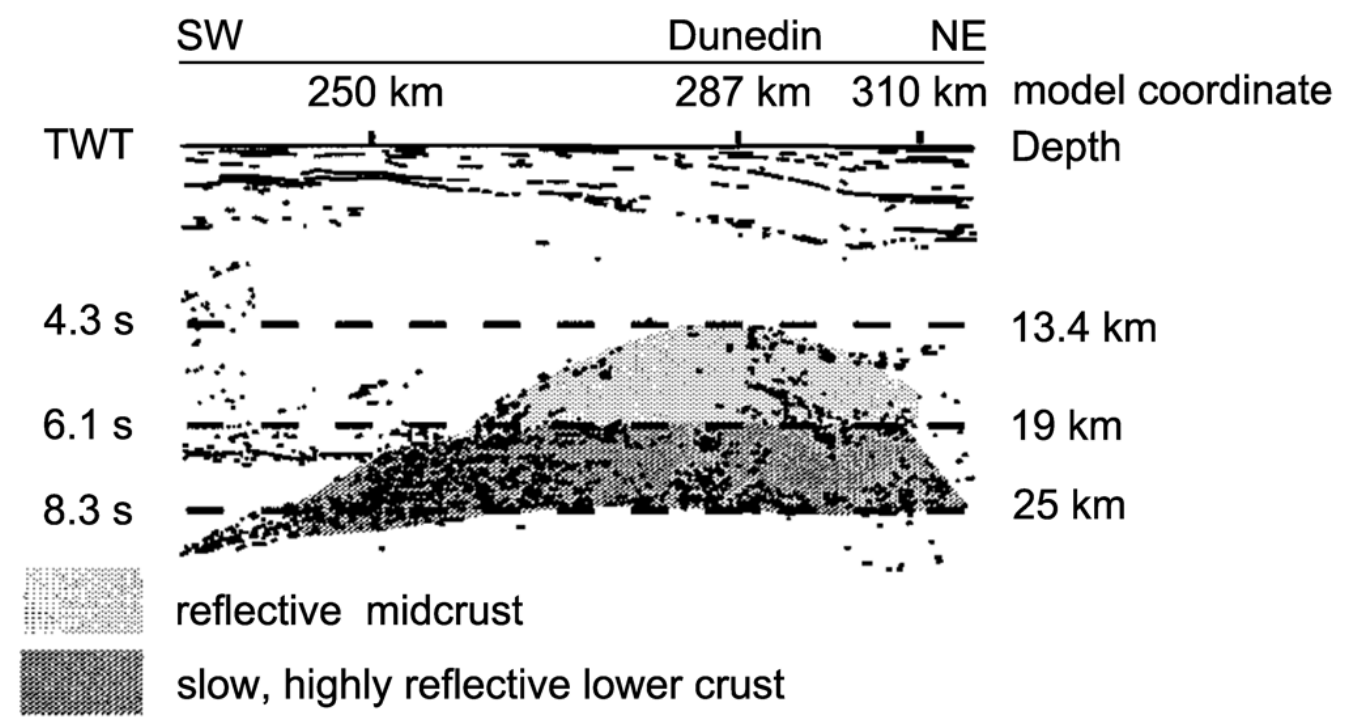

Fig. 2.8: Seismic data has revealed crustal anomalies beneath Otago that may represent a hot fluid-rich region. Figure modified from Godfrey et al. (2001).

The cause of these anomalies and the uplifted limestone layers has been a subject of debate. Godfrey et al. (2001) propose that the anomalies may be caused by a hot body emplaced beneath and into the lower crust, the heat of which is just reaching the surface today. If so, this would mean that petroleum source rock near Dunedin would have enhanced maturity, potentially extending the petroleum producing area (Funnell et al. 1996). In this model, the lowvelocity zone is caused by a hot, fluid-rich region in the crust and mantle. In addition to the high heat flow and low-velocity zone, this model explains the high helium ratios and the positive isostatic gravity anomaly. A variation of this hypothesis is supported by Hoernle et al. (2006) as a cause of the Dunedin 
volcanics because it explains why volcanism was restricted to one region over such a long period of time. This hot and buoyant body may have also uplifted the regional limestone horizon. This possibility was tested by Godfrey et al. (2001) using a 2D flexure model and the uplift was found to be consistent with the model.

The link between the apparent uplift and the Dunedin volcanics has been questioned for two reasons (Mortimer et al. 2002). First, the uplift could be an artefact of the intersection of the 2D seismic transect and paleoshorelines, in which case it would disappear when viewed on different seismic transects. Secondly, Miocene uplift was widespread throughout onshore Otago, not just restricted to the doming around the Dunedin Volcano. Mortimer et al. (2002) noted that this issue needs to be more closely examined using shallow seismic datasets. The next chapter does this using a widespread set of $2 \mathrm{D}$ and $3 \mathrm{D}$ seismic data.

\subsection{Petroleum Potential}

The Canterbury Basin is a petroleum basin with a long history of petroleum exploration dating back to 1914 when the first onshore well was drilled. Since that time, a number of onshore and offshore wells have been drilled, many to basement, targeting predominately Cretaceous source rocks and reservoirs of Cretaceous to Tertiary age. All the elements of the petroleum system are present in the basin: the source, reservoir, seal, overburden, and trap. The elements are illustrated in the petroleum systems diagram in Fig. 2.9 for Galleon-1, which produced a gas-condensate show (Wilson 1985).

Source rocks have been a key risk in the basin, with BP Shell Aquitaine and Todd Petroleum Development Limited attributing failure to find commercial hydrocarbon accumulations to a lack of sufficiently mature source beds (Sutherland \& Browne 2003). The primary source rocks are Late and mid- 
Cretaceous coal measures, but there are prospective Palaeocene-age black shales (Mogg 2008). The mid-Cretaceous source rocks may have the greatest maturity and hydrocarbon potential and have been proven at Clipper-1 and Galleon-1 (Hawkes et al. 1985; Wilson 1985). They were deposited in a syn-rift environment that was mostly terrestrial and paralic and are mostly limited to grabens, while the Late Cretaceous source rocks represent transgressive sediments and have a wider distribution in the basin (Sykes \& Funnell 2002). The latter were deposited in a post-rift environment that was predominantly fluvial and paralic (Killops et al. 1997). The Palaeocene-age black shales are potential source rock and have the distinction of being the most oil-prone, but they may lack maturity (Sykes \& Funnell 2002).

Reservoirs include mid Cretaceous and Late Cretaceous terrestrial and transgressive marine sandstones. Late Cretaceous sandstones of the post-rift sequence are a proven reservoir, however they are restricted to the west of the Canterbury Basin (Mogg 2010). They could include coastal plain sands as drilled by Endeavour-1, marginal marine sandstones as drilled as Galleon-1 and Resolution-1, or potential Late Cretaceous turbidite sands on the contemporary slope. The reservoirs in Clipper-1 were mid-Cretaceous sandstone with good porosity and limited permeability (Doust 2006).

Late Cretaceous marine shales and early Tertiary marine mudstones provide seals for both Late Cretaceous and mid-Cretaceous reservoirs (Haskell 2000). These provide an effective seal but volcanics frequently create a risk of seal breach. Most explored trap styles in the basin are Palaeocene doming and folding or Eocene drape of strata over igneous intrusions (Mogg 2010). The potential for other plays exists, as many traps are present in the basin such as tilted fault blocks, channel sands, graben fill, and turbidite fans.

The thick prograding Otakou Group of the Neogene provides overburden. The timing and location of the overburden could prove important in petroleum 
modelling because it determines the critical moment when the source rocks reached the required burial depth for generation and expulsion of hydrocarbons.

The critical moment is the point in time when generation, migration, and accumulation come together to preserve the most hydrocarbons in a petroleum system (Magoon \& Dow 1994). For Galleon-1 this point was in the Oligocene to Recent, when overburden reached a thickness conducive for generation and migration into existing traps. Throughout the basin, the critical moment could vary based on numerous factors including the timing of overburden emplacement, uplift history, heat flow gradient, and nearby volcanic emplacement.

This thesis improves models of the petroleum system in two ways. First, it produces maps of key horizons in the Neogene sequence, improving our knowledge of the timing of overburden emplacement. This allows petroleum models to constrain the timing of oil expulsion because the timing of overburden emplacement has a dominant effect on maturation history for the Canterbury Basin (Funnell et al. 1996). Second, this thesis investigates a model where a hot and buoyant body caused the uplift around Dunedin. The increased heat from the hot body would result in enhanced source rock maturity around offshore Dunedin, and extend the kitchen area by bringing source rocks into the oil production window (Funnell et al. 1996). 


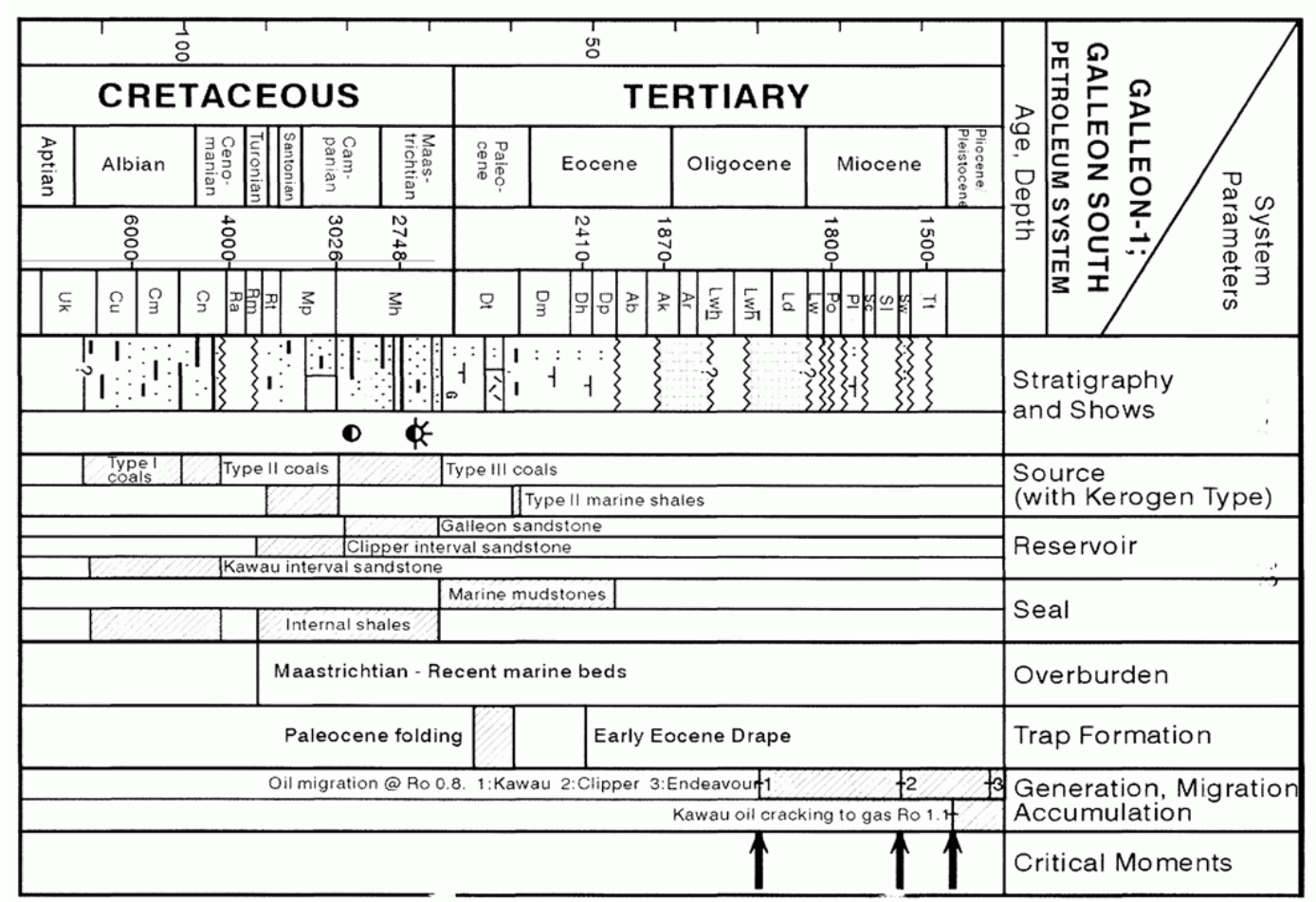

Fig. 2.9: A petroleum systems diagram for the Galleon-1 exploration well. Figure from Haskell (2000). 



\section{The Neogene Seismic Stratigraphy of the Otago Shelf}

\subsection{Introduction}

This chapter covers the use of the latest well and seismic data to map Neogene age horizons across the Otago Shelf. Six Neogene horizons are mapped across the shelf from the IODP wells in the north to the Otago Peninsula in the south. Depth conversion and gridding has been used to convert the seismic horizons from two-way time into depth horizons. From these, a series of structure contour and isopach maps have been produced that document the evolution of the Neogene interval. The results show the evolution of the overburden and provide age constraints to structural events in the basin such as the Endeavour High and uplift on the Otago Shelf. Generated maps will also be used for a flexural model of the uplift, presented in the next chapter.

\subsection{Data Set}

The data used in this thesis are a combination of research and industry open-file data. The research data include 2D seismic lines and wells with associated logs, biostratigraphy, and well tops. The industry data are open file and include 3D seismic surveys as well as further 2D seismic lines and wells with associated logs, biostratigraphy, and well tops made available through a series of Petroleum Reports (PRs) on the New Zealand Petroleum and Minerals website, www.nzpam.govt.nz.

\subsubsection{Seismic Data}

Seismic data for the Canterbury Basin were acquired from 1966 to present, and include more than $12,000 \mathrm{~km}$ of $2 \mathrm{D}$ seismic data (Samuel 2011) and $1000 \mathrm{~km}^{2}$ of 
3D seismic data. These data cover the continental shelf and extend some distance beyond the slope.

The petroleum exploration industry generated most of the seismic data, with notable exceptions being the high resolution EW00-01 multi-channel survey targeting the Neogene (Lu et al. 2003) and the SIGHT96 transects targeting the deep structure of the Pacific-Australian plate boundary (Sutherland et al. 2012).

The quality and level of data processing varies greatly and includes data from a modern 3D survey to 1970's 2D seismic data with poorly digitised locations. Surveys were not used if they were made redundant by a newer survey, could not be reliably tied to modern data, used sub-optimal processing, or used incorrect navigation. The seismic surveys used are shown in Fig. 1.1 and listed in the Table A1.1.

To ensure that the timing and phase of the seismic data was consistent, misties and inconsistent phases were identified and corrected. The EW00-01 survey shot by the research vessel Maurice Ewing was used as a reference survey, because it is relatively new data (acquired in 2000) and processed to a uniform and high standard. Other surveys were matched progressively outward from the Ewing data. To identify mis-ties in seismic lines, different seismic data were compared at the distinct Oligocene limestone reflection (Marshall Unconformity) and bulkshifted where necessary.

\subsubsection{Wells}

Six offshore industry wells have been drilled on the continental shelf since 1970: Endeavour-1, Resolution-1, Clipper-1, Galleon-1, Takapu-1A, and Cutter-1 (for detail see Table A1.2). These industry wells have targeted the Cretaceous to Palaeogene intervals. Although logging was undertaken for the Neogene interval in all of these wells, the only consistent log is gamma, which lacks response because 
it was logged through casing. This prevented well correlation using downhole logs across the basin.

In 1998 and 2010 respectively, the Ocean Drilling Project (ODP) and the Integrated Ocean Drilling Project (IODP) drilled five wells. These provide essential biostratigraphic well control within the study area because they focused on the Pleistocene and Neogene intervals, providing the best biostratigraphic control for shallower sediments (Expedition 317 Scientists 2011).

Unfortunately, all wells are located on the continental shelf or slope (Fig. 1.1). The nearest well control for present-day water depths greater than $350 \mathrm{~m}$ is hundreds of kilometres away, either on the Chatham Rise or in the Great South Basin. This means that any horizon beyond the slope must be correlated from the shelf, which means passing through many drifts, canyons, migration-caused misties, and facies changes, leading to unavoidable uncertainty. Anadarko Petroleum Corporation have drilled the Caravel-1 well in the Waka 3D boundaries in the first quarter of 2014 but the results of this well remain confidential. Once this information is released publicly, it should provide biostratigraphy and well control that will drastically improve Neogene interpretation beyond the shelf.

\subsubsection{Well Tops and Biostratigraphy}

The main wells used in this study are Clipper-1 and the four IODP wells. The biostratigraphy used for Clipper-1 was sourced from Griffin (2009), for IODPU1352 from unpublished data by GNS Science (M. Crundwell, pers. comm. 2013), and for the remaining IODP wells from Expedition 317 Scientists (2011). Well-top data comes from Expedition 317 Scientists (2011) and Lu (2004) (called U2-U10 in the data source).

The well tops and biostratigraphy are of good quality; for example, Clipper-1 biostratigraphy underwent only minor revision since initial drilling. The agreement between the core wells is visible on Fig. 3.5 where in general they 
correlate well. Unfortunately, these wells are restricted to the central shelf, which introduces uncertainty in the southern basin and the slope.

\subsection{Method}

\subsubsection{Well Correlation}

A well correlation attempts to use well logs, seismic data, and biostratigraphy to correlate features among wells. This can provide better constraints for seismic interpretation, which in turn leads to more accurate output maps.

In this thesis, well correlation for the Neogene interval is not possible due to lack of data. Log data is sparse in this interval because previous exploration had no commercial interest in Neogene targets. The logs that were run usually consist of a gamma log from a cased hole, and so there is very little character to the log. Logs in the IODP research wells are more complete, but only cover a small area of the basin. Even among the IODP wells the Neogene sequence boundaries did not have a distinct character on the available logs.

\subsubsection{Well to Seismic Ties}

Well-to-depth ties are important because they provide the critical links from physical logs to seismic data. However, they must be performed with care because they are a significant source of uncertainty in the final maps. The depth tie for Clipper-1 used publicly available check-shot data from the well-completion report by Hawkes et al. (1985). The IODP U1351 and U1352 wells were more difficult to tie because they lack a vertical seismic profile, instead a mixture of Canterbury Basin data sources were used, specifically core data from Polat (2012), synthetic seismograms from Polat (2012), and a regionally established depth-to-time relationship from Brusova (2011). Where possible core observations were incorporated, followed by synthetic seismograms, or if these were not available, a regional time-depth relationship (Table A2.1 and Table A2.2). The divergence 
among depth functions is shown in Fig. 3.1 and reveals a divergence of up to $8 \%$ (increasing with depth). This gives us some idea of the uncertainty arising from this step.

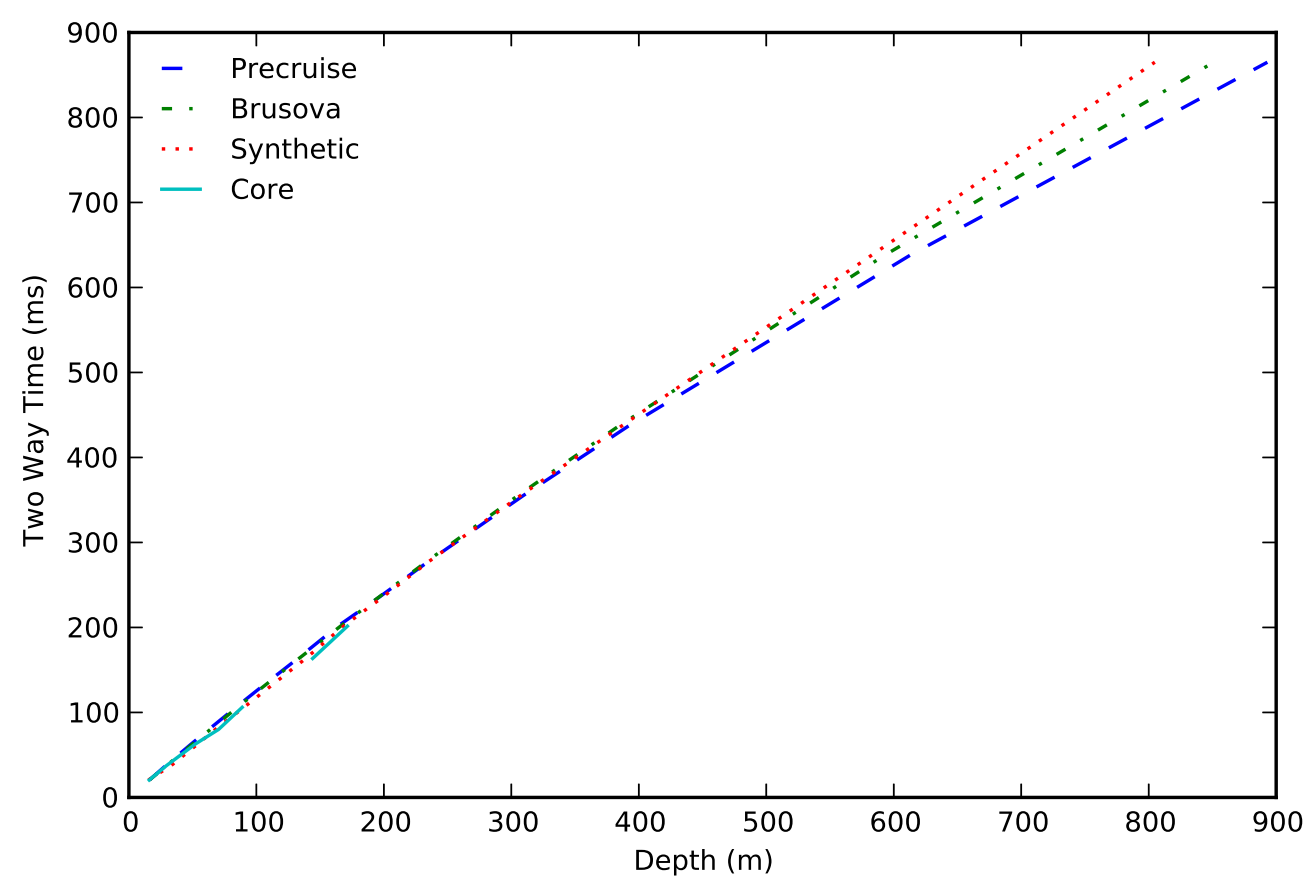

Fig. 3.1: Comparing functions to convert time and depth. Time is in seismic two-way time and depth is in metres below sea floor for the IODP U1351 well. The functions shown are Expedition 317 Scientists (2011) pre-cruise depth function (dashed line), Brusova (2011)'s depth function for Offshore Canterbury (dash dot line), Polat (2012)'s core observations (solid line) and synthetic seismogram (dotted line). The divergence between depth functions is be up to c. $8 \%$.

\subsubsection{Interpretation Methods}

Standard seismic interpretation was carried out as detailed in Sheriff \& Geldart (1995). The following steps were taken for regional seismic interpretation:

(1) Well tops were loaded in Petrel (Schlumberger Ltd 2013) and time-todepth conversion established (as described in section 3.3.1).

(2) Horizons that could be regionally correlated were identified and defined (as described in section 3.3.4).

(3) Seismic correlation was carried out between Clipper-1 and IODP wells using the down-dip seismic line EW00-01-66 shown in Fig. 3.5.

(4) Horizons were interpreted on two key transects: a composite line made of SIGHT-96 lines and line EW00-01-66 (Fig. 3.6 and Fig. 3.5). These are illustrated in map view in Fig. 1.1. 
(5) Interpretation progressed on loops of seismic lines. These started over a small area and increased in size until key horizons were interpreted over the shelf.

(6) Infill interpretation was performed on dip lines (trending SE-NW), followed by strike lines (perpendicular to dip lines) until a consistent set of horizons covered the shelf.

(7) Slope transects were constructed which carried interpretation off the shelf and into slope areas.

(8) Interpretation was joined between slope transects to extrapolate key horizons to the slope.

(9) Several iterative stages of quality checking and refinement followed.

(10) Initial isochron and two-way time maps were used to further refine interpretation.

(11) Depth conversion used a basin wide velocity model and allowed construction of depth structure maps and isopach maps.

(12) Final depth structure maps were created within the study area.

(13) Isopach maps were created using the calculated difference between successive structure maps.

\subsubsection{Interpreted Horizons}

Eight horizons were mapped over the southern Canterbury Basin (Fig. 2.6). The Marshall Unconformity was also interpreted regionally as it was a prominent and regionally correlatable surface and because it provides a lower bounding surface to the Neogene succession. Further horizons were selected from Lu (2004) if they were distinct enough to be interpreted regionally. Lu (2004) named these horizons $\mathrm{U} 10, \mathrm{U} 8, \mathrm{U} 5, \mathrm{U} 3, \mathrm{U} 2$, and $\mathrm{U} 1$, but in this thesis they are named Top N100, Top N80, Top N50, Top N30, Top N20, and Top N10 for consistency with Constable \& Crookbain (2011).

Horizon names like U10 refer to unconformity 10, but this nomenclature only has relevance to a particular study area and time interval. To map over a larger region, a naming scheme needs wider relevance. The naming scheme for this thesis uses the letter ' $\mathrm{N}$ ' for Neogene and a number that increases from oldest to youngest horizons. For clarity, Fig. 2.6 compares horizons from this thesis with those from other works. The names are organised so that unconformities have 
similar names to Lu (2004), for example U10 becomes Top N100 and U5 becomes Top N50.

The horizons are defined below according to their age and facies in the central Canterbury Basin (Appendix 3); however their characteristics will change with distance and paleogeographic setting.

\subsubsection{Gridding and Depth Conversion}

Gridding of interpreted horizons was performed in Petrel (Schlumberger Ltd 2013) using the minimum curvature algorithm and a grid resolution of one cell per $100 \mathrm{~m}$. This allowed two-way time horizons to be converted to two-way time maps and highlighted flaws in the interpretation, allowing for iterative refinement.

A velocity model was created to convert maps from two-way time to depth, using a simple time-to-depth equation from (Fulthorpe et al. 2011) which is compared to alternatives in Fig. 3.1. The equation is $\mathrm{Y}=317 \mathrm{X}^{2}+758.3 \mathrm{X}$, where $Y$ is the depth below seafloor in metres and $X$ is the two-way travel time in seconds. This velocity model allows conversion from two-way time grids to depth grids and the difference between depth structure grids was used to create isopach maps.

\subsection{Results and Discussion}

One of the aims of this thesis is to produce depth maps of Neogene seismic horizons. The maps produced here show how the Neogene shelf started before 19 Ma as a deepwater region around structural highs and prograded progressively eastward to create the modern shelf. The isopach maps highlight the wedge of prograding sediment as it moves outwards and is increasingly cut with canyons and mass failures. The results will allow for better back-stripping, improve our ability to model overburden emplacement in petroleum models, and provide better timing for structural events. In particular, the results allow us to put age 
constraints on movement on the Endeavour Fault and uplift around the Otago Peninsula.

The depth maps for seven mapped horizons and modern seafloor are shown in Fig. 3.2 and larger maps can be found in the appendix in Fig. A5.1 to Fig. A5.9. Fig. 3.2c to $3.6 \mathrm{~h}$ show the continental shelf prograding to the east with time. This is especially obvious in the north of the basin where the shelf progrades at a greater rate. At $31 \mathrm{Ma}$ (Fig. 3.2) two structural highs are present and the rest of the mapped area is covered with greater than $1000 \mathrm{~m}$ of water. The first high, to the south, is the Otago Peninsula uplift and to the north is one associated with the Waihemo Fault. These highs are progressively covered with sediment drape as the shelf progrades. The uplift is no longer visible at $13.7 \mathrm{Ma}$ (Fig. 3.2c) and the second high is onlapped and over topped at 3.65 Ma (Fig. 3.2g).

Isopach maps in Fig. 3.3 highlight the changes in depth between mapped horizons. Larger isopach maps can be found in the appendix in Fig. A5.10 to Fig. A5.16. The isopachs must be compared with care because they cover different periods of time and reflect preserved sediment, not deposited sediment. Large changes in depth may reflect either a high sedimentation rate or conversely, a long period of time. A small change in depth may reflect low sedimentation or high erosion.

The first isopach (Fig. 3.3a) covers a highstand interval followed by erosion caused by the Marshall Unconformity. It shows that most preserved sedimentation is far beyond the modern shelf. In the younger isopachs, a thick wedge of prograding sediment is visible, pinching out to the south as it nears the Otago Peninsula. The wedge moves basin-ward with time and is particularly thick in the isopachs after c. $8 \mathrm{Ma}$, which coincides with increased convergence on the Alpine Fault. 


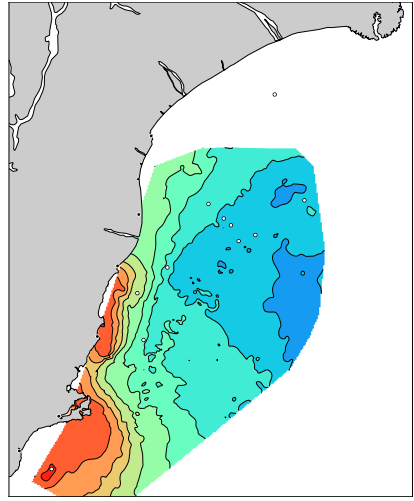

(a) Top T70 - the uplifted horizon (31 Ma)

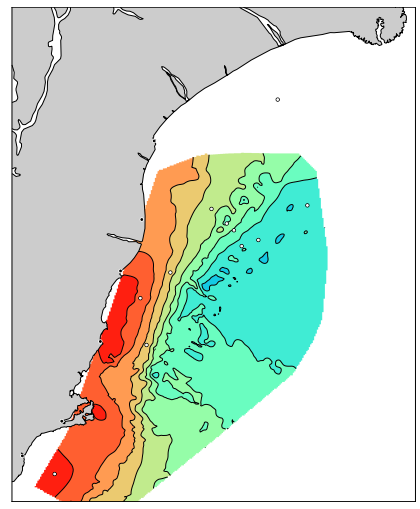

(d) Top N30 (13 Ma)

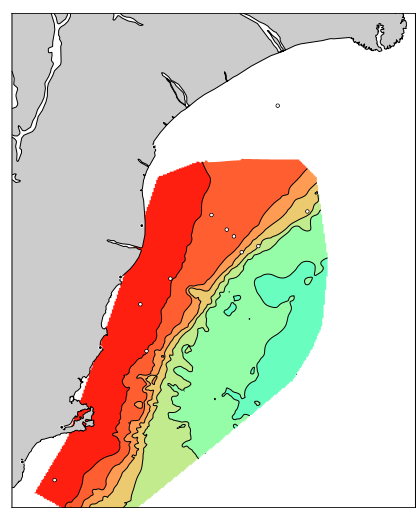

(g) Top N100 (3.65 Ma)

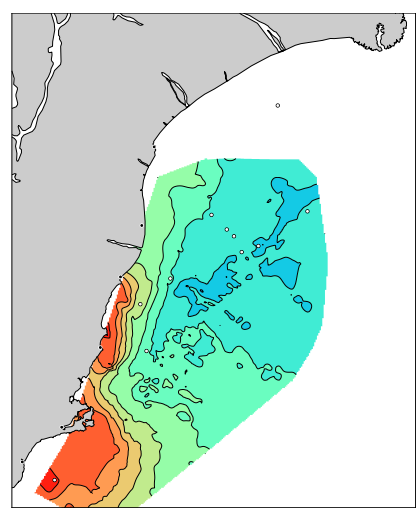

(b) Top N10 (19 Ma)

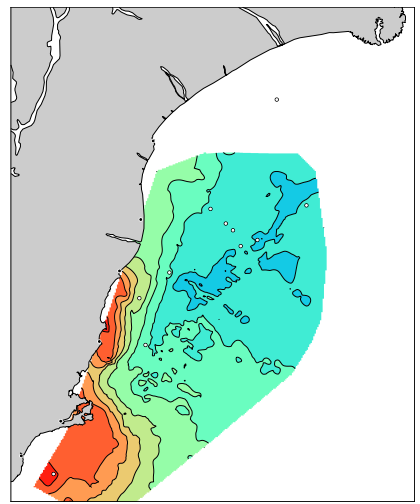

(e) Top N50 (11.3 Ma)

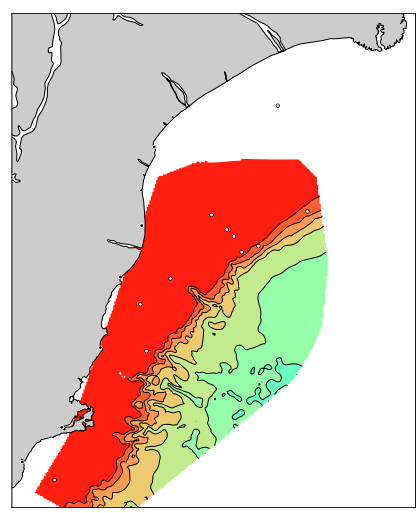

(h) Seafloor

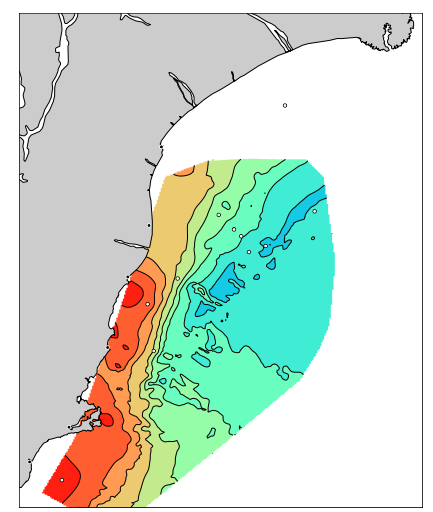

(c) Top N20 (13.7 Ma)

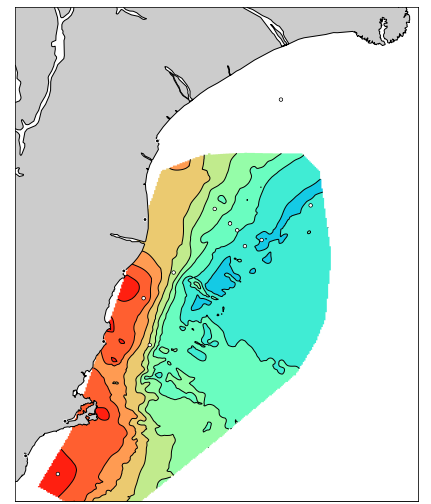

(f) Top N80 (5 Ma)

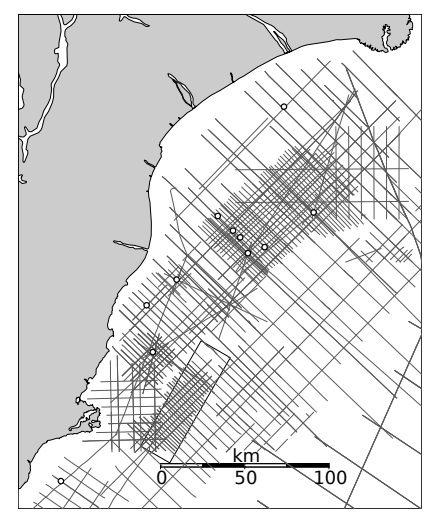

(i) Base map

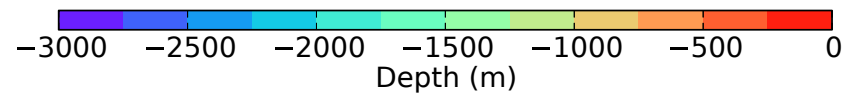

Fig. 3.2: Depth maps for Neogene horizons in the southern Canterbury Basin. Images are orientated to grid north in New Zealand Transverse Mercator projection. The legend shows the depth in metres from mean sea level. Larger images can be found in Appendix 4 . 


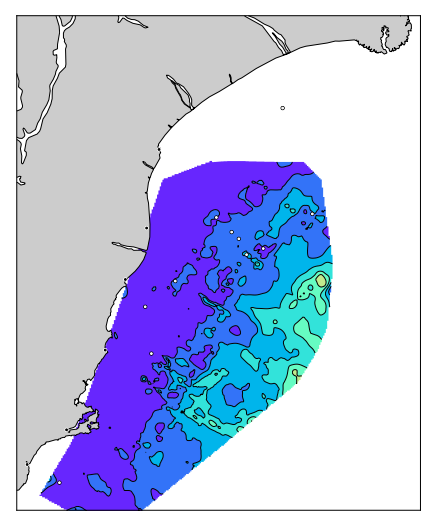

(a) Top N10-Top T70 (31-19 Ma)

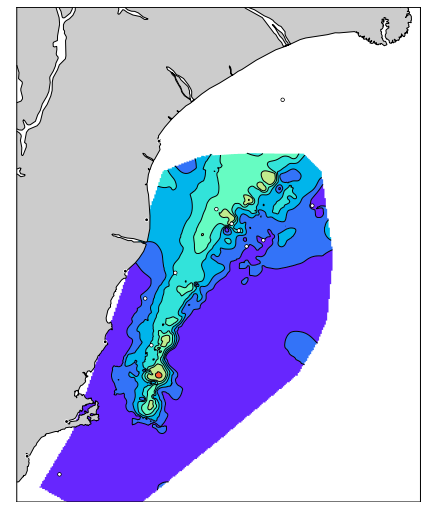

(d) Top N50-Top N30

(13-11.3 Ma)

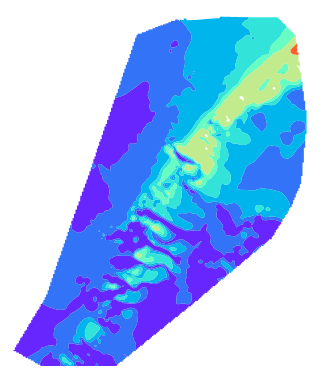

(g) Seafloor -Top N100 (3.65-0 Ma)

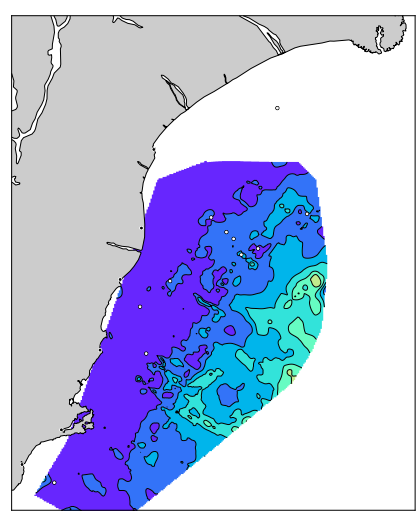

(b) Top N20-Top N10 (19-13.7 Ma)

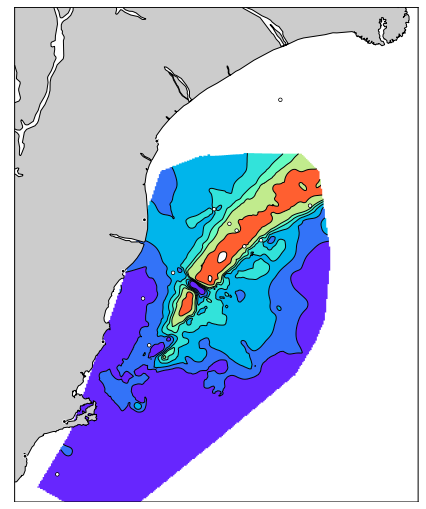

(e) Top N80-Top N50

(11.3-5 Ma)

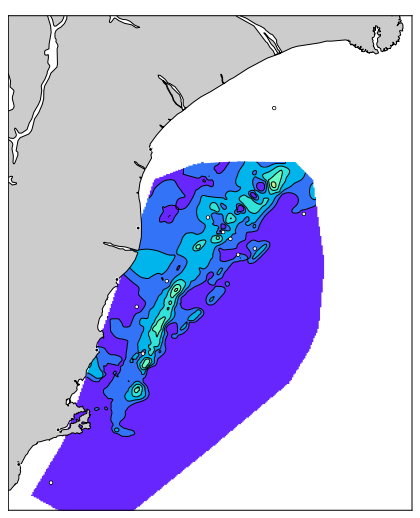

(c) Top N30 - Top N20 (13.7-13 Ma)

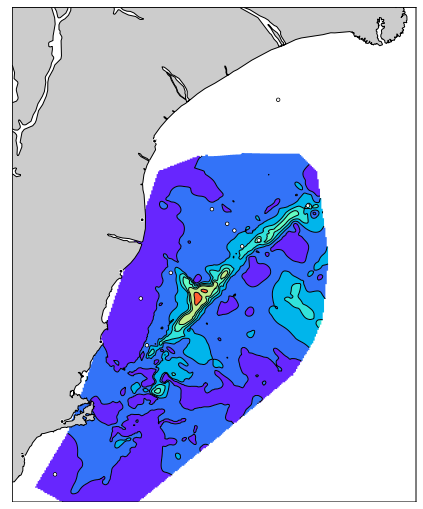

(f) Top N100-Top N80 (5-3.65 Ma)

(h) Base map

Fig. 3.3: Isopach maps for Neogene horizons in the southern Canterbury Basin. The legend shows thickness in metres. Images are orientated to grid north in New Zealand Transverse Mercator projection. Larger images can be found in Appendix 4. 
In the following three isopach maps (Fig. 3.3b-d) there is a thick band that represents a wedge of prograding sediment. In the final three isopach maps covering 5-0 Ma (Fig. 3.3g), depth differences are visible to the northeast of the prograding wedge, in contrast to previous isopach maps. This could be for several reasons, for example it may be the toe of an extremely thick wedge, lack of erosion by succeeding progrades, or a flexural sinking in response to increased convergence on the Alpine Fault.

The most recent isopach (Fig. 3.3g) has a prograding wedge that is cut by canyons. This is especially evident in the southern basin, which has a steeper shelf edge gradient. Seismic evidence indicates that canyons were present in older periods, but these are not visible in the isopachs.

The Neogene horizons can give us improved timing on events in the Canterbury Basin such as the Otago Peninsula uplift and the Endeavour High. Of particular interest is the uplift around the Dunedin Volcano area, which was investigated by Godfrey et al. (2001) with a single horizon and transect. Fig. 3.6 shows this uplift on an interpreted seismic line where the interpreted horizons can be used to establish age constraints on uplift. In the figure, the Top N20 to Top N50 horizons onlap the uplifted limestone of the Top N10 horizon, implying that there was topographic relief prior to the deposition of these units. The Top N80 and Top N100 horizons have no evident onlap, which implies that there was no longer topographic relief and that uplift had ceased. These relationships imply that uplift started after $19 \mathrm{Ma}$ and stopped before 5 Ma.

The relationships between seismic horizons and the Endeavour High can also be used to date movement on the Endeavour Fault (Fig. 3.4). The largest offset on the fault occurs before Top N10 and additional offset occurs between Top N10 and Top N20. This indicates that most offset occurred prior to 19 Ma with additional offset between $19 \mathrm{Ma}$ and $13.7 \mathrm{Ma}$. These dates fall within the range given previously by (Field \& Browne 1993) who reported that onshore evidence 
suggests uplift initiated during the late Oligocene and terminated in the early Miocene.

\subsubsection{Uncertainty}

It should be noted that this method of inferring dates is subject to significant uncertainty. Sources of error in the input data include the dating and time-todepth conversion. Biostratigraphic data is used to date horizons, and during this process implicit errors in the biostratigraphic dating method are inherited (Punyasena et al. 2012). When the four IODP wells and Clipper-1 were compared, the biostratigraphic dates differed by more than $30 \%$, even over distances less than $10 \mathrm{~km}$. Errors in depth conversion arise when using the velocity model to convert depth data to seismic two-way time. In Fig. 3.1 time depth-conversions for this thesis's key wells were found to differ by up to $8 \%$.

The next stage, interpretation, is a highly subjective process prone to biases well known in cognitive psychology and common to all expert judgements (Polson \& Curtis 2010). Expert interpretations usually contradict one other and frequently contradict objective benchmarks. Rankey \& Mitchell (2003) found that net-to-gross prediction by experienced interpreters differed by up to $57 \%$. Bond et al. (2007) found that out of 412 interpretations of a synthetic seismic image, only $21 \%$ interpreted the 'correct' tectonic setting.

This thesis interprets hundreds of kilometres of mostly 2D seismic data with varying quality and poor well control. Even for an expert interpreter, this would be a challenge. The uncertainties are significant and it is certain that in the future improved data will modify the present interpretation. Box and Draper's maxim is especially pertinent here: 'all models are wrong, but some are useful' (Box \& Draper 1987). 


\subsubsection{Future Work}

The scarcity of input well data could be remedied in the future with planned industry drilling in the summer of 2014, which will offer new and pertinent information that would allow the seismic horizons to be updated. Other interesting features are also present that may be worth revisiting. On Fig. 3.6, between Top N10 and Top N20, is a possible mass failure and several small canyons. On both the Endeavour High and the Dunedin uplift, local sequence boundaries are visible. These have little or no age control, but their relative sequence stratigraphy may offer a higher resolution glimpse into the development of these structures.

\subsection{Summary}

Regional seismic mapping has defined the stratigraphic and spatial extents of several Neogene age seismic horizons over an area that has not previously been mapped. The depth maps produced in this thesis show how the Neogene shelf started before $19 \mathrm{Ma}$ as a deepwater region around structural highs and prograded to create the modern shelf. The isopach maps highlight the wedge of prograding sediment as it moves outwards to the east, becoming increasingly eroded by submarine canyons and mass failures. Mapped horizons also provide new age constraints on features of the Endeavour High and the Dunedin uplift. The Early Miocene limestone horizon provides a 3D uplift surface around the Dunedin volcanics, which will form the basis for further modelling presented in the next chapter. 


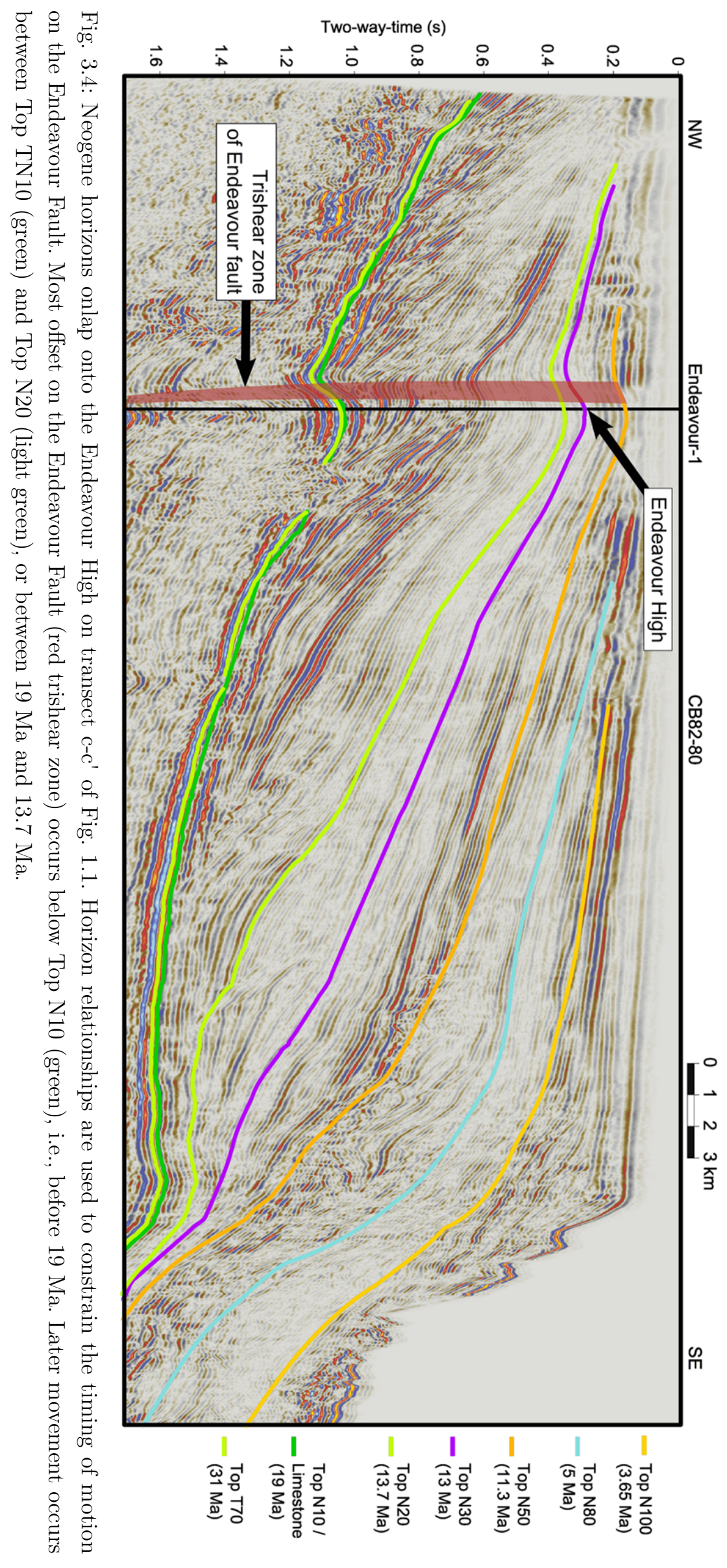




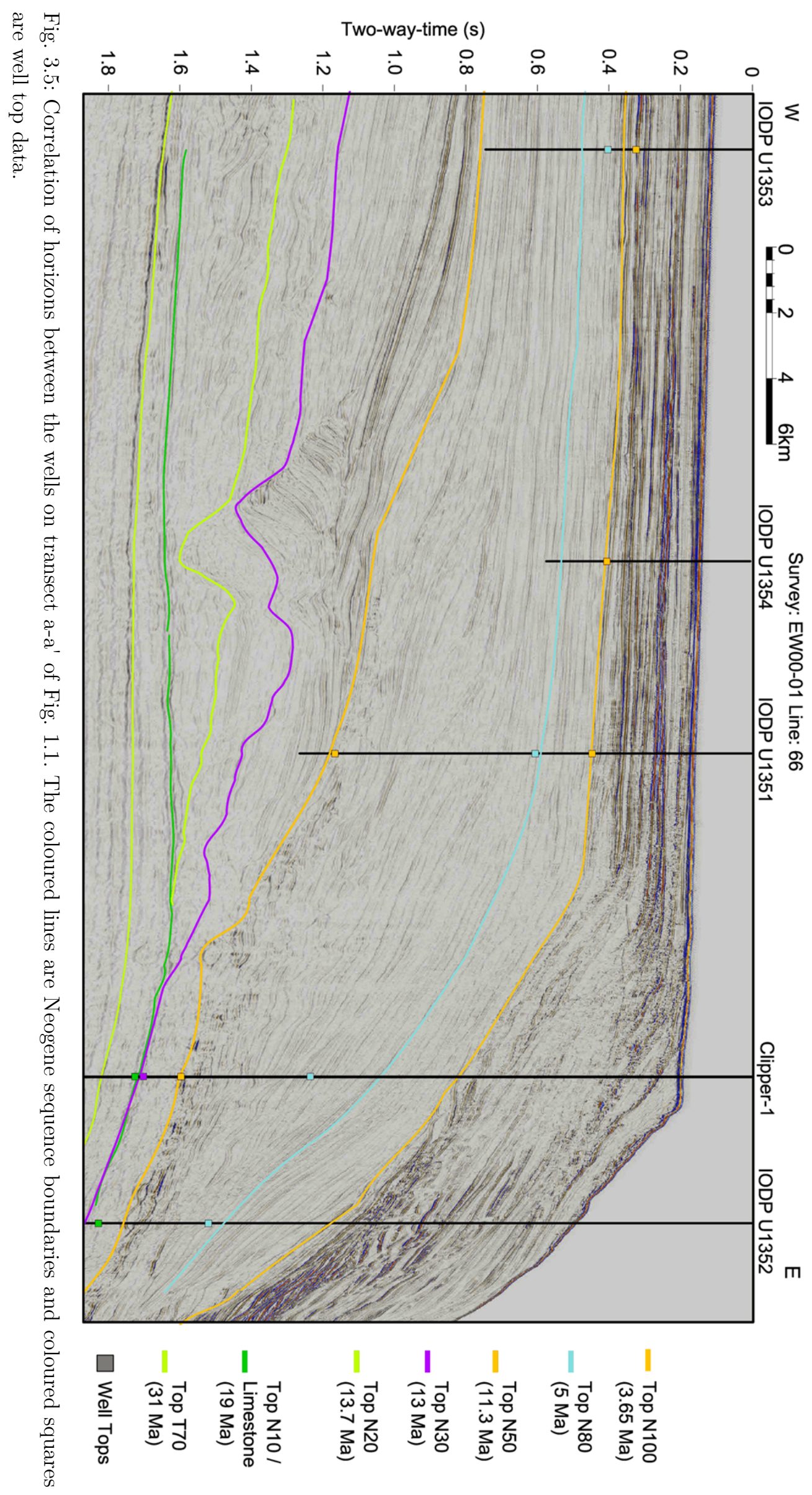




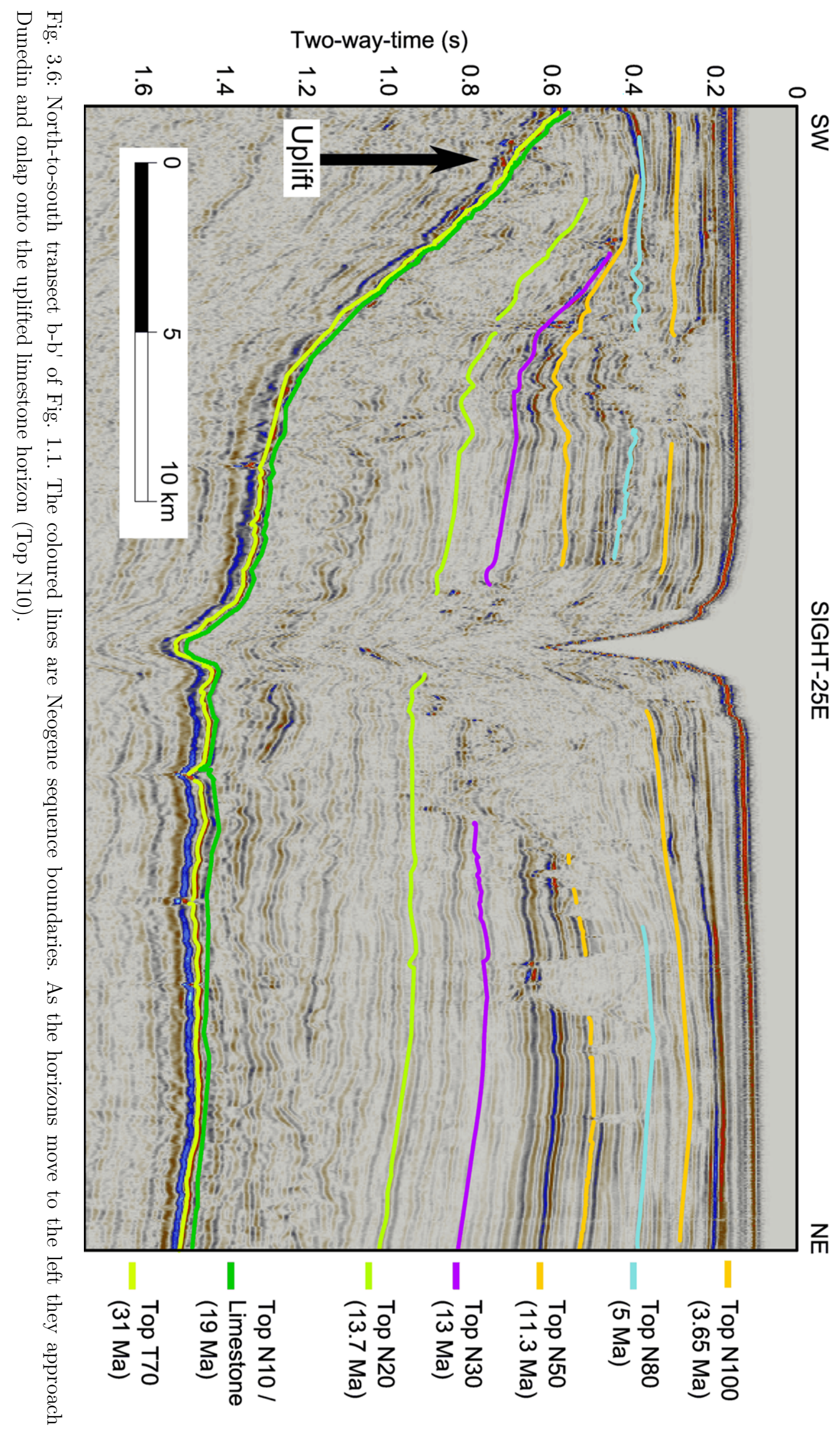




\section{Three-Dimensional deformation of the Otago Shelf}

The purpose of this chapter is to use a flexural model to investigate uplift on the Otago Shelf. Seismic lines in the Canterbury Basin show a prominent reflector, which is the Oligocene limestone horizon (Top T70). The horizon has been uplifted on seismic lines approaching Dunedin (Fig. 3.6), where multiple horizons onlap onto it. This distinct horizon was mapped in the previous chapter and in this chapter it is used as a reference horizon to map uplift. A buoyant load of upwelled asthenosphere beneath the crust may have caused the uplift, which would have implications for petroleum maturity. This explanation is tested using a 3D flexural model, which adds to a previous $2 \mathrm{D}$ flexural model of Godfrey et al. (2001).

\subsection{Introduction}

The Dunedin region has several geophysical anomalies, the cause of which has been the subject of debate. As discussed in section 2.6, wide-angle seismic data has revealed a low-velocity zone in the lower crust and mantle below it and a highly reflective region on a nearby multichannel seismic line, which may represent a hot, fluid-rich, region of the crust. The region also has surface volcanics, a positive gravity anomaly, a high heat flow, and high mantle-helium ratios.

Godfrey et al. (2001) interpret the cause of the anomalies as a buoyant load, probably hot asthenosphere and associated melts, emplaced beneath and into the lower crust during the mid-Miocene. Godfrey et al. (2001) used a 2D flexure model to test if the regional limestone horizon has been uplifted,

possibly by this buoyant load, and found the uplift to be consistent with the model. 
The 2D model had multiple limitations (Mortimer et al. 2002). First, the uplift was viewed on a 2D transect where the changing azimuth and paleoshorelines may have made the limestone appear uplifted. Second, early Miocene uplift was widespread throughout the whole of onshore Otago (Landis et al. 2008), not just restricted to the doming around the Dunedin Volcano. Mortimer et al. (2002) noted that this issue needs close examination using shallow seismic datasets. This chapter undertakes such an examination. In the previous chapter, a seismic dataset was used to construct a 3D map of the limestone horizon and in this chapter it is used as input to a 3D flexure model. This overcomes the problems associated with a $2 \mathrm{D}$ model and is therefore a better test of the question 'Can the uplift of the Oligocene limestone reflector on the Otago Shelf be explained by a buoyant load beneath Dunedin?' If this hypothesis is true, it has implications for the heat flow input and hence the maturity of the petroleum system of the Otago Shelf.

\subsection{Lithospheric Flexure}

Plate tectonics assumes that rigid lithospheric plates float on underlying mantle. On a geological timescale, the lithosphere acts elastically and the underlying mantle acts as a viscous fluid (Fowler 2005). Lithospheric flexure occurs when a force is placed on the lithosphere, perhaps by an ice sheet or magma chamber, causing it to bend elastically and displace viscous mantle (Watts 2001). The flexure can be modelled using a partial differential equation in two dimensions (Van Wees \& Cloetingh 1994):

$$
\nabla^{2}\left(D(x, y) \nabla^{2} \omega\right)+\Delta \rho g \omega=q(x, y)
$$

In this equation, $w$ is the vertical displacement at each cell, centred at $(x, y) . D$ is the flexural rigidity, $\Delta \rho$ is the density contrast between the displaced mantle beneath the elastic plate and the infilling rock in the flexural depression formed above the plate, $g$ is gravitational acceleration, $q$ is the 
applied load, $v$ is Poisson's ratio, and $T_{e}$ is the effective elastic thickness. Flexural rigidity $(D)$ is defined as:

$$
D=\frac{T_{e}^{3}}{12\left(1-v^{2}\right)}
$$

Effective elastic thickness $\left(T_{e}\right)$ is a measure of the lithospheres overall resistance to flexure and depends strongly on lithospheric thermal state and composition (Pérez-Gussinyé et al. 2009). It is effective in the sense that contributions to the elasticity of the lithosphere are likely to come from both upper crust and the upper mantle and therefore $T_{e}$ does not represent a discrete layer, but rather summed contributions from different layers. Where $D$ is an inherent, fixed, property of the lithosphere, it is useful to also define the flexural parameter $(\alpha)$ defined by: $\alpha^{4}=4 D / \Delta \rho g$. The flexural parameter has units of length and is, in effect, the flexural wavelength for a particular loading situation based on the density contrast $\Delta \rho$.

The amplitude and wavelength of the flexure depends on the lithosphere's effective elastic thickness $\left(T_{e}\right)$ and the lateral distribution of imposd buoyancy (q). Typical values of continental $T_{e}$ vary from greater than $80 \mathrm{~km}$ in cratonic regions to around $25 \mathrm{~km}$ in regions of rejuvenated continental lithosphere such as Western Europe (Watts 1992). High heat flow, high finite strain, and high strain rates result in a reduction in $T_{e}$. For example, the highly faulted Wanganui Basin lithosphere has a proposed $T_{e}$ of c. $10 \mathrm{~km}$ (Stern et al. 1992), whereas the adjacent more stable Western Platform has a well constrained $T_{e}$ of $25 \mathrm{~km}$ (Holt \& Stern 1991).

When a plate flexes, the deflected region is filled with air, water, sediment, or basement rock. The infilling material has a smaller density then the mantle that is being replaced so it causes a restoring force $(\Delta \rho g)$. On any given profile, the restoring force can be varied depending on whether deposition or erosion is occurring above the flexed plate. If deposition of sediments is 
occurring then the density contrast is $\Delta \rho=\rho_{m}-\rho_{s}$ where $\rho_{m}$ is the density of the mantle and $\rho_{s}$ is the density of deposited sediment. If the plate is being flexed into air with a climate of high erosion rates then $\Delta \rho=\rho_{m}-\rho_{b}$ i.e. mantle displacing crustal rocks with density $\rho_{b}$. If, however, the plate is being flexed upward and no erosion is taking place then the mantle is replacing air and $\Delta \rho$ $=\rho_{m}-0$. In regions of only moderate erosion some intermediate value of the resorting force needs to be selected (Allen \& Allen 1990).

\subsection{Model}

In this model a hot body is present under Dunedin (Fig. 4.1) where denser mantle has been replaced with hotter and lighter asthenosphere. The body is approximated by an ellipse $75 \mathrm{~km}$ high and c. $140 \mathrm{~km}$ wide with a density contrast of $-35 \mathrm{~kg} / \mathrm{m}^{3}$. The density contrast results in buoyancy, which places an upward load under the elastically flexing lithosphere. We note that the source of buoyancy probably extends up into the lower crust because conducted heat will cause rocks to expand and give rise to buoyancy. However for the purpose of this flexure calculation we need only to propose a net buoyancy, but don't have to specify the distribution of buoyancy with depth. The hot body acts on a weakened lithosphere under Dunedin resulting in a pronounced local uplift. The surrounding lithosphere is stronger and therefore flexes less but over a wider area. The hot body has properties which cause several geophysical anomalies. It is hotter than the surrounding mantle, causing increased surface heat flow and it is less dense than the surrounding mantle, causing buoyant uplift and an isostatic gravity anomaly. 


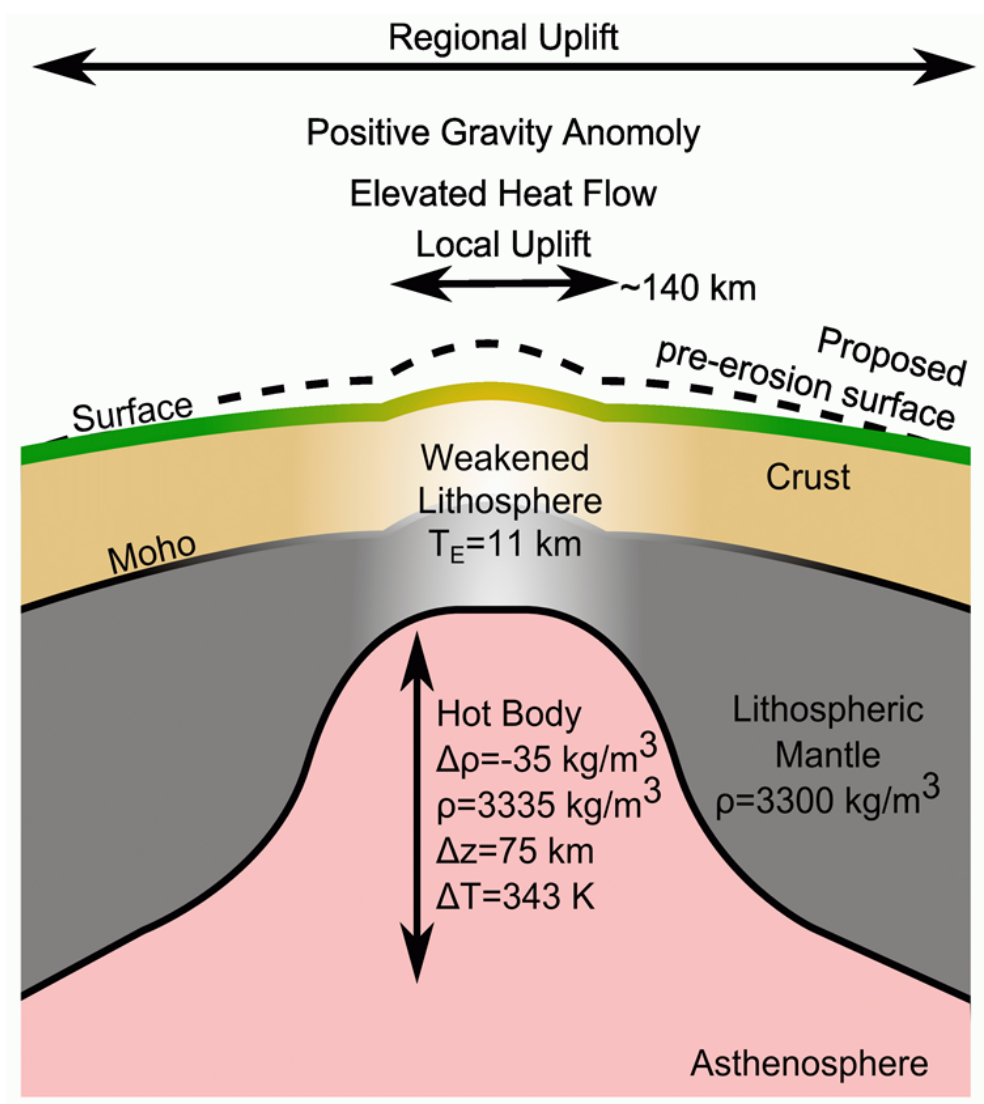

Fig. 4.1: An illustration of flexural uplift as set out in the model. A hot body of asthenosphere replaces denser mantle, causing gravity and heat flow anomalies and placing a buoyant pressure on the lithosphere. In response the lithosphere flexes according to its overall elastic strength $T_{e}$, which is reduced above the load by structural deformation and increased heat flow. The weakened lithosphere has a greater response than the surrounding lithosphere, giving a pronounced local uplift.

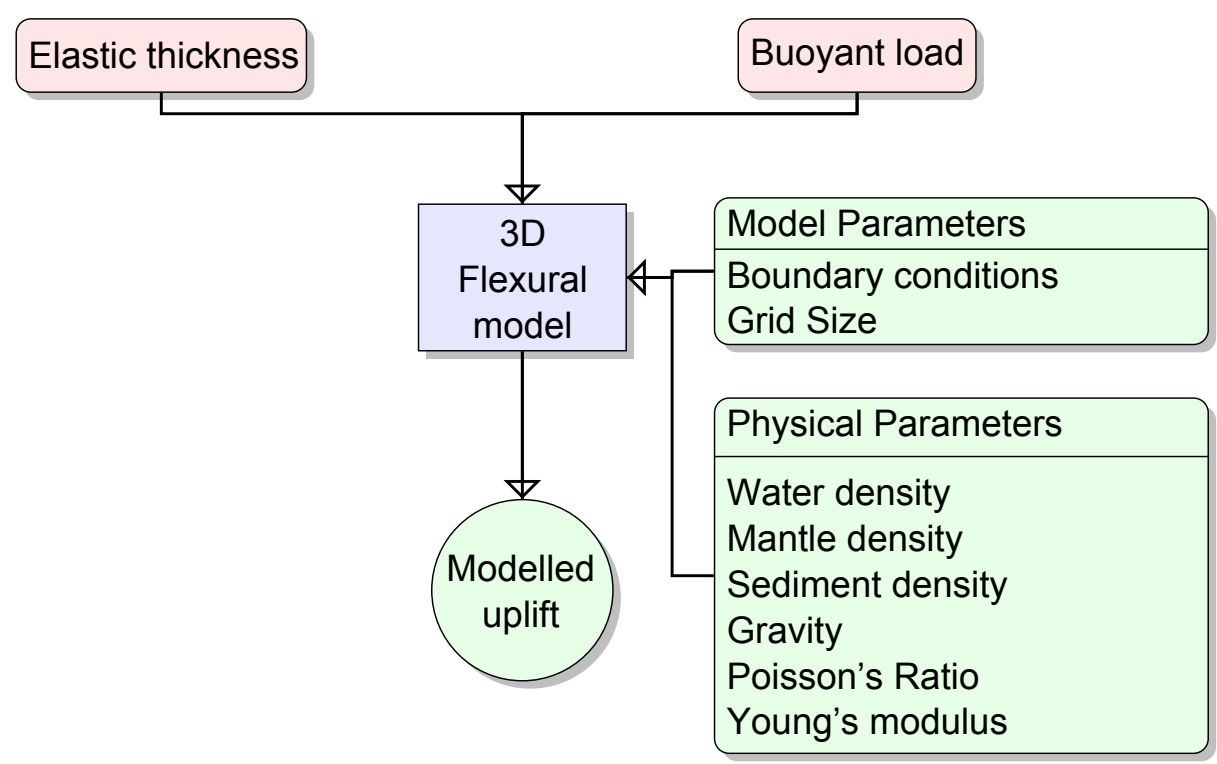

Fig. 4.2: Block diagram of flexure model showing the inputs, parameters, and output. 
A 3D flexural model (Wickert 2014) is used to test if the amplitude and wavelength of the observed uplift could be generated by the buoyant body. Fig. 4.2 shows a block diagram of the model and its inputs, which are load and elastic thickness. The model is configured using several parameters then is run, producing a modelled uplift as output. The output can be compared to the 3D map of the observed uplift or compared with previous models on $2 \mathrm{D}$ transects.

The flexure equation, as set out in the previous section can be solved using a partial differential equation for lithospheric flexure in two dimensions. A numerical solution to this partial differential equation was calculated using a direct finite-difference solution. Calculations were performed using the freely available flexure package (Wickert 2014), which is written in Python (Van Rossum \& Drake 1995) and utilises the UMFPACK (Davis 2004) algorithms for solving unsymmetrical sparse linear systems.

Finite-difference numerical solutions have the advantage of being rapid and allowing variable elastic thickness, but they also have two significant disadvantages. First, the grid spacing must be a significant fraction of the flexural wavelength or solutions will be unrealistic. Second, large changes in the elastic thickness cause unrealistic results. These disadvantages were overcome by testing a range of values for grid spacing and elastic thicknesses and verifying the solutions against a simpler Airy isostatic solution.

\subsubsection{Inputs}

The first input, effective elastic thickness, represents the average elastic thickness of the lithosphere. Godfrey et al. (2001) proposed a $T_{e}$ of $5 \mathrm{~km}$ in their 2D analysis, whereas this thesis found that $11 \mathrm{~km}$ gave a good fit between the 3D model and observations. The increased value remains anomalously low compared to typical values of $20 \mathrm{~km}$ (Watts 1992) and, like 
Godfrey et al. (2001), it is suggested this is due to the localised high heat flow around Dunedin.

The second input is a load (Fig. 4.1), which models a hot body of asthenosphere that has replaced the mantle. The load is specified in terms of a distributed pressure over each cell of the model. The pressure is calculated as $25 \mathrm{MPa}$ using $q_{0}=h \Delta \rho g$ (Watts 2001), where $g$ is the gravitational acceleration, $\Delta \rho$ is the density contrast and $h$ is the height.

The height $h$ is chosen as $75 \mathrm{~km}$, which is the distance between the approximately 25-km-deep Moho and the mantle lid at $100 \mathrm{~km}$ depth. However, we can't rule out that some of the buoyancy is due to thermal expansion in the lower crust due to thermal conduction of heat over the past 10 Ma. This is certainly suggested by the lowered P-wave speeds in the lower crust beneath Dunedin (Fig. 2.8).

The density contrast is chosen as $-35 \mathrm{~kg} / \mathrm{m}^{3}$ which follows Godfrey et al. (2001)'s 2D model. This value explains the difference between Dunedin's surface heat flow and the surrounding region. We can relate the density contrast and the excess heat flow using the thermal expansion equation $\Delta \rho=$ $\rho K \triangle T$ assuming a thermal expansion coefficient of $K=2.9 \times 10^{-5} \mathrm{~K}^{-1}$, a mantle density of $\rho=3300 \mathrm{~kg} / \mathrm{m}^{3}$, and a temperature change at $z=25 \mathrm{~km}$ of $\Delta T=343 \mathrm{~K}$. The temperature change was calculated using the $1 \mathrm{D}$ thermal heat flow equation $\Delta T=z \Delta Q / K$ (Allen \& Allen 1990), where $\Delta Q$ is the excess heat flow above normal values for the South Island (Funnell et al. 1996; Cook et al. 1999).

The load's shape is proposed to be an ellipse that is longer to the northeast and centred c. $25 \mathrm{~km}$ southwest of Dunedin (Table 4.1). The spatial extent is chosen to approximate regional anomalies (Fig. 4.3) such as the uplifted limestone reflector, a broad region of positive gravity anomaly, distributed Cenozoic basalt-volcanism, and the elevated heat flow. In 
particular, we correlate (Fig. 4.3) the high heat flow and excess buoyancy of the Dunedin area with a distinctive isostatic gravity anomaly of c. 35 mGal that has a regional extent of c. $80 \mathrm{~km}$ by $60 \mathrm{~km}$ (Reilly 1972). The gravity anomaly is distinct from localises zones of anomalous high gravity to the south which are linked to the Permian thrust and ultramafic zone and to the north where there may be a link to the Waihemo Fault (Field \& Browne 1989; Mortimer et al. 2002). If the elevation above sea level of an area is supported by crustal thickening and Airy-style local compensation, then no isostatic anomaly should be observed. If, however, excess elevation is due to thermal or dynamic processes in the deep lithosphere then a positive isostatic anomaly can be created (Lyon-Caen \& Molnar 1989). A rough estimate for the magnitude of such a positive isostatic anomaly is made by considering a simple Bouguer plate analysis $\Delta g=2 \Pi G \Delta \rho \Delta h$ (Allen \& Allen 1990), where $G$ is the universal gravitational constant of $6.673 \times 10^{-11} \mathrm{~m}^{3} \mathrm{~kg}^{-2} \mathrm{~s}^{-1}$ and $\Delta h$ is the excess elevation. If the density contrast is $\Delta \rho=2700 \mathrm{~kg} / \mathrm{m}^{3}$ and the anomalous gravitational acceleration is $\Delta g=35 \mathrm{mGal}$ then the excess elevation $\Delta h$ is c. $300 \mathrm{~m}$. This seems a plausible result as this part of eastern Otago seems overelevated at c. 0-400 m elevation (Charting Around New Zealand Group 2008) for its decreased crustal thickness of 22-32 km (Godfrey et al. 2001; Mortimer et al. 2002) compared to average South Island coastal values of $30 \mathrm{~km}$ (Christensen \& Mooney 1995; Godfrey et al. 2001; Melhuish et al. 2005).

\begin{tabular}{ll}
\hline Rotation & $40^{\circ}$ \\
Long Radius & $87.5 \mathrm{~km}$ \\
Short Radius & $62.5 \mathrm{~km}$ \\
Northing centre & $4,919,421 \mathrm{~m}$ \\
Easting centre & $1,383,836 \mathrm{~m}$ \\
Coordinate Projection & New Zealand Transverse Mercator \\
Density contrast & $-35 \mathrm{~kg} / \mathrm{m}^{3}$ \\
Load thickness & $75 \mathrm{~km}$ \\
Top of load & $25 \mathrm{~km}$ \\
\hline
\end{tabular}

Table 4.1: Parameters used in generating the buoyant load. 


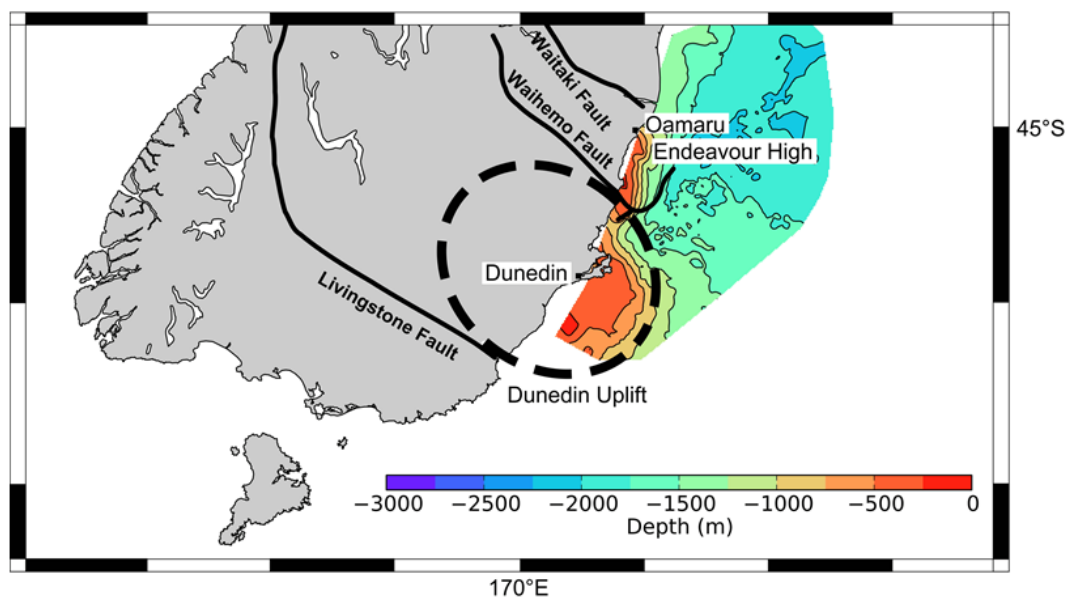

(a)
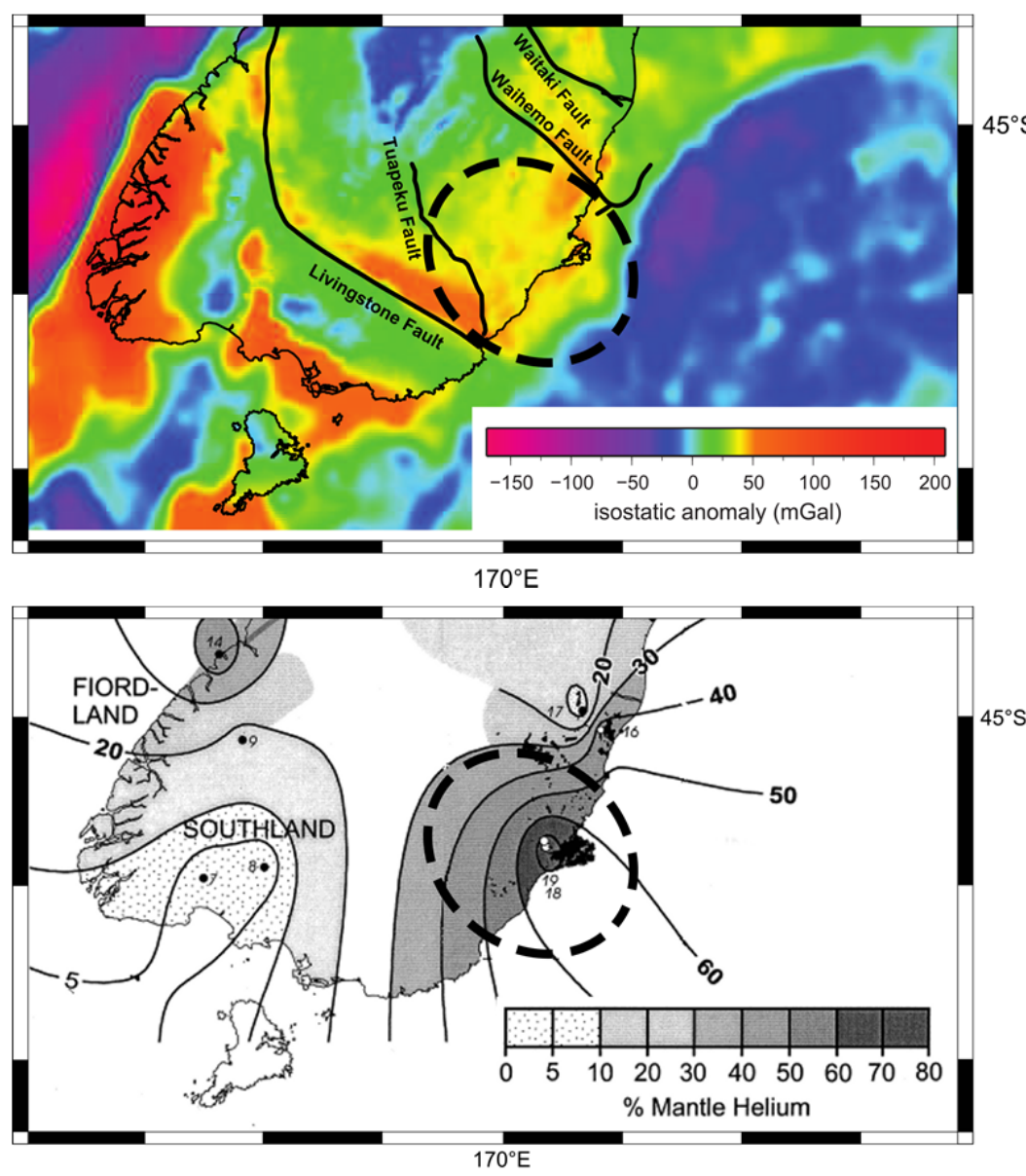

(b)

(c)

Fig. 4.3: A comparison of the anomalies around Dunedin. A, Depth map of the regional limestone reflector with the uplift and major Neogene fault labelled and the extent of the proposed load marked as a dashed ellipse. B, The isostatic gravity anomaly in mGal with major Neogene faults marked (modified from Field \& Browne (1989); Mortimer et al. (2002); Bourguignon 2009). C, The contours for mantlehelium, with the areal spread of Late Cenozoic basalts in black (modified from Hoke et al. 2000). 


\subsubsection{Parameters}

Several parameters (Table 4.2) need to be set within reasonable bounds or the model will fail and give unrealistic results such as erratic high-frequency waves or undefined values. The most important parameters are the grid size and boundary constraint. The grid size needs to be a fraction of the flexural wavelength. To determine an acceptable range of grid sizes the model was run repeatedly and the solutions were compared to a simple isostatic model. The grid size used was $16200 \mathrm{~m}$ in both the north and east direction (in the New Zealand Transverse Mercator projection). The boundary conditions were set to 'no outside load', where the model assumes that there are no loads outside the model. The infill density was chosen as the density of water to represents mantle displacing water offshore or a moderate amount of erosion in onshore areas (Allen \& Allen 1990).

\subsection{Uplift Data}

The uplifted surface is the Top T70 limestone reflector from the previous chapter (Fig. 4.4). The data sources and methods used to generate this surface are covered in Sections 3.2 and 3.3, but data must be adjusted before it can be compared to the modelled flexure. The model assumes that the limestone was deposited horizontally at mean sea-level and that all subsequent deformation is due to uplift. However, the surface was deposited at a certain water depth, and subsequent to this, extensive sediment loading during the Neogene caused post-depositional deformation. Two corrections can be made that help alleviate the effect of these assumptions. 


\begin{tabular}{ll}
\hline Gravity $(g)$ & $9.8 \mathrm{~m} / \mathrm{s}^{2}$ \\
Poisson's Ratio $(\nu)$ & 0.25 \\
Young's modulus $(E)$ & $1.0 \times 10^{11} \mathrm{~Pa}$ \\
Deposition depth & $1100 \mathrm{~m}$ \\
Water density $\left(\rho_{w}\right)$ & $1000 \mathrm{~kg} / \mathrm{m}^{3}$ \\
Mantle density $\left(\rho_{m}\right)$ & $3300 \mathrm{~kg} / \mathrm{m}^{3}$ \\
Sediment density $\left(\rho_{s}\right)$ & 220 \\
Infill Density $\left(\rho_{w}\right)$ & $1000 \mathrm{~kg} / \mathrm{m}^{3}$ \\
Grid Size & $16200 \mathrm{~m}$ \\
Boundary conditions & No effect from \\
& outside loads \\
\hline
\end{tabular}

Table 4.2: Parameters used in flexural modelling.

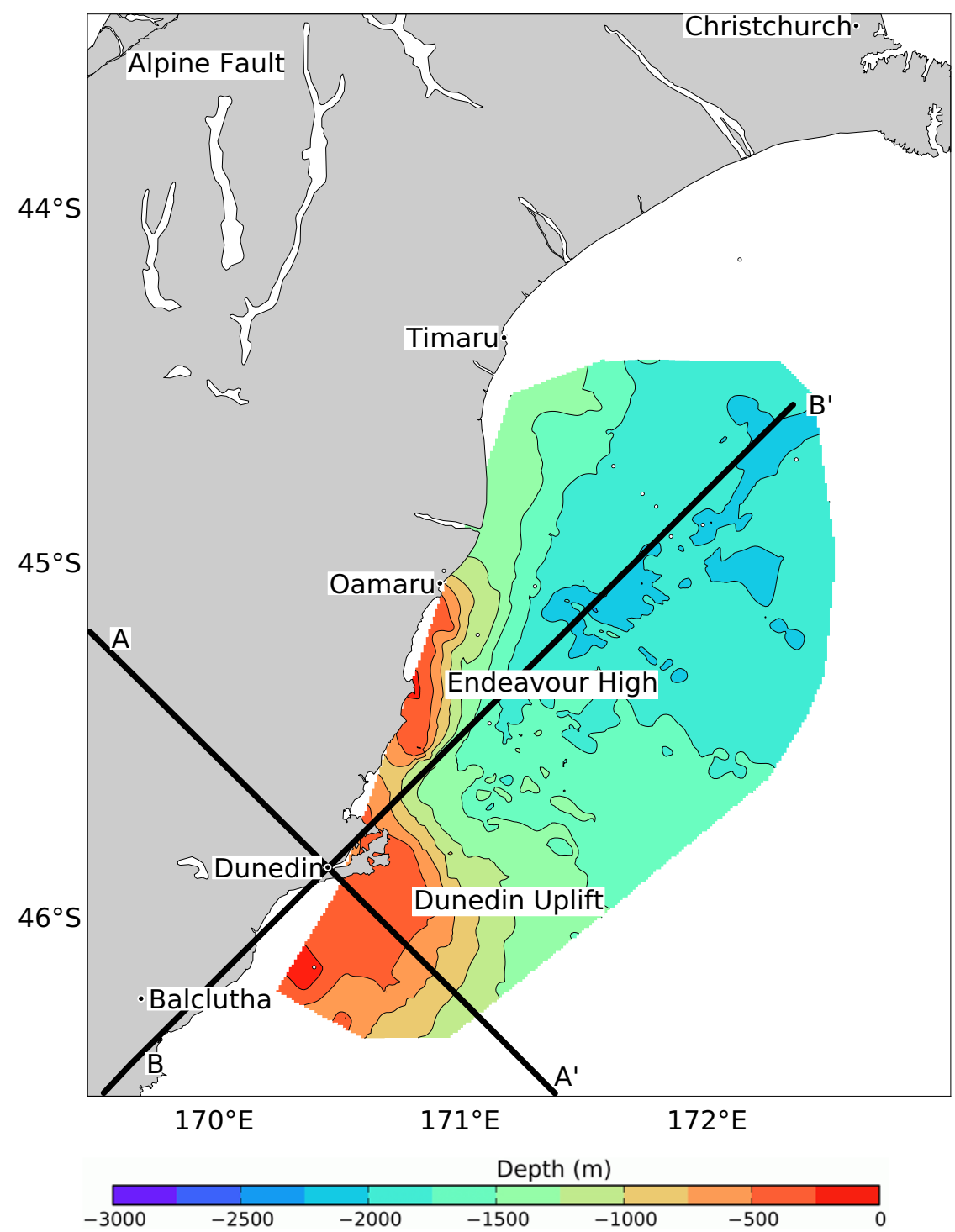

Fig. 4.4: Depth map of the uplifted limestone horizon with transects A and B. 


\subsubsection{Adjusting for depositional depth}

Adjusting for paleobathymetry is difficult. Ideally a map of paleobathymetry could be used to remove the effect of varying depositional depth. In the absence of such a map, this thesis assumes a depositional depth of $1100 \mathrm{~m}$, which falls within published values of 250-2000 m (Field \& Browne 1989; Lu 2004; Funnell 2005). The most relevant value is taken from Oligocene samples of the uplifted horizon (Expedition 317 Scientists 2011) which included lower bathyal foraminifera that indicate a water depth of 1000-2000 m. The assumption of a constant bathymetry is valid for a small area, especially areas of constant crustal thickness, but becomes unreasonable over larger areas. The validity of this assumption is discussed further in section 4.6.

\subsubsection{Adjusting for post-depositional deformation}

The Neogene sediment loading was removed using back-stripping methods (Allen \& Allen 1990). In some locations, more than $1 \mathrm{~km}$ of post-limestone sediment was deposited which acted as a load and caused downward subsidence. The amount of subsidence was calculated assuming Airy isostasy and removed. The result is a surface where the remaining deformation is assumed to be the result of the mid-Miocene uplift.

In Airy isostasy each cell is assumed to be a column at vertical isostatic equilibrium with no elastic effects. The vertical displacement $(w)$ was calculated using the equation $w=q_{0} /\left(\rho_{m}-\rho_{w}\right)$ (Watts 2001), where $\rho_{m}=3300$ $\mathrm{kg} / \mathrm{m}^{3}$ is the average density of mantle and $\rho_{w}=1000 \mathrm{~kg} / \mathrm{m}^{3}$ is the density of the water infill. The load $\left(q_{0}\right)$ was calculated using $q_{0}=h \Delta \rho g$ (Watts 2001), where $g$ is the gravitational acceleration, and $\Delta \rho$ is the density difference between water $\left(\rho_{w}=1000 \mathrm{~kg} / \mathrm{m}^{3}\right)$ and the Neogene sediment $\left(\rho_{s}=2200\right.$ $\mathrm{kg} / \mathrm{m}^{3}$ ) (Hatherton \& Leopard 1964). The sediment thickness $h$ was calculated 
using the depth difference between the uplifted limestone horizon and modern seafloor.

It may seem contradictory to use Airy isostasy for the back-stripping correction but lithospheric flexure to determine the uplift process. This apparent contradiction can be explained by the observation that the sedimentary units are spread over lateral distances comparable or greater than any reasonable value of flexural wavelength. In this situation the sediments are effectively compensated by Airy isostasy, rather than being supported by the flexural strength of the lithosphere.

The use of back-stripping in this model contrasts with Godfrey et al. (2001). Where this model uses one load and a single value for $T_{e}$, the previous model uses two loads and spatially varies $T_{e}$ to account for post-depositional deformation. The approach used in this thesis has the advantage of using a constant $T_{e}$ which simplifies the model and avoid the errors that occur with a rapidly varying $T_{e}$.

\subsection{Results}

The best fitting model used a load of $26 \mathrm{MPa}$ on a weakened plate with an elastic thickness of $11 \mathrm{~km}$. The input load is an ellipse centred $25 \mathrm{~km}$ southwest of Dunedin (Fig. 4.5a). The modelled uplift is shown in 3D (Fig. 4.5b) and in an alongshore transect (Fig. 4.6a). A second offshore transect is shown in Fig. 4.6b but the fit is poor until a linear ramp function is applied to account for paleobathymetry. This adjustment assumes that in the offshore direction the crust thins, leading to increased post-rift thermal subsidence and therefore increasing paleowater depth.

The sensitivity of the model was tested by varying one parameter while holding other parameters constant. Varying the load by $5 \mathrm{~kg} / \mathrm{m}^{3}$ was enough to give a poor fit to the observed uplift (Fig. 4.7a). Similarly, varying the elastic 
thickness by $2 \mathrm{~km}$ also gave a poor fit (Fig. 4.7b). If the models parameters were varied together they would give a wider range of results, reflecting the fact that this model is not a unique solution to the observed data.

\subsection{Discussion}

The model has a good fit on the northeast trending transect. This implies that a weak plate acted on by a buoyant load can explain the uplift around Dunedin. The buoyant load is equivalent to a $75 \mathrm{~km}$ column of mantle being replaced with asthenosphere and giving a density contrast of $-35 \mathrm{~kg} / \mathrm{m}^{3}$, which is consistent with the high heat flows observed in the area. Some of the buoyancy can be attributed to thermal expansion of the crust, in which case the column of mantle would be smaller. The weakened plate implies that the lithosphere in the area has been thermally or structurally weakened compared to typical values of $20 \mathrm{~km}$ (Watts 1992) and, like Godfrey et al. (2001), it is suggested here that this is due to the localised high heat flow around Dunedin.

There are three notable differences between this thesis's model and the previous SIGHT model (Table 4.3)(Godfrey et al. 2001). First, the SIGHT model is a $2 \mathrm{D}$ model and therefore assumes no variation perpendicular to the cross-section. It models a rectangular load that spans c. $100 \mathrm{~km}$ along the coast and is infinite in the perpendicular direction. In contrast, the 3D nature of the model presented here is larger along the coast and is limited in the perpendicular direction. A 3D model brings the additional difficulty of positioning the load, but even an inexact choice of position is an improvement over a 2D arrangement. 


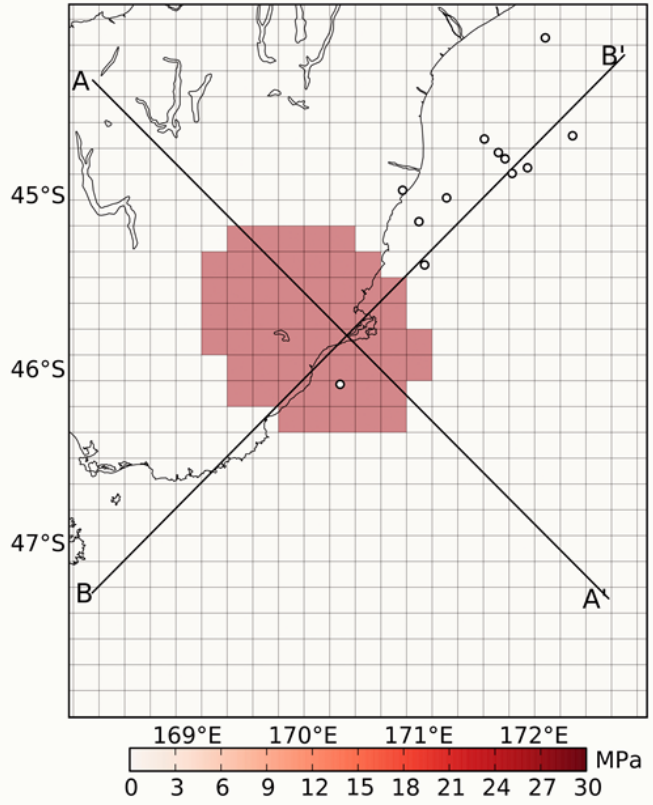

A

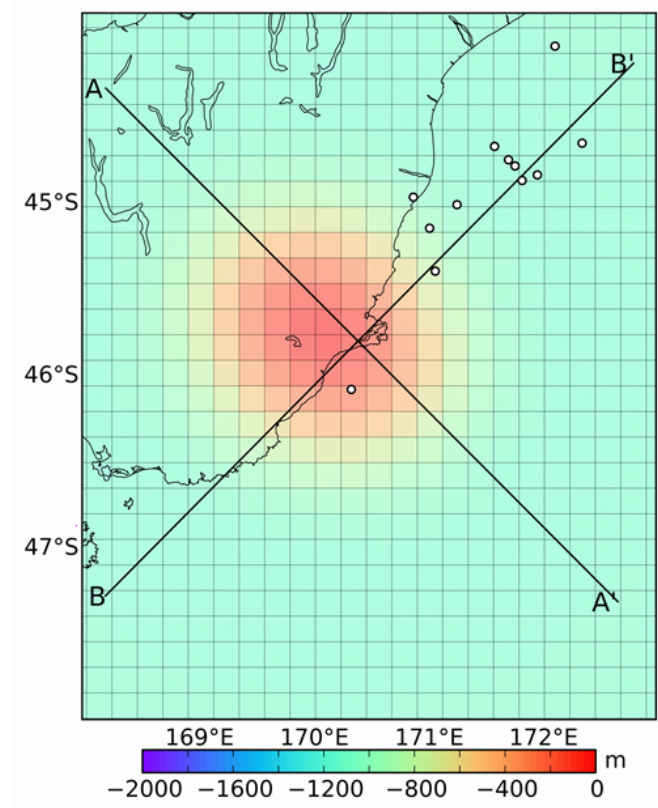

B

Fig. 4.5: A, The input load B, Modelled upward deflection. Model cells are shown as filled squares, labelled lines show transects, and the circles show places or wells from Fig. 1.1. The deflection is measured in metres below sea sea-level relative to an estimated deposition depth of $1100 \mathrm{~m}$.

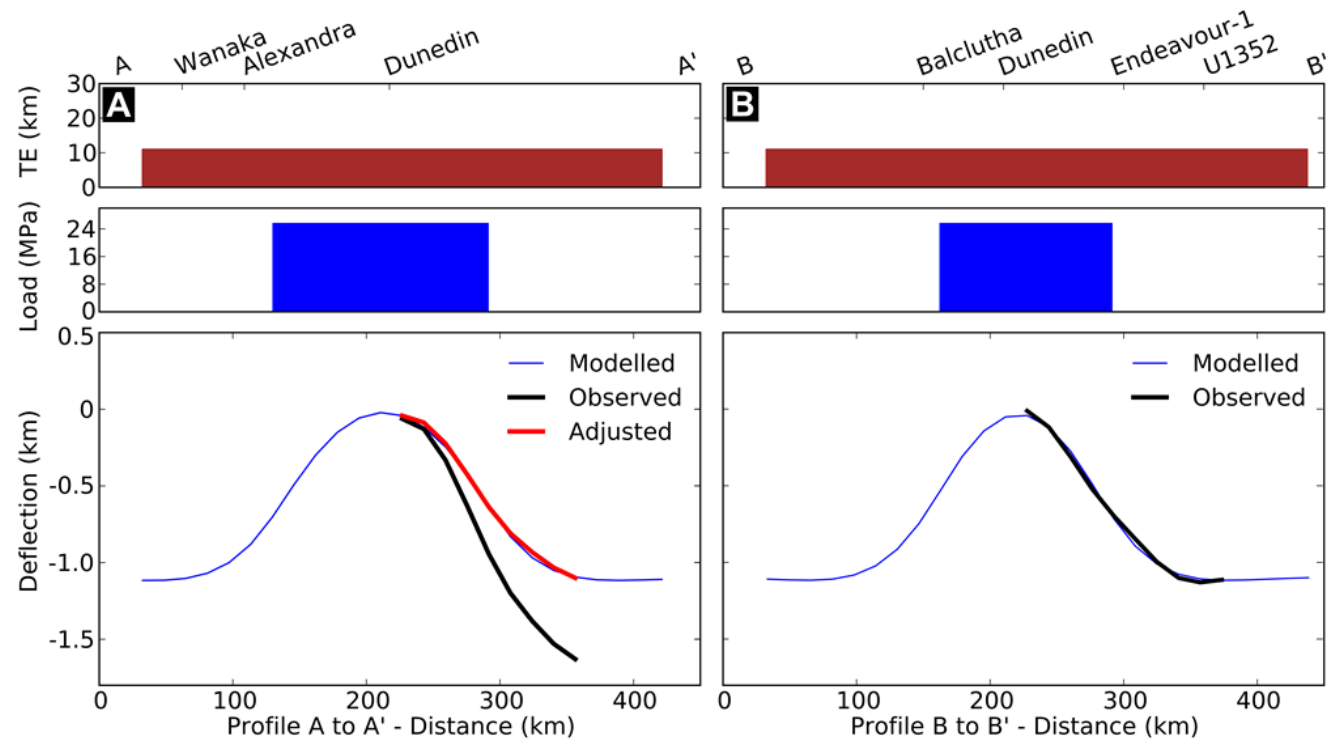

Fig. 4.6: A, Modelled and observed uplift on a southeast transect A-A' of Fig. 4.4 with a poor fit. The fit is improved if varying paleobathymetry is accounted for using a linear adjustment. B, Modelled and observed uplift on a northeast transect B-B' of Fig. 4.4 which is comparable to the SIGHT transect used in Godfrey et al. (2001). The top panel shows the elastic thickness in kilometres, the middle panel shows the buoyant load in MPa, and the third shows the real (black), real adjusted (red), and modelled (blue) deflection from an estimated deposition depth of $1100 \mathrm{~m}$. 

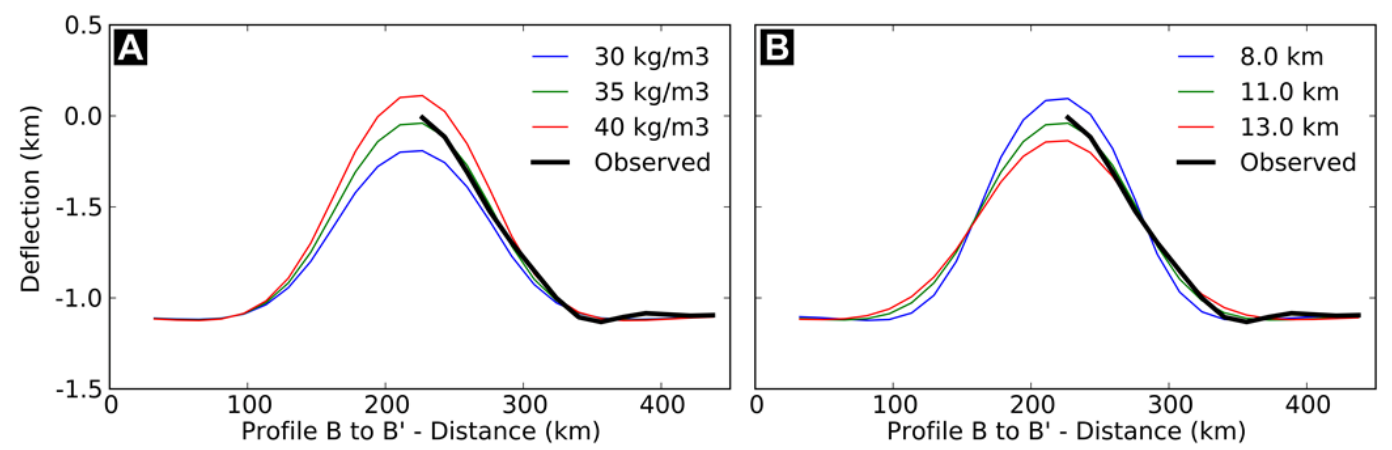

Fig. 4.7: Testing the models sensitivity A, to load and B, to elastic thickness on transect B-B'. The real and modelled deflections are shown at an estimated deposition depth of $1100 \mathrm{~m}$.

\begin{tabular}{lll}
\hline Model & SIGHT model & This thesis \\
Model dimension & $2 \mathrm{D}$ & $3 \mathrm{D}$ \\
Elastic thickness near load & $5 \mathrm{~km}$ & $11 \mathrm{~km}$ \\
Load northeast length & $\sim 60 \mathrm{~km}$ & $87.5 \mathrm{~km}$ \\
Load northwest length & infinite & $62.5 \mathrm{~km}$ \\
Load thickness & $75 \mathrm{~km}$ & $75 \mathrm{~km}$ \\
Load centre & Dunedin & $25 \mathrm{~km} \mathrm{SW}$ of Dunedin \\
Density contrast & $-35 \mathrm{~kg} / \mathrm{m}^{3}$ & $-35 \mathrm{~kg} / \mathrm{m}^{3}$ \\
Deposition depth & $\sim 250 \mathrm{~m}$ & $1100 \mathrm{~m}$ \\
Sensitivity to load & $<5 \mathrm{~kg} / \mathrm{m}^{3}$ & $<5 \mathrm{~kg} / \mathrm{m}^{3}$ \\
Sensitivity to elastic thickness & Unstated & $<2 \mathrm{~km}$ \\
\hline
\end{tabular}

Table 4.3: Comparison of this flexural model to the previous SIGHT model (Godfrey et al. 2001).

Second, the load in this thesis is $25 \mathrm{~km}$ southwest from the centre of the SIGHT model. This can be explained by the 3D nature of this model and the fact that neither model has enough data to limit the extension of the load to the southwest or northwest.

Third, it is assumed here that the limestone horizon was deposited in water of $1100 \mathrm{~m}$ depth, compared to $250 \mathrm{~m}$ in the previous model. These differing depths reflect different assumptions about the paleobathymetry. This thesis uses a 3D isopach map and an Airy isostatic model to remove Neogene subsidence. The remaining depth of $1100 \mathrm{~m}$ in the central basin is assumed to 
be the depth at which the limestone was deposited, which falls within published values of 250-2000 m (Field \& Browne 1989; Lu 2004; Funnell 2005; Expedition 317 Scientists 2011). The most recent value for the water depth comes from lower bathyal foraminifera in samples near the uplifted horizon, indicating a water depth of 1000-2000 m, and signalling that a larger value is a reasonable assumption.

Mortimer et al. (2002) noted two possible problems with the SIGHT flexure model which can now be revisited. The first problem is that the limestone horizon may not have been deposited horizontally but rather at a varying paleobathymetry. During post-rift thermal relaxation, areas of greater crustal thickness experience a greater thermal relaxation, resulting in varying paleobathymetry. The angle between a SIGHT line azimuth and varying paleobathymetry has perhaps contributed to only an apparent uplift of the limestone reflector.

The analysis presented here partially accounts for this problem. The doming has now been mapped and modelled in 3D, and it is still evident. Furthermore, the reprocessed 2D SIGHT line in Fig. 3.6 shows onlap onto the uplift with greater clarity. This confirms the doming effect, but varying paleobathymetry still has a large effect on the model. The poor fit on the offshore transect (Fig. 4.6a) becomes a good fit when varying paleobathymetry is accounted for using a linear ramp function. This implies that the paleobathymetry needs to be taken into account if the model is to fit in the offshore direction and over larger areas.

The second problem is that Neogene uplift was widespread throughout the whole of onshore Otago, not just restricted to the doming around the Dunedin Volcano (Mortimer et al. 2002). Therefore doming around Dunedin may be an offshore portion of a wider central Otago uplift. However, the broad Otago uplift in the Neogene is not well constrained and there is geological evidence 
that it did not extend to Dunedin prior to volcanism there (Coombs et al. 1960; LeMasurier \& Landis 1996). There is still conjecture on the broad Otago uplift and there could be a variety of causes (LeMasurier \& Landis 1996; Landis et al. 2008). There are no prominent faults in the vicinity of Dunedin (Mortimer et al. 2002) so it is difficult to attribute uplift here to crustal thickening linked to plate convergence. Indeed, as discussed in Section 4.3.1, the positive isostatic gravity anomalies (Fig. 4.3) point towards an alternative cause. The pattern of uplift is more supportive of thermal uplift linked to midMiocene volcanism, as suggested by Godfrey et al. (2001). The elevated heat flow and volcanics over a similar area corroborate this, but it cannot be ruled out that some of the Dunedin uplift is merely far-field effects of the central Otago uplift.

\subsubsection{Relevance to the Petroleum System}

This section shows that the uplift around Dunedin can be explained by emplaced asthenosphere under Dunedin. In this scenario, a $75 \mathrm{~km}$ column of mantle was replaced with asthenosphere and caused uplift, possibly between 19 and 13.7 Ma. This was followed by volcanism at the Dunedin volcanic centre between 16.0 and 10.1 Ma (Hoernle et al. 2006; Coombs et al. 2008). The enhanced basal heat flow has conducted to the surface and caused an elevated thermal gradient in the region. In this scenario, the petroleum system has much greater potential than in previous isothermal models (Funnell 2005; Mogg 2008).

Most petroleum models for the Canterbury Basin use a standard steady state-geotherm. Anomalies are assumed to be restricted to sample locations because they are caused by the extra heat of igneous intrusions (Funnell 2005;

Mogg 2008). In contrast, Funnell et al. (1996) considers that anomalies may be regional effects connected to the high heat flow around Dunedin. In this 
scenario heat increases at $25 \mathrm{~km}$ depth at $13 \mathrm{Ma}$, which causes source rock to be more mature at a given depth than in other models. The depth of peak oil generation rises to c. $3 \mathrm{~km}$ burial depth, suggesting that the region immediately offshore Dunedin is a potential source kitchen.

What if the increased heat started at a different age and depth? We can compare different emplacement depths and times to determine if thermal maturity is enhanced or reduced. Heat flow can be modelled using a simple linear model of an instantaneous temperature increase (Fig. 4.8). Heat flow is expressed as a function of time $(t)$ and distance $(r)$ (Fowler 2005):

$$
\mathrm{q}(\mathrm{r}, \mathrm{t})=\lambda \Delta \mathrm{T} / \sqrt{\pi \mathrm{tk}} \mathrm{e}^{-\mathrm{r}^{2} / 4 \mathrm{kt}}
$$

In this equation the increased temperature around the emplacement is $\Delta T$ $=343 \mathrm{~K}$, based on temperatures predicted in the upper mantle from the high heat flow around Dunedin (see Section 4.3.1)(Funnell et al. 1996; Cook et al. 1999). Here $k=\lambda / \rho_{c}$ is the thermal diffusivity, where $\lambda=3 \mathrm{~W} / \mathrm{m} / \mathrm{K}$ is the thermal conductivity of granite (Cho et al. 2009), and $\rho_{c}$ is the volume heat capacity of $4.0 \mathrm{E} 6 \mathrm{~J} / \mathrm{m}^{3} / \mathrm{K}$.

The result of this model is shown in (Fig. 4.8) for different depths and ages. We can constrain the age to $16 \mathrm{Ma}$ which is the earliest date of Dunedin volcanism (Hoernle et al. 2006). Compared to the South Island average, the area around Dunedin shows an elevated heat flow of $25 \pm 9 \mathrm{~mW} / \mathrm{m}^{2}$ (Funnell et al. 1996). This is consistent with an emplacement depth between $13.4 \mathrm{~km}$ and $25 \mathrm{~km}$ which results in increased heat flow of $23-33 \mathrm{~mW} / \mathrm{m}^{2}$. This prediction is in keeping with the seismic section, which shows heavy perturbation of the crust from $13.4 \mathrm{~km}$ to the Moho at around $25 \mathrm{~km}$ (Fig. 2.8). The perturbations are low $\mathrm{P}$-wave speeds within the crust which are interpreted to be due to intrusion of magma and heat conduction within the lower crust. 


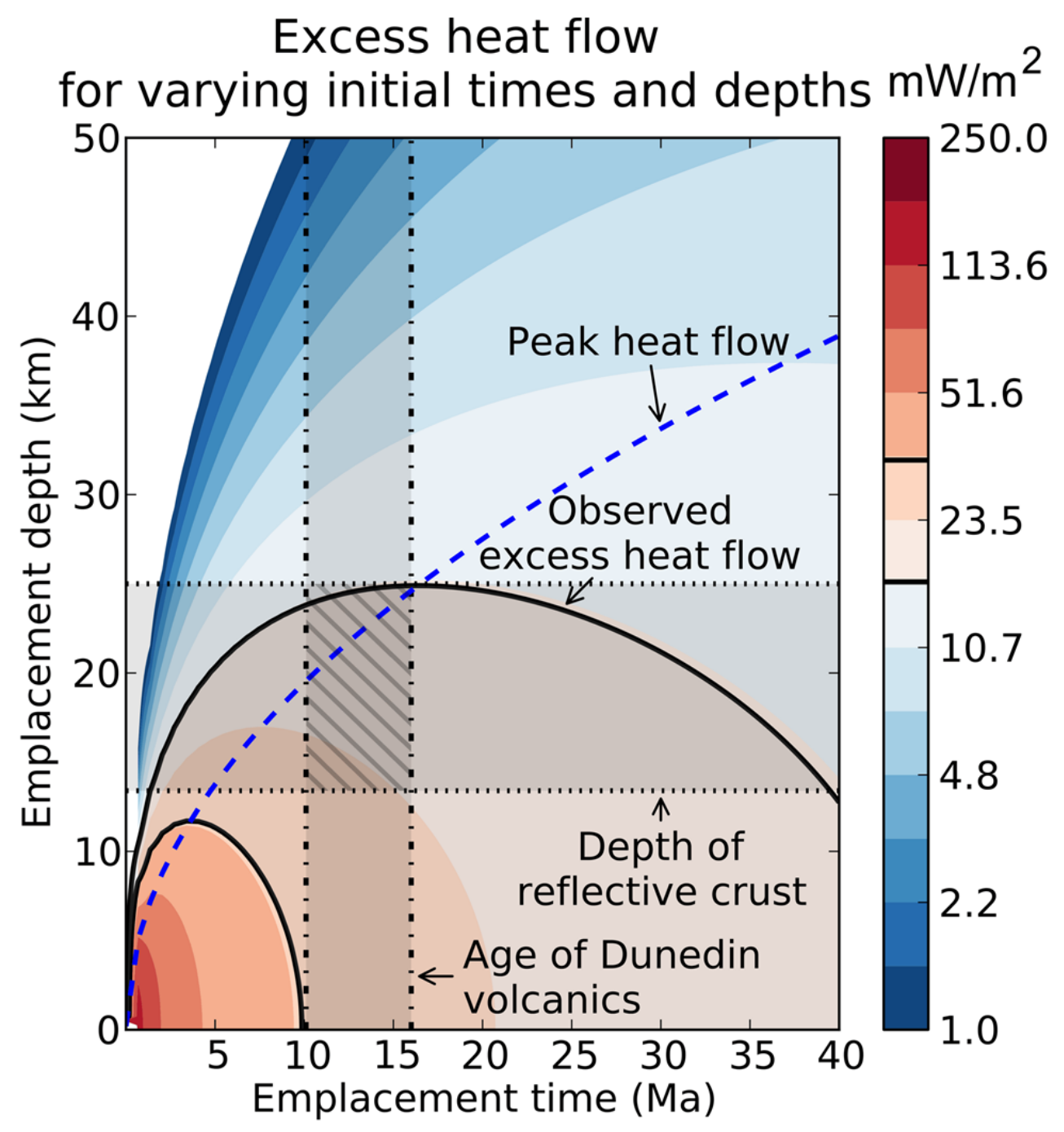

Fig. 4.8: Excess heat flow is produced at the surface by hot emplacements at varying times and depths. The black lines show constraints on emplacement depths and times which overlap in a rectangle of likely times and depths. The solid black lines show the range of observed excess heat flows $\left(16-35 \mathrm{~mW} / \mathrm{m}^{2}\right)$, the dotted lines show the depth of seismic anomalies $(13.4-25 \mathrm{~km})$, and the dash-dot lines show the age of the Dunedin Volcanics (11-16 Ma). Peak heat flow is shown by the blue dashed line. The region appropriate for Dunedin volcano is shown by the lined region.

\begin{tabular}{llll}
\hline $\begin{array}{l}\text { Depth } \\
(\mathbf{k m})\end{array}$ & $\begin{array}{l}\text { Age } \\
(\mathbf{M a})\end{array}$ & $\begin{array}{c}\text { Maturity compared to: } \\
\text { Increased heat model }\end{array}$ & Isothermal model \\
\hline 25 & 16 & Similar maturity & Significantly more mature \\
19 & 16 & More mature & Significantly more mature \\
13.4 & 16 & More mature & Significantly more mature \\
\hline
\end{tabular}

Table 4.4: How a hot emplacement would affect petroleum maturity for several scenarios. The maturity in each scenarios is compared to an 'increased heat' model (Funnell et al. 1996) and a standard heat flow model (Mogg 2008). 
Table 4.4 explores how petroleum maturity would be affected by emplacement at three notable depths: $13.4 \mathrm{~km}$ which is the depth to the top of a section of reflective mid-crust, $19 \mathrm{~km}$ which is the top of a slow and highly reflective lower crust, and $25 \mathrm{~km}$ which is roughly the Moho depth (Godfrey et al. 2001). The scenarios are compared to an 'increased heat flow' petroleum model (Funnell et al. 1996) and a 'standard heat flow' petroleum model (Mogg 2008). We can conclude that an emplacement of hot asthenosphere would result in enhanced petroleum maturity near Dunedin similar to that modelled in Funnell et al. (1996). However if the top of the emplacement is above $25 \mathrm{~km}$ then source rock maturity may be more enhanced than in the Funnell et al. (1996) model.

\subsubsection{Further work}

This model is based on the offshore data that are available to the public at the time of writing (2014). The data are limited by the lack of onshore data and wells. An additional well has been drilled in the early part of 2014, and at a future date the results from this well will be made public. This together with future seismic acquisition will allow the uplift model here to be better refined. Onshore data could also be used to better constrain the uplift in the northwest. Evidence for rock uplift in the onshore regions could be gained from mudstone porosity data or fission track methods. Further investigation of the positive gravity anomaly in the area could enhance the model by adding another constraint. The proposed load could be used in a gravity model and compared to the observed gravity anomaly.

\subsection{Summary}

This chapter uses a 3D flexural model to investigate uplift on the Otago Shelf, where an Oligocene limestone horizon has been uplifted. The model tests 
whether a buoyant load emplaced beneath the crust can explain the observed uplift. The test was previously performed with a 2D model (Godfrey et al. 2001) and this chapter extends this using a 3D model and greater input data.

The best fitting model uses an elliptical $26 \mathrm{MPa}$ load under a weakened plate. The load has an average radius of $71 \mathrm{~km}$, centred $25 \mathrm{~km}$ southwest of Dunedin (Fig. 4.5). It is equivalent to a $75 \mathrm{~km}$-thick column of mantle being replaced by asthenosphere, giving a density contrast of $-35 \mathrm{~kg} / \mathrm{m}^{3}$. However the proposed $75-\mathrm{km}$-high mantle column is likely to be smaller because some of the load could arise from thermal expansion in the crust. The load acts on a plate with an elastic thickness of $11 \mathrm{~km}$, which indicates thermally weakened crust.

The modelled uplift has a good fit on an alongshore transect (Fig. 4.6b) similar to that used by a previous model (Godfrey et al. 2001). A second offshore transect has a poor fit until a linear ramp function is applied to account for paleobathymetry. This adjustment assumes that the crustal thickness decreases offshore which results in greater subsidence during post-rift thermal subsidence.

The analyses suggest that this part of eastern Otago was uplifted by thermal processes strongly linked in both time and space to Miocene volcanism. The process described herein gives the eastern south Island its distinct bulge that appears to be centred at Dunedin. In contrast, central Otago appears to be have been uplifted by processes linked to plate boundary collision, although there is still conjecture on exactly how (Landis et al. 2008), and the relationship with the Dunedin uplift in the Neogene is unclear.

The proposed hot and buoyant load emplaced at $16 \mathrm{Ma}$ and between 13 and $25 \mathrm{~km}$ depth explains the elevated heat flow near Dunedin. This scenario includes enhanced source rock maturity caused by the added heat. This may indicate existing kitchens are more mature than previously thought and highlight potential new hydrocarbon kitchens immediately offshore of Dunedin. 



\section{Summary and Conclusions}

The thesis aimed to improve our knowledge of the evolution of the Otago Shelf during the Neogene. This was achieved by mapping several Neogene horizons and by developing a 3D plate flexural model of the uplift on the shelf. In particular, this thesis has:

- Presented depth and isopach maps of six Neogene seismic horizons over an area that they had not previously been mapped.

- Documented the evolution of the Otago Shelf during Neogene time.

- Determined that the majority of fault movement on the Endeavour High occurred before 19 Ma with additional movement between $19 \mathrm{Ma}$ and $13.7 \mathrm{Ma}$.

- Confirmed that uplift on the Otago Shelf is not an artefact of a 2D seismic transect.

- Found that uplift on the Otago Shelf started after 19 Ma and stopped before 5 Ma.

- Established that uplift on the Otago Shelf can be explained by an Asthenospheric upwelling under a weak elastic plate.

- Shown that an asthenospheric upwelling explains the elevated heat flow around Dunedin and would result in enhanced maturity for nearby source rocks.

- Supported the hypothesis that the lithosphere on the Otago Shelf has been weakened compared to the surrounding lithosphere.

- Presented a model where asthenospheric upwelling has replaced a maximum $75 \mathrm{~km}$ thick column of mantle in an ellipse with an average radius of $71 \mathrm{~km}$, centred $25 \mathrm{~km}$ southwest of Dunedin. However the upwelling is likely smaller, depending on how much of the buoyancy is due to thermal expansion of the crust. 
- Proposed that the uplift is linked to the emplacement of the Dunedin Volcano because of the association in timing and the geophysical evidence for disturbance of the crust and mantle beneath Dunedin. However, the relationship of the Dunedin uplift to that of central Otago is unclear.

Consequently, our understanding of the evolution of the Otago Shelf during the Neogene has been improved. Future petroleum models will be able to incorporate a more accurate model of the overburden and consider scenarios where elevated heat flow enhances source rock maturity in the area. 


\section{References}

Adams CJ 1979. Age and origin of the Southern Alps. Royal Society of New Zealand Bulletin 18: 73-78.

Adams CJ 1981. Migration of late Cenozoic volcanism in the South Island of New Zealand and the Campbell Plateau. Nature 294(5837): 153-155.

Adams CJ, Cooper AF 1996. K-Ar age of a lamprophyre dike swarm near Lake Wanaka, west Otago, South Island, New Zealand. New Zealand Journal of Geology and Geophysics 39(1): 17-23.

Allen PA, Allen JR 1990. Basin analysis: principles and applications. Oxford, Blackwell scientific publications. $451 \mathrm{p}$.

Austral Pacific Energy Ltd 2006. Interpretation of the 2006 Whaler 2D seismic survey PEP38258. Unpublished open file Petroleum Report 3502, Ministry of Economic Development, Wellington, New Zealand. Pp. 44.

AWE New Zealand Ltd 2010. PEP 38259 (Barque) interpretation report. Unpublished open file Petroleum Report 4259, Ministry of Economic Development, Wellington, New Zealand. Pp. 50.

Batt GE, Braun J, Kohn BP, McDougall I 2000. Thermochronological analysis of the dynamics of the Southern Alps, New Zealand. Geological Society of America Bulletin 112(2): 250-266.

Bond CE, Gibbs AD, Shipton ZK, Jones S 2007. What do you think this is? Conceptual uncertainty in geoscience interpretation. GSA today 17(11): $4-10$.

Bourguignon S 2009. Lithospheric deformation at the South Island oblique collision, New Zealand. Unpublished PhD thesis, Victoria University of Wellington, Wellington, New Zealand. 303 p.

Box GEP, Draper NR 1987. Empirical model-building and response surfaces. Hoboken, NJ, John Wiley \& Sons. 669 p.

Brown LJ, Wilson DD, Moar NT, Mildenhall DC 1988. Stratigraphy of the late Quaternary deposits of the northern Canterbury Plains, New Zealand. New Zealand Journal of Geology and Geophysics 31(3): 305335.

Browne GH, Naish TR 2003. Facies development and sequence architecture of a late Quaternary fluvial-marine transition, Canterbury Plains and shelf, New Zealand: implications for forced regressive deposits. Sedimentary Geology 158(1): 57-86.

Brusova O 2011. Compaction of deep sea siliciclastic sediments based on log data. Unpublished MSc thesis, The University of Utah, Lake City, UT. 248 p. 
Byerly T 2010. AGU Grammar and Style Guide. Retrieved 4 April 2014, from publications.agu.org/files/2012/12/AGU_grammar_style.pdf

Cande SC, Kent DV 1995. Revised calibration of the geomagnetic polarity timescale for the Late Cretaceous and Cenozoic. Journal of Geophysical Research: Solid Earth 100(B4): 6093-6095.

Cande SC, Stock JM 2004. Pacific-Antarctic-Australia motion and the formation of the Macquarie Plate. Geophysical Journal International 157(1): 399-414.

Carter RM 1988. Post-breakup stratigraphy of the Kaikoura Synthem (Cretaceous-Cenozoic), continental margin, southeastern New Zealand. New Zealand Journal of Geology and Geophysics 31(4): 405-429.

Carter RM 2007. The role of intermediate-depth currents in continental shelfslope accretion: Canterbury Drifts, SW Pacific Ocean. Special Publications-Geological Society of London 276: 129-154.

Carter RM, Norris RJ 1976. Cainozoic history of southern New Zealand: an accord between geological observations and plate-tectonic predictions. Earth and Planetary Science Letters 31(1): 85-94.

Carter RM, Carter L, Davy B 1994. Seismic stratigraphy of the Bounty Trough, south-west Pacific Ocean. Marine and Petroleum Geology 11(1): 79-93.

Carter RM, Landis CA, Norris RJ, Bishop DG 1974. Suggestions towards a high-level nomenclature for New Zealand rocks. Journal of the Royal Society of New Zealand 4(1): 5-18.

Carter RM, Abbott ST, Fulthorpe CS, Haywick DW, Henderson RA 1991. Applications of global sea-level and sequence stratigraphic models in southern hemisphere Neogene strata from New Zealand. Special Publication of the International Association of Sedimentologists 2: 4165.

Carter RM, McCave IN, Richter C, Carter L, Hall IR, Shipboard Scientists 1999. Southwest Pacific gateways, sites 1119-1125. In: Richter C, McCave IN, Carter RM, Carter L, et al. ed. Proceedings of the Ocean Drilling Program, Initial Reports, 181. College Station, TX, Ocean Drilling Program. Pp. 1-80.

Charting Around New Zealand Group 2008. New Zealand Region Bathymetric Grid, $1: 4,000,000$ scale at $46^{\circ} \mathrm{S}$ on Mercator projection. NIWA Chart, Miscellaneous Series No. 85. Wellington, New Zealand, National Institute of Water and Atmospheric Research.

Cho WJ, Kwon S, Choi JW 2009. The thermal conductivity for granite with various water contents. Engineering Geology 107(3): 167-171.

Christensen NI, Mooney WD 1995. Seismic velocity structure and composition of the continental crust: A global view. Journal of Geophysical Research: Solid Earth 100(B6): 9761-9788. 
Constable R, Crookbain R 2011. A sequence stratigraphic study of the Great South Basin. Unpublished open file Petroleum Report 4348, Ministry of Economic Development, Wellington, New Zealand.

Cook RA, Sutherland R, Zhu H 1999. Cretaceous-Cenozoic geology and petroleum systems of the Great South Basin, New Zealand. Lower Hutt, New Zealand, Institute of Geological \& Nuclear Sciences. 191 p.

Coombs DS, White AJR, Hamilton D 1960. Age relations of the Dunedin Volcanic Complex and some paleogeographic implications - part I. New Zealand Journal of Geology and Geophysics 3(2): 325-336.

Coombs DS, Adams CJ, Roser BP, Reay A 2008. Geochronology and geochemistry of the Dunedin Volcanic Group, eastern Otago, New Zealand. New Zealand Journal of Geology and Geophysics 51(3): 195218.

Cooper AF, Barreiro BA, Kimbrough DL, Mattinson JM 1987. Lamprophyre dike intrusion and the age of the Alpine Fault, New Zealand. Geology 15(10): 941-944.

Davis TA 2004. Algorithm 832: UMFPACK V4. 3 - an unsymmetric-pattern multifrontal method. ACM Transactions on Mathematical Software 30(2): 196-199.

DeMets C, Gordon RG, Argus DF, Stein S 1994. Effect of recent revisions to the geomagnetic reversal time scale on estimates of current plate motions. Geophysical Research Letters 21(20): 2191-2194.

Doust H 2006. Petroleum Systems in New Zealand - an analogue approach. New Zealand Petroleum Conference Proceedings 2006, Wellington. Pp. 22 .

Expedition 317 Scientists 2011. Expedition 317 summary. In: Fulthorpe CS, Hoyanagi K, Blum P, Expedition 317 Scientists ed. Proceedings of the Integrated Ocean Drilling Program 317. Tokyo, Integrated Ocean Drilling Program Management International, Inc. Pp. 85.

Farrar E, Dixon JM 1984. Overriding of the Indian-Antarctic ridge: origin of Emerald Basin and migration of late Cenozoic volcanism in southern New Zealand and Campbell Plateau. Tectonophysics 104(3): 243-256.

Field BD, Browne GH 1989. Cretaceous and Cenozoic sedimentary basins and geological evolution of the Canterbury region, South Island, New Zealand. Basin Studies 2. Lower Hutt, New Zealand, New Zealand Geological Survey.

Field BD, Browne GH 1993. A subsiding platform adjacent to a plate boundary transpression zone: Neogene of Canterbury, New Zealand. South Pacific Sedimentary Basins; Sedimentary Basins of the World. Amsterdam, Elsevier Science Publishers. Pp. 271-278. 
Finn CA, Muller RD, Panter KS 2005. A Cenozoic diffuse alkaline magmatic province (DAMP) in the southwest Pacific without rift or plume origin. Geochemistry Geophysics Geosystems 6(2): Q02005.

Forsyth PJ 2001. Geology of the Waitaki area: Scale 1:250,000. Institute of Geological \& Nuclear Sciences 1:250,000 geological map 19. Lower Hutt, Institute of Geological \& Nuclear Sciences. Pp. 64.

Fowler CMR 2005. The solid earth: an introduction to global geophysics. 2 ed. Cambridge, UK, Cambridge University Press. 666 p.

Fulthorpe CS, Carter RM 1989. Test of seismic sequence methodology on a Southern Hemisphere passive margin: the Canterbury Basin, New Zealand. Marine and Petroleum Geology 6(4): 348-359.

Fulthorpe CS, Carter RM 1991. Continental-shelf progradation by sedimentdrift accretion. Geological Society of America Bulletin 103(2): 300-309.

Fulthorpe CS, Carter RM, Miller KG, Wilson J 1996. Marshall Paraconformity: a mid-Oligocene record of inception of the Antarctic Circumpolar Current and coeval glacio-eustatic lowstand? Marine and Petroleum Geology 13(1): 61-77.

Fulthorpe CS, Hoyanagi K, Blum P, IODP Expedition 317 Scientists 2011. IODP Expedition 317: Exploring the record of sea-level change off New Zealand. Scientific Drilling 317(12): 4-14.

Funnell R 2005. Petroleum modelling in PEP38258 Offshore Canterbury Basin New Zealand. Unpublished open file Petroleum Report 3504, Ministry of Economic Development, Wellington, New Zealand.

Funnell R, Chapman D, Allis R, Armstrong P 1996. Thermal state of the Taranaki basin, New Zealand. Journal of Geophysical Research: Solid Earth (1978-2012) 101(B11): 25197-25215.

Godfrey NJ, Davey F, Stern T, Okaya D 2001. Crustal structure and thermal anomalies of the Dunedin region, South Island, New Zealand. Journal of Geophysical Research. B. Solid Earth 106: 30,835-30,848.

Gorman AR, Hill MG, Orpin AR, Koons PO, Norris RJ, Landis CA, Allan THM, Johnstone T, Gray FL, Wilson D and others 2013. Quaternary shelf structures SE of the South Island, imaged by high-resolution seismic profiling. New Zealand Journal of Geology and Geophysics 56(2): 68-82.

Griffin AG 2009. Clipper-1 well sheet version 1a.02.2009. Petroleum Well Summary sheets. Lower Hutt, New Zealand, Institute of Geological and Nuclear Sciences.

Hart AW 2004. 2D Seismic interpretation PEP38258. Unpublished open file Petroleum Report 3272, Ministry of Economic Development, Wellington, New Zealand.

Haskell TR 2000. Structural and petroleum systems review PEP38254, Canterbury Basin, South Island, New Zealands. Unpublished open file 
Petroleum Report 1762, Ministry of Economic Development, Wellington, New Zealand.

Hatherton T, Leopard AE 1964. The densities of New Zealand rocks. New Zealand Journal of Geology and Geophysics 7(3): 605-625.

Hawkes PW, Mound DG, Spicer PJ 1985. Clipper-1 evaluation report PPL 38022. Unpublished open file Petroleum Report 1078, Ministry of Economic Development, Wellington, New Zealand.

Herzer RH 1979. Submarine slides and submarine canyons on the continental slope off Canterbury, New Zealand. New Zealand Journal of Geology and Geophysics 22(3): 391-406.

Herzer RH 1981. Late Quaternary stratigraphy and sedimentation of the Canterbury continental shelf, New Zealand. New Zealand Oceanographic Institute 89: 1-79.

Hoernle K, White JDL, Van Den Bogaard P, Hauff F, Coombs DS, Werner R, Timm C, Garbe-Schonberg D, Reay A, Cooper AF 2006. Cenozoic intraplate volcanism on New Zealand: Upwelling induced by lithospheric removal. Earth and Planetary Science Letters 248(1): 350-367.

Hoke L, Poreda R, Reay A, Weaver SD 2000. The subcontinental mantle beneath southern New Zealand, characterised by helium isotopes in intraplate basalts and gas-rich springs. Geochimica et Cosmochimica Acta 64(14): 2489-2507.

Holt WE, Stern TA 1991. Sediment loading on the western platform of the New Zealand continent: Implications for the strength of a continental margin. Earth and Planetary Science Letters 107(3): 523-538.

Kamp PJJ 1987. Age and origin of the New Zealand Orocline in relation to Alpine Fault movement. Journal of the Geological Society 144(4): 641652.

Killops SD, Cook RA, Sykes R, Boudou JP 1997. Petroleum potential and oilsource correlation in the Great South and Canterbury Basins. New Zealand Journal of Geology and Geophysics 40(4): 405-423.

King PR 2000a. New Zealand's changing configuration in the last 100 million years: plate tectonics, basin development, and depositional setting. 2000 New Zealand Petroleum Conference Proceedings, Christchurch Convention Centre, New Zealand. Pp. 132-146.

King PR 2000b. Tectonic reconstructions of New Zealand: 40 Ma to the present. New Zealand Journal of Geology and Geophysics 43(4): 611638.

King PR, Naish TR, Browne GH, Field BD, Edbrooke SW 1999. Cretaceous to Recent sedimentary patterns in New Zealand. Institute of Geological and Nuclear Sciences folio series 1, version 1999.1. Lower Hutt, New Zealand. 
Kirk RM, Tierney BW 1978. Nearshore sediment movement around the Port of Timaru. Proceedings 7th Biennial Conference, New Zealand Harbour Engineers Association, Dunedin. Pp. 80-140.

Landis CA, Campbell HJ, Begg JG, Mildenhall DC, Paterson AM, Trewick SA 2008. The Waipounamu Erosion Surface: questioning the antiquity of the New Zealand land surface and terrestrial fauna and flora. Geological Magazine 145(02): 173-197.

Lebrun J-F, Lamarche G, Collot J-Y 2003. Subduction initiation at a strikeslip plate boundary: The Cenozoic Pacific-Australian plate boundary, south of New Zealand. Journal of Geophysical Research: Solid Earth 108(B9): 1-18.

Leitner B, Eberhart-Phillips D, Anderson H, Nabelek JL 2001. A focused look at the Alpine Fault, New Zealand: Seismicity, focal mechanisms, and stress observations. Journal of Geophysical Research: Solid Earth 106(B2): 2193-2220.

LeMasurier WE, Landis CA 1996. Mantle-plume activity recorded by low-relief erosion surfaces in West Antarctica and New Zealand. Geological Society of America Bulletin 108(11): 1450-1466.

Lu H 2004. Global and local controls on depositional cyclicity: Canterbury Basin, New Zealand. Unpublished PhD thesis, University of Texas at Austin, Austin, TX. 255 p.

Lu H, Fulthorpe CS, Mann P 2003. Three-dimensional architecture of shelfbuilding sediment drifts in the offshore Canterbury Basin, New Zealand. Marine Geology 193(1): 19-47.

Lyon-Caen H, Molnar P 1989. Constraints on the deep structure and dynamic processes beneath the Alps and adjacent regions from an analysis of gravity anomalies. Geophysical Journal International 99(1): 19-32.

Magoon LB, Dow WG 1994. The petroleum system: from source to trap. AAPG Memoir 60: 3-24.

Mayes CL, Lawver LA, Sandwell DT 1990. Tectonic history and new isochron chart of the South Pacific. Journal of Geophysical Research: Solid Earth 95(B6): 8543-8567.

Melhuish A, Holbrook WS, Davey F, Okaya DA, Stern T 2005. Crustal and upper mantle seismic structure of the Australian plate, South Island, New Zealand. Tectonophysics 395(1): 113-135.

Mellanby J 2013. New Zealand Journal of Geology and Geophysics: Instruction for Authors. Retrieved 4 April 2014, from http://www.royalsociety.org.nz/publications/journals/nzjg/instructionsfor-authors/

Mogg WG 2007. Wherry and Caravel seismic survey and associated seismic reprocessing: Final intepretation report. Unpublished open file 
Petroleum Report 3884, Ministry of Economic Development, Wellington, New Zealand.

Mogg WG 2008. The petroleum potential of the offshore Canterbury Basin : insights from petroleum systems modelling. PESA Eastern Australasian Basins Symposium III, Sydney, Australia. Pp. 14-17.

Mogg WG 2010. Waka 3D interpretation report; Carrack and Caraval Prospects. Unpublished open file Petroleum Report 4188, Ministry of Economic Development, Wellington, New Zealand.

Mogg WG, Aurisch K, O'Leary R, Pass GP 2008. Offshore Canterbury Basin beyond the shelf edge. New Zealand Petroleum Conference Proceedings 2008. Auckland, New Zealand.

Mortimer N, Davey FJ, Melhuish A, Yu J, Godfrey NJ 2002. Geological interpretation of a deep seismic reflection profile across the Eastern Province and Median Batholith, New Zealand: crustal architecture of an extended Phanerozoic convergent orogeny. New Zealand Journal of Geology and Geophysics 45(3): 349-363.

Mound DG, Pratt DN 1984. Interpretation and prospectivity of PPL 38202 Canterbury Basin, New Zealand. Unpublished Petroleum Report 1021, Ministry of Economic Development, Wellington, New Zealand.

New Zealand Oil and Gas Ltd 2012. PEP 38259 interpretation report. Unpublished open file Petroleum Report 4609, Ministry of Economic Development, Wellington, New Zealand.

Norris RJ, Carter RM, Turnbul IM 1978. Cenozoic sedimentation in basins adjacent to a major continental transform boundary in Southern New Zealand. Journal of the Geological Society of London 135(2): 191-206.

Osterberg EC 2006. Late Quaternary (marine isotope stages 6-1) seismic sequence stratigraphic evolution of the Otago continental shelf, New Zealand. Marine Geology 229(3): 159-178.

Panter KS, Blusztajn J, Hart SR, Kyle PR, Esser R, McIntosh WC 2006. The origin of HIMU in the SW Pacific: Evidence from intraplate volcanism in southern New Zealand and subantarctic islands. Journal of Petrology 47(9): 1673-1704.

Pérez-Gussinyé M, Metois M, Fernández M, Vergés J, Fullea J, Lowry AR 2009. Effective elastic thickness of Africa and its relationship to other proxies for lithospheric structure and surface tectonics. Earth and Planetary Science Letters 287(1): 152-167.

Perry S 1991. PPL3 8251 Offshore Canterbury seismic interpretation report. Unpublished open file Petroleum Report 1783, Ministry of Economic Development, Wellington, New Zealand.

Polat FO 2012. Core-seismic correlation and sequence stratigraphy at IODP Expedition 317 drillsites, Canterbury Basin, New Zealand. Unpublished MSc thesis, University of Texas at Austin, Austin, TX. 101 p. 
Polson D, Curtis A 2010. Dynamics of uncertainty in geological interpretation. Journal of the Geological Society 167(1): 5-10.

Punyasena SW, Jaramillo C, de la Parra F, Du Y 2012. Probabilistic correlation of single stratigraphic samples: A generalized approach for biostratigraphic data. AAPG bulletin 96(2): 235-244.

Rankey EC, Mitchell JC 2003. That's why it's called interpretation: Impact of horizon uncertainty on seismic attribute analysis. The Leading Edge 22(9): 820-828.

Reilly WI 1972. New Zealand gravity map series. New Zealand Journal of Geology and Geophysics 15(1): 3-15.

Samuel SP 2011. Depositional History of Paleocene Sediments in the Offshore Canterbury Basin, New Zealand. Unpublished MSc thesis, Victoria University of Wellington, Wellington, New Zealand. 164 p.

Schlumberger Ltd 2013. Petrel Software Platform, 2013. Software package for oil and gas exploration and production. Houston, Texas, United States, Schlumberger Information Solutions.

Sheriff RE, Geldart L 1995. Exploration seismology. 2 ed. Cambridge, United Kingdom, Cambridge University Press. 628 p.

Spicer PJ 1986. A review of remaining prospectivity and recommendations for relinquishment. PPL38202 and PPL38203. Unpublished open file Petroleum Report 1199, Ministry of Economic Development, Wellington, New Zealand.

Sprung P, Schuth S, Munker C, Hoke L 2007. Intraplate volcanism in New Zealand: the role of fossil plume material and variable lithospheric properties. Contributions to Mineralogy and Petrology 153(6): 669-687.

Stern TA, Quinlan GM, Holt WE 1992. Basin formation behind an active subduction zone: three-dimensional flexural modelling of Wanganui Basin, New Zealand. Basin Research 4(3-4): 197-214.

Stock J, Molnar P 1982. Uncertainties in the relative positions of the Australia, Antarctica, Lord Howe, and Pacific plates since the Late Cretaceous. Journal of Geophysical Research: Solid Earth 87(B6): 46974714 .

Storey BC, Leat PT, Weaver SD, Pankhurst RJ, Bradshaw JD, Kelley S 1999. Mantle plumes and Antarctica-New Zealand rifting: evidence from midCretaceous mafic dykes. Journal of the Geological Society 156(4): 659671.

Sutherland R 1995. The Australia-Pacific boundary and Cenozoic plate motions in the SW Pacific: Some constraints from Geosat data. Tectonics 14(4): 819-831.

Sutherland R 1999. Basement geology and tectonic development of the greater New Zealand region: an interpretation from regional magnetic data.

Tectonophysics 308(3): 341-362. 
Sutherland R, Browne GH 2003. Canterbury Basin offers potential on South Island, New Zealand. Oil and Gas Journal 101: 45-50.

Sutherland R, Viskovic GPD, Bache F, Stagpoole VM, Collot J, Rouillard P, Hashimoto T, Hackney R, Higgins K, Rollet N and others 2012. Compilation of seismic reflection data from the Tasman Frontier region, southwest Pacific. Institute of Geological and Nuclear Sciences science report 2012/01. Lower Hutt, Institute of Geological and Nuclear Sciences. Pp. 72.

Sykes R, Funnell RH 2002. Petroleum source rock potential and generation history in the offshore Canterbury Basin. unpublished openfile petroleum report 2707, Ministry of Economic Development, Wellington, New Zealand.

Tap Oil Ltd 2006. Geochem source migration. Unpublished open file Petroleum Report 3388, Ministry of Economic Development, Wellington, New Zealand.

Timm C, Hoernle K, Werner R, Hauff F, den Bogaard PV, White J, Mortimer N, Garbe-Schonberg D 2010. Temporal and geochemical evolution of the Cenozoic intraplate volcanism of Zealandia. Earth-Science Reviews 98(1-2): 38-64.

Tippett JM, Kamp PJJ 1993a. The role of faulting in rock uplift in the Southern Alps, New Zealand. New Zealand Journal of Geology and Geophysics 36(4): 497-504.

Tippett JM, Kamp PJJ 1993b. Fission track analysis of the late Cenozoic vertical kinematics of continental Pacific crust, South Island, New Zealand. Journal of Geophysical Research: Solid Earth 98(B9): 1611916148 .

Van Rossum G, Drake FL 1995. Python reference manual. Amsterdam, Netherlands, Centrum voor Wiskunde en Informatica Amsterdam. 196 p.

Van Wees JD, Cloetingh SAPL 1994. A finite-difference technique to incorporate spatial variations in rigidity and planar faults into 3-D models for lithospheric flexure. Geophysical Journal International 117(1): 179-195.

Walcott RI 1998. Modes of oblique compression: Late Cenozoic tectonics of the South Island of New Zealand. Reviews of Geophysics 36(1): 1-26.

Watts AB 1992. The effective elastic thickness of the lithosphere and the evolution of foreland basins. Basin Research 4(3-4): 169-178.

Watts AB 2001. Isostasy and Flexure of the Lithosphere. Cambridge, United Kingdom, Cambridge University Press. 458 p.

Weaver SD, Storey BC, Pankhurst RJ, Mukasa SB, DiVenere VJ, Bradshaw JD 1994. Antarctica-New Zealand rifting and Marie Byrd Land 
lithospheric magmatism linked to ridge subduction and mantle plume activity. Geology 22(9): 811-814.

Wellman P, Cooper A 1971. Potassium-argon age of some New Zealand lamprophyre dikes near the Alpine Fault. New Zealand Journal of Geology and Geophysics 14(2): 341-350.

Wickert AD 2014. in press. Lithospheric Flexure and Earth-Surface Processes: 1. Rapid Solutions with Nonuniform Elastic Thickness. Colorado, United States, University of Colorado Boulder.

Wilson IR 1985. Well completion report Galleon-1. PPL 38203. Unpublished open file Petroleum Report 1146, Ministry of Economic Development, Wellington, New Zealand. 


\section{Appendix 1. Seismic and wells used in this thesis}

\begin{tabular}{lll}
\hline Survey & Year & Operator \\
\hline Hunt A & 1971 & Hunt International Petroleum Co NZ \\
Hunt B & 1972 & Hunt International Petroleum Co NZ \\
Hunt F & 1972 & Hunt International Petroleum Co NZ \\
CB82 & 1982 & Shell BP Todd Canterbury Services Ltd \\
CB84 & 1984 & Shell BP Todd Canterbury Services Ltd \\
S96R & 1996 & GNS \\
ANZ & 2000 & Anschutz New Zealand Corporation \\
EW00-01 & 2000 & University of Texas Institute for Geophysics \\
DUN06 & 2006 & Crown Minerals \\
Carrack & 2006 & Origin \\
Caravel & 2007 & Origin \\
Wherry & 2007 & Origin \\
Barque & 2009 & AWE \\
Waka 3D & 2009 & Origin \\
Waka tie line & 2009 & Origin \\
Punt & 2009 & Origin \\
TL-BT10 & 2010 & Crown \\
ACB11 & 2011 & Anadarko \\
\hline
\end{tabular}

Table A1.1: Seismic surveys used in this thesis. 


\begin{tabular}{|c|c|c|c|c|}
\hline Name & Date & $\begin{array}{l}\text { Depth } \\
(\mathrm{m})\end{array}$ & Operator & Status \\
\hline Endeavour-1 & 1970 & 2741 & $\begin{array}{l}\text { BP Shell Aquitaine Todd } \\
\text { Petroleum Developments }\end{array}$ & $\mathrm{P} \& \mathrm{~A}$ \\
\hline Resolution-1 & 1975 & 1963 & BP Shell Todd Canterbury & $\mathrm{P} \& \mathrm{~A}$ \\
\hline $\begin{array}{l}\text { Takapu- } \\
1 / 1 \mathrm{~A}\end{array}$ & 1978 & 890 & Hunt International Petroleum & $\mathrm{P} \& \mathrm{~A}$ \\
\hline Clipper-1 & 1984 & 4742 & BP Shell Todd Canterbury & $\begin{array}{l}\mathrm{P} \& \mathrm{~A} \text { gas } \\
\text { condensate shows }\end{array}$ \\
\hline Galleon-1 & 1985 & 3086 & BP Shell Todd Canterbury & $\begin{array}{l}\text { P\&A gas } \\
\text { condensate } \\
\text { discovery }\end{array}$ \\
\hline ODP 1119 & 1998 & 195 & Ocean Drilling Program & $\mathrm{P} \& \mathrm{~A}$ \\
\hline Cutter-1 & 2006 & 2630 & Tap Oil & $\mathrm{P} \& \mathrm{~A}$ \\
\hline IODP U1351 & 2010 & 1163 & $\begin{array}{l}\text { Integrated Ocean Drilling } \\
\text { Program }\end{array}$ & $\mathrm{P} \& \mathrm{~A}$ \\
\hline IODP U1352 & 2010 & 2282 & $\begin{array}{l}\text { Integrated Ocean Drilling } \\
\text { Program }\end{array}$ & $\mathrm{P} \& \mathrm{~A}$ \\
\hline IODP U1353 & 2010 & 710 & $\begin{array}{l}\text { Integrated Ocean Drilling } \\
\text { Program }\end{array}$ & $\mathrm{P} \& \mathrm{~A}$ \\
\hline IODP U1354 & 2010 & 509 & $\begin{array}{l}\text { Integrated Ocean Drilling } \\
\text { Program }\end{array}$ & $\mathrm{P} \& \mathrm{~A}$ \\
\hline
\end{tabular}

Table A1.2: Exploration and research wells used in this thesis. Depth is total vertical depth from kelly bushing, and plugged and abandoned wells are denoted with P\&A 


\section{Appendix 2. Data for time-depth correlation}

\begin{tabular}{|c|c|c|c|c|}
\hline $\begin{array}{l}\text { Sequence } \\
\text { Boundary }\end{array}$ & $\begin{array}{l}\text { Two-way } \\
\text { time } \\
\text { (ms) }\end{array}$ & $\begin{array}{l}\text { Regional } \\
\text { depth } \\
\text { function } \\
\text { (mbsf) }\end{array}$ & $\begin{array}{l}\text { Synthetic } \\
\text { seismogram } \\
(\text { mbsf) }\end{array}$ & $\begin{array}{l}\text { Core } \\
\text { observations } \\
(\mathrm{mbsf})\end{array}$ \\
\hline Reference: & Lu (2004) & $\begin{array}{l}\text { Brusova } \\
(2011)\end{array}$ & $\begin{array}{l}\text { Polat } \\
(2012)\end{array}$ & Polat (2012) \\
\hline U19 & 20.5 & 16.1 & 15.3 & 15.955 \\
\hline U18 & 37.5 & 29.6 & 33.1 & 29.51 \\
\hline U17 & 63 & 50.1 & 54.1 & $\mathbf{5 2 . 2 6}$ \\
\hline U16 & 80 & 63.9 & 67.8 & 70.33 \\
\hline $\mathrm{U} 15$ & 106 & 85.2 & 90.2 & 88.86 \\
\hline U14 & 127 & 102.6 & 107.9 & - \\
\hline U13 & 163.5 & 133.4 & 138.7 & 144.13 \\
\hline $\mathrm{U} 12$ & 201.5 & 166 & 168.3 & 171.42 \\
\hline U11 & 232 & 192.8 & 195.8 & - \\
\hline U10 & 278 & 234 & 235.7 & - \\
\hline U9 & 355.5 & 305.5 & 307.5 & - \\
\hline U8 & 437 & 384.3 & 386.5 & - \\
\hline $\mathrm{U} 7$ & 638 & 592.9 & 582.7 & - \\
\hline U6 & 865 & 851 & 804.8 & - \\
\hline U5 & 997 & 1008.5 & 933.9 & - \\
\hline
\end{tabular}

Table A2.1: Available data for time-depth correlation at well U1351 of the IODP (Integrated Ocean Drilling Project). The bold numbers were used in this thesis because they were the best available for their respective sequence boundaries. Sequence boundaries from $\mathrm{Lu}$ (2004)'s have depth values from Brusova (2011)'s regional depth function and Polat (2012)'s synthetic seismograms and core observations. Depths are listed in metres below sea floor (mbsf). 


\begin{tabular}{|c|c|c|c|c|}
\hline $\begin{array}{l}\text { Sequence } \\
\text { Boundary }\end{array}$ & $\begin{array}{l}\text { Two-way } \\
\text { time (ms) }\end{array}$ & $\begin{array}{l}\text { Regional } \\
\text { depth } \\
\text { function } \\
(\mathrm{m})\end{array}$ & $\begin{array}{l}\text { Synthetic } \\
\text { seismogram } \\
(\mathrm{m})\end{array}$ & $\begin{array}{l}\text { Observed } \\
\text { from core }(\mathrm{m})\end{array}$ \\
\hline Reference: & Lu (2004) & $\begin{array}{l}\text { Brusova } \\
(2011)\end{array}$ & $\begin{array}{l}\text { Polat } \\
(2012)\end{array}$ & Polat (2012) \\
\hline U19 & 87 & 68.6 & 73.7 & 62.15 \\
\hline U18 & 175 & 141.4 & 150 & 147.22 \\
\hline U17 & 234 & 192.46 & 196.8 & 207.04 \\
\hline U16 & 292 & 244.6 & 245 & 246.59 \\
\hline U15 & 472 & 420.1 & 403.4 & 423.84 \\
\hline U14 & 491 & 440 & 419.5 & 453.12 \\
\hline U13 & 539 & 491.7 & - & - \\
\hline U11 & 770 & 772.5 & - & - \\
\hline U9 & 924 & 998.5 & - & - \\
\hline U8 & 1043 & 1201.6 & - & - \\
\hline U7 & 1124 & 1356.7 & - & - \\
\hline U6 & 1241 & 1606.2 & - & - \\
\hline MP & 1380 & - & - & 1853 \\
\hline
\end{tabular}

Table A2.2: Available data for time-depth correlation at well U1352 of the IODP (Integrated Ocean Drilling Project) The bold numbers were used in this thesis because they were the best available for their respective sequence boundary. Sequence boundaries from $\mathrm{Lu}$ (2004)'s have depth values from Brusova (2011)'s regional depth function and Polat (2012)'s synthetic seismograms and core observations. Depths are listed in metres below sea floor (mbsf). 


\section{Appendix 3. Description of interpreted units}

\section{A3.1 T70}

Bounding surfaces: Top T60 and Top T70 (Constable \& Crookbain 2011)

Assigned absolute age: 46-31 Ma (Expedition 317 Scientists 2011)

Colour: Green

Well Data: U1352, Clipper-1, Galleon-1, Resolution-1, Endeavour-1, Takapu-1A, and Cutter-1

This sequence has low-to-moderate amplitudes with moderate continuity seismic reflections. The top of this sequence is the Marshall Unconformity, which was most recently penetrated by IODP well U1352 and assigned an age of 30.1-32.0 Ma. Top T70 is outside the Neogene interval but was included in this thesis because it serves as the lower bounding surface of the sequences deposited during the Neogene and will be used in Chapter 3.

\section{A3.2 N10}

Bounding surfaces: Top T70 to Top N10

Assigned absolute age: 31-19 Ma (Expedition 317 Scientists 2011)

Colour: Yellow

Well Data: U1352, Clipper-1, Galleon-1, Resolution-1, Endeavour-1, Takapu-1A, and Cutter-1

This sequence has low-to-moderate amplitudes but highly continuous reflections. It is cut by numerous younger large submarine canyons and higherorder erosional events (Constable \& Crookbain 2011). The top of the sequence corresponds to the regional downlap surface above the Marshall Unconformity. It has been almost completely eroded on the modern slope.

This predominantly limestone unit is a distinct basin-wide horizon that was deposited during bathyal conditions in a flooded basin following the Marshall Unconformity. Constable \& Crookbain (2011) previously mapped it over the southern Canterbury Basin. It has been given various ages, but the 
IODP U1352 well most recently intersected it, where it was dated at $19 \mathrm{Ma}$ (Expedition 317 Scientists 2011).

\section{A3.3 N20}

Bounding surfaces: Top N10 to Top N20

Assigned absolute age: 19-13.7 Ma (Griffin 2009)

Colour: Light green

Well Data: Clipper-1

The base of this sequence is thick and chaotic with high seismic amplitudes over much of the shelf. The top contains high-amplitude continuous reflections on the upper-to-middle slope (Lu 2004). This sequence covers the first major progradation of the continental shelf in the Neogene Period. The earliest drifts are located in this sequence ( $\mathrm{Lu}$ 2004). It downlaps onto the Marshall Unconformity, which has eroded its paleoshelf edges in much of the central basin. The sequence onlaps onto both the Endeavour High and the uplift around the Otago Peninsula. Deposition covers a timespan that includes the start of strike-slip movement on the Alpine Fault, uplift on the Otago Shelf, and a Middle Miocene climatic cooling period from 14.5-13 Ma.

\section{A3.4 N30}

Bounding surfaces: Top N20 to Top N30

Assigned absolute age: 13.7-13 Ma (Griffin 2009)

Colour: Purple

Well Data: Clipper-1

This sequence, which is very similar to N20, contains high-amplitude continuous reflections on the upper-to-middle slope ( $\mathrm{Lu} \mathrm{2004).} \mathrm{It} \mathrm{was} \mathrm{only}$ penetrated at Clipper-1 and has also had its paleoshelf eroded in the central basin. It terminates at the mid-Miocene climatic warming from 13-12.5 Ma (Lu 2004). 


\section{A3.5 N50}

Bounding surfaces: Top N30 to Top N50

Assigned absolute age: 13-11.3 Ma (Expedition 317 Scientists 2011)

Colour: Orange

Well Data: Clipper-1, and U1351

This sequence comprises continuous reflections on the upper-middle slope with higher amplitudes than the sequence below. This sequence is the first to display a paleoslope in the central basin. Large $U$ shaped canyons cut this sequence, particularly near the Endeavour High. The top of this sequence occurred when convergence on the Southern Alps became significant, possibly marking a change in sedimentation from subsidence-driven to sediment-inputdriven.

\section{A3.6 N80}

Bounding surfaces: Top N50 to Top N80

Assigned absolute age: 11.3-5 Ma (Expedition 317 Scientists 2011)

Colour: Aqua

Well Data: Clipper-1, U1351, U1352, and U1353

Amplitudes in N80 are lower than those below it. Reflections are continuous with distinct breakpoints and sigmoid internal reflections ( $\mathrm{Lu}$ 2004).The paleoshelves of N80 are onlapped by overlying reflections with truncation or toplap beneath their outer paleoshelves near breakpoints. A distinctive characteristic of N80 is the less frequent channel and canyon incision of paleoshelves and slopes, which are mainly smooth surfaces (Lu 2004).

This sequence is the youngest that correlates with convergence on the Southern Alps, and also covers a period where convergence increased from a rate of $2 \mathrm{~mm} / \mathrm{yr}$ in the period before this sequence to an average of $4.5 \mathrm{~mm} / \mathrm{yr}$ after it (Lu 2004), pointing toward a major increase in sediment supply. This sequence terminates during a period of climatic warming from 5-4 Ma. 


\section{A3.7 N100}

Bounding surfaces: Top N80 to Top N100

Assigned absolute age: 5-3.65 Ma (Expedition 317 Scientists 2011)

Colour: Light orange

Well Data: Clipper-1, U1351, U1352, U1353, and U1354

This sequence has lower amplitude, higher frequency, and more continuous reflections than above and below, giving it a washed-out appearance. Its reflections are more continuous and parallel than above, with common gas washout and channel down-cutting. During deposition of this sequence, convergence on the Southern Alps increased from $4.5 \mathrm{~mm} / \mathrm{yr}$ during N100 to $7.5 \mathrm{~mm} / \mathrm{yr}$, indicating increased erosion and sediment supply. In contrast to N20 through N50, this sequence does not appear to onlap onto the Otago Peninsula uplift.

\section{A3.8 N120}

Bounding surfaces: Top N100-Seafloor

Assigned absolute age: 3.65-0 Ma (Expedition 317 Scientists 2011)

Well Data: Clipper-1, U1351, U1352, U1353, U1354, and ODP-1119C

Sequence N120 includes everything above Top N100. This interval displays a higher amplitude and lower frequency than underlying sequences. Reflections are a mix of parallel and chaotic and are often incised by U- or V-shaped canyons. Internal sequence boundaries have oblique geometries and have more pronounced rollover than sequences below ( $\mathrm{Lu} 2004$ ). 


\section{Appendix 4. Large Maps}

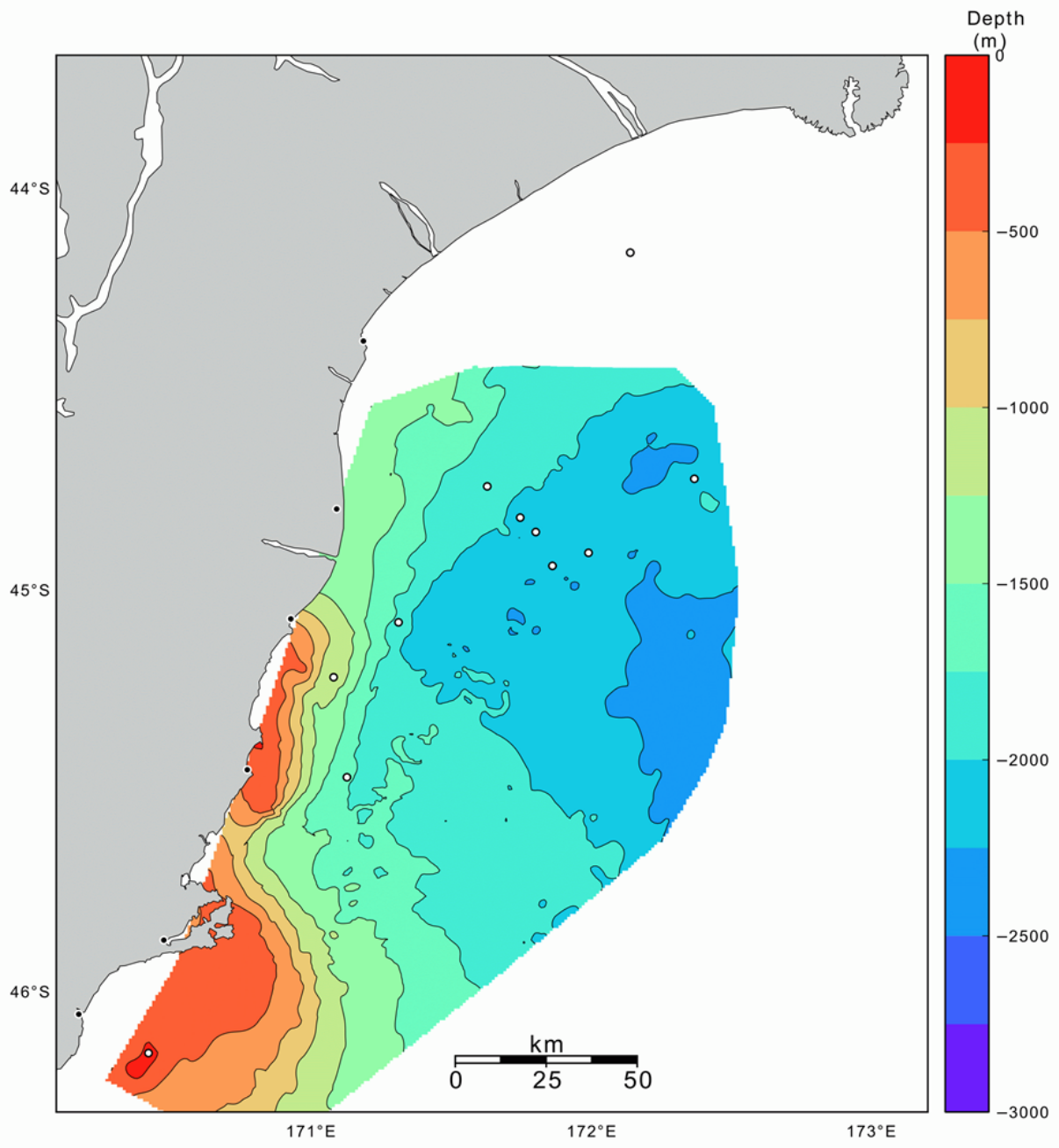

Fig. A5.1: Top T70 structure map. This horizon is 31 Ma at Clipper-1. The legend to the right shows the depth in metres from mean sea level. The black circles show the wells labelled in Fig. 1.1. 


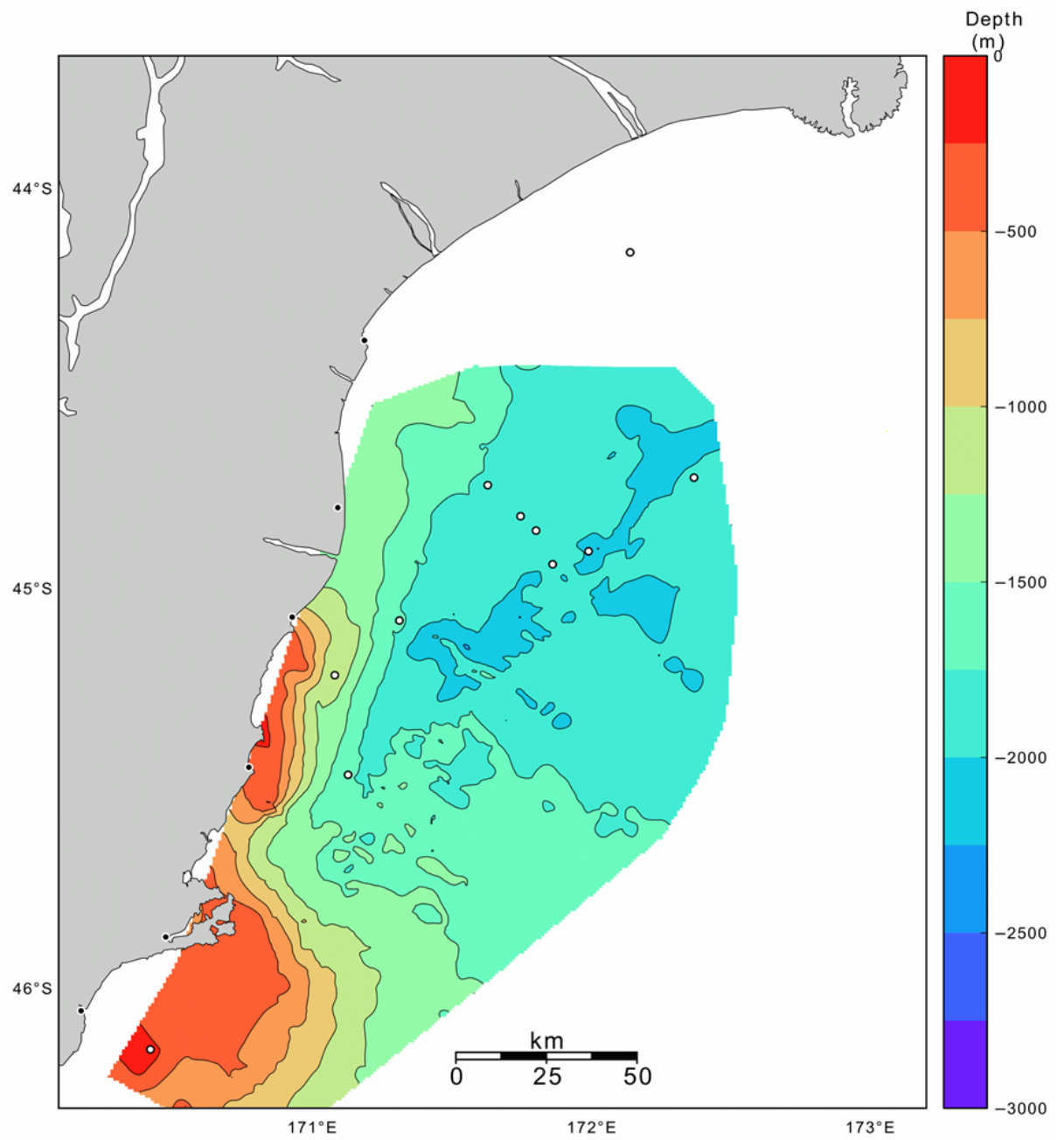

Fig. A5.2: Top N10 structure map. This horizon is 11 Ma at Clipper-1. The legend to the right shows the depth in metres from mean sea level. The black circles show the wells labelled in Fig. 1.1. 


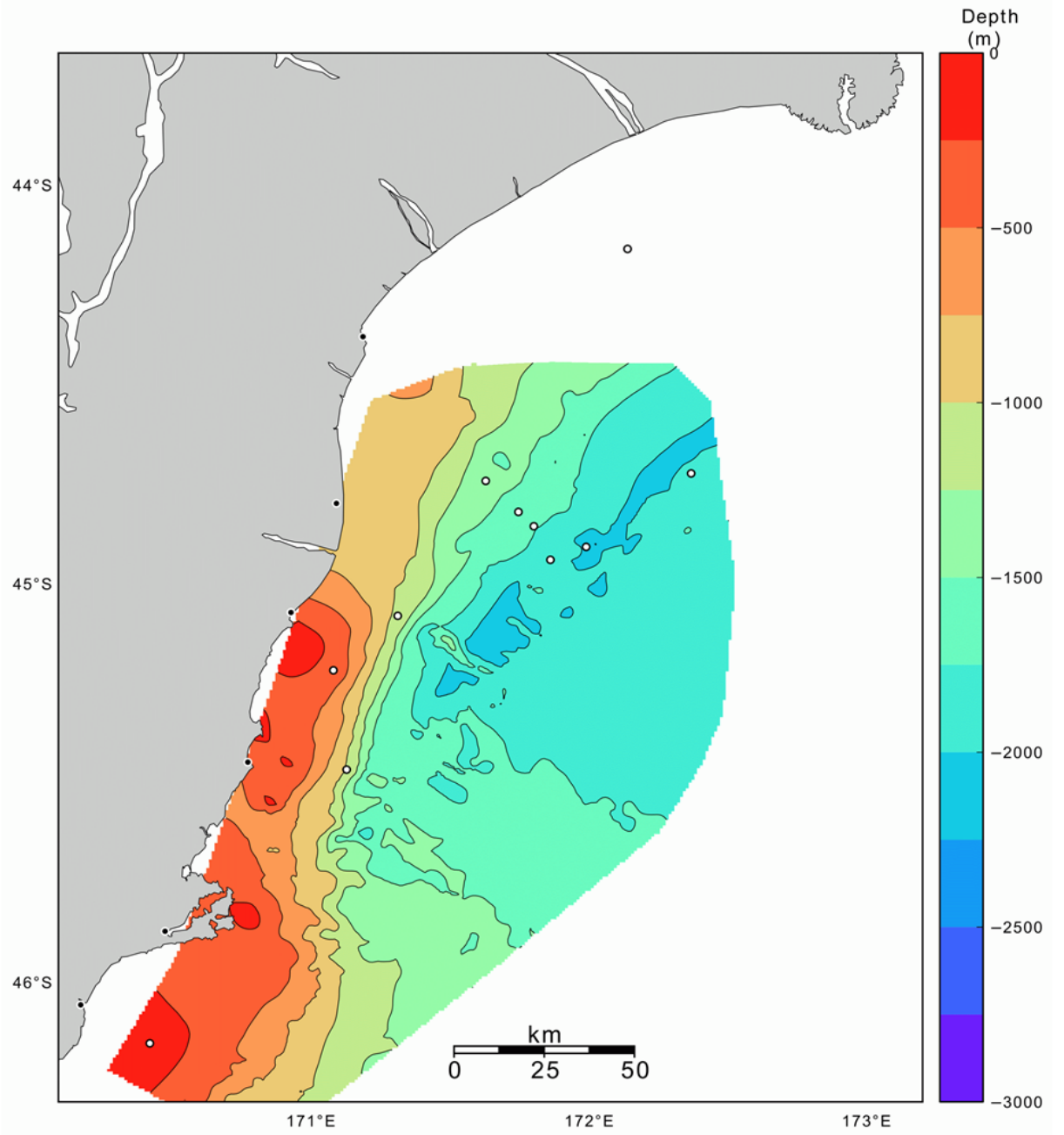

Fig. A5.3: Top N20 structure map. This horizon is $13.7 \mathrm{Ma}$ at IODP U1352. The legend to the right shows the depth in metres from mean sea level. The black circles show the wells labelled in Fig. 1.1. 


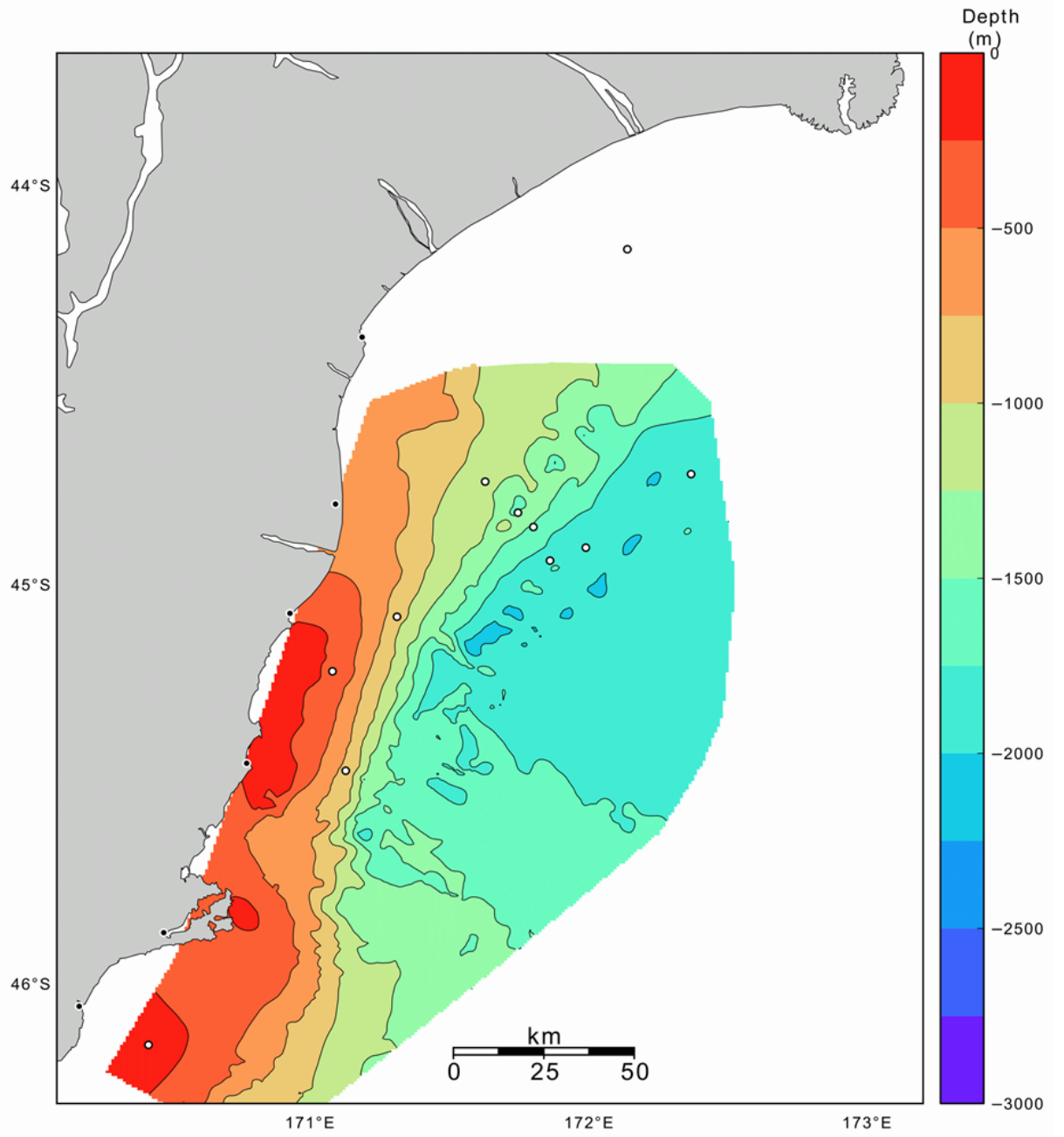

Fig. A5.4: Top N30 structure map. This horizon is 13 Ma at IODP U1352. The legend to the right shows the depth in metres from mean sea level. The black circles show the wells labelled in Fig. 1.1. 


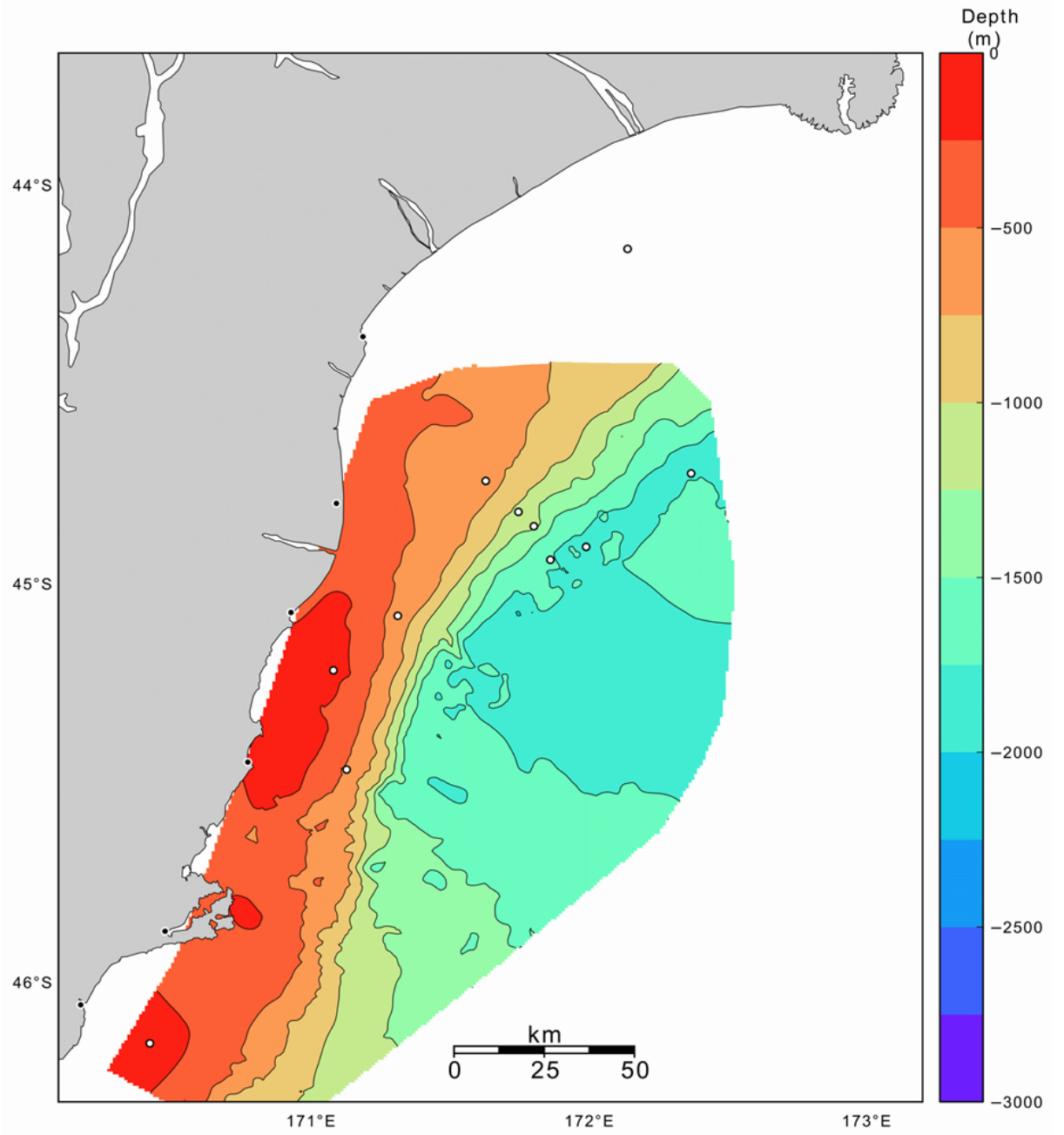

Fig. A5.5: Top N50 structure map. This horizon is $11.3 \mathrm{Ma}$ at IODP U1352. The legend to the right shows the depth in metres from mean sea level. The black circles show the wells labelled in Fig. 1.1. 


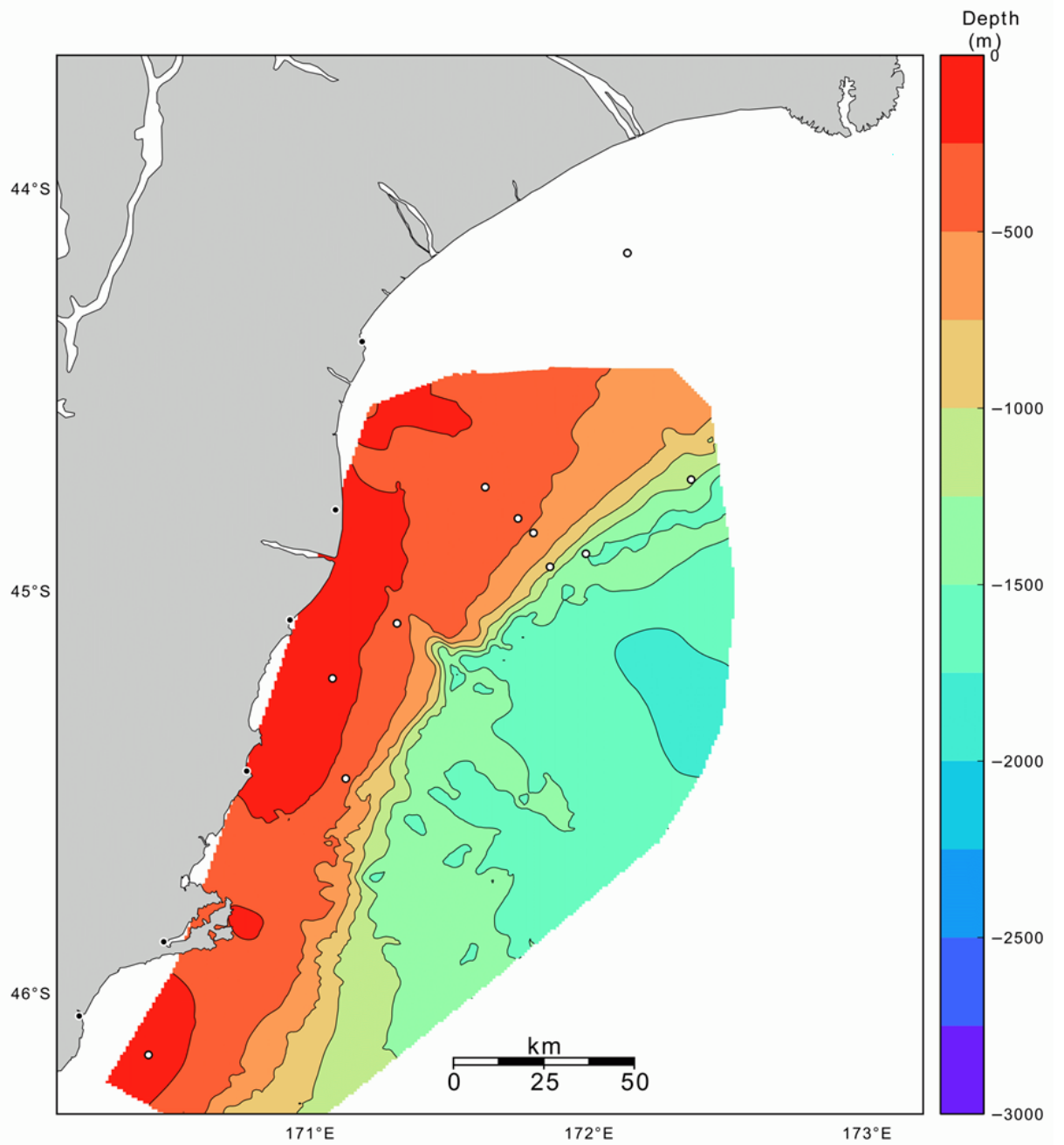

Fig. A5.6: Top N80 structure map. This horizon is 5 Ma at IODP U1352. The legend to the right shows the depth in metres from mean sea level. The black circles show the wells which are labelled in Fig. 1.1. 


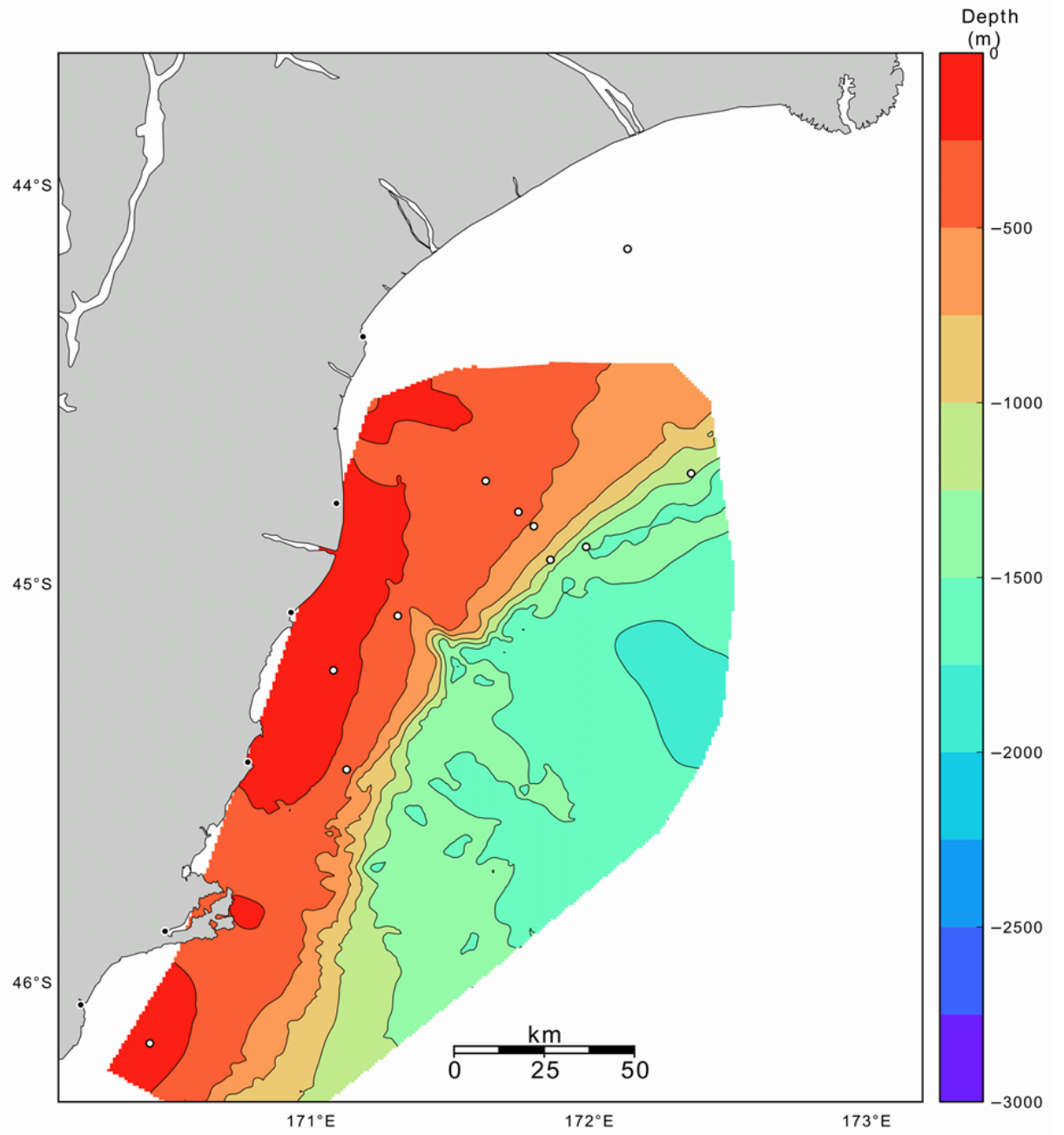

Fig. A5.7 : Top N80 structure map. This horizon is 5 Ma old at IODP U1352. The legend to the right shows the depth in metres from mean sea level. The black circles show the wells labelled in Fig. 1.1. 


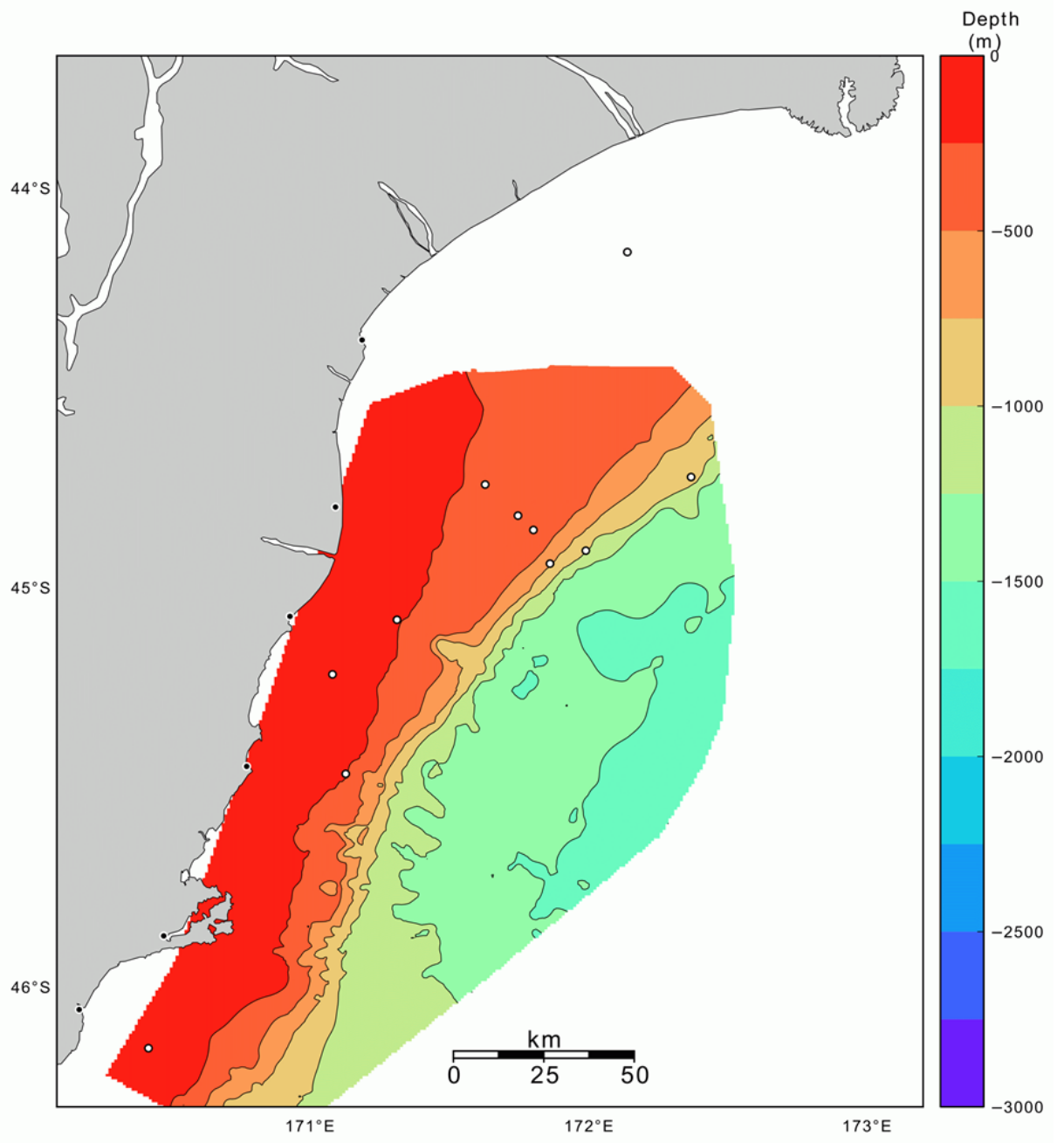

Fig. A5.8: Top N100 structure map. This horizon is $3.65 \mathrm{Ma}$ at IODP U1352. The legend to the right shows the depth in metres from mean sea level. The black circles show the wells labelled in Fig. 1.1. 


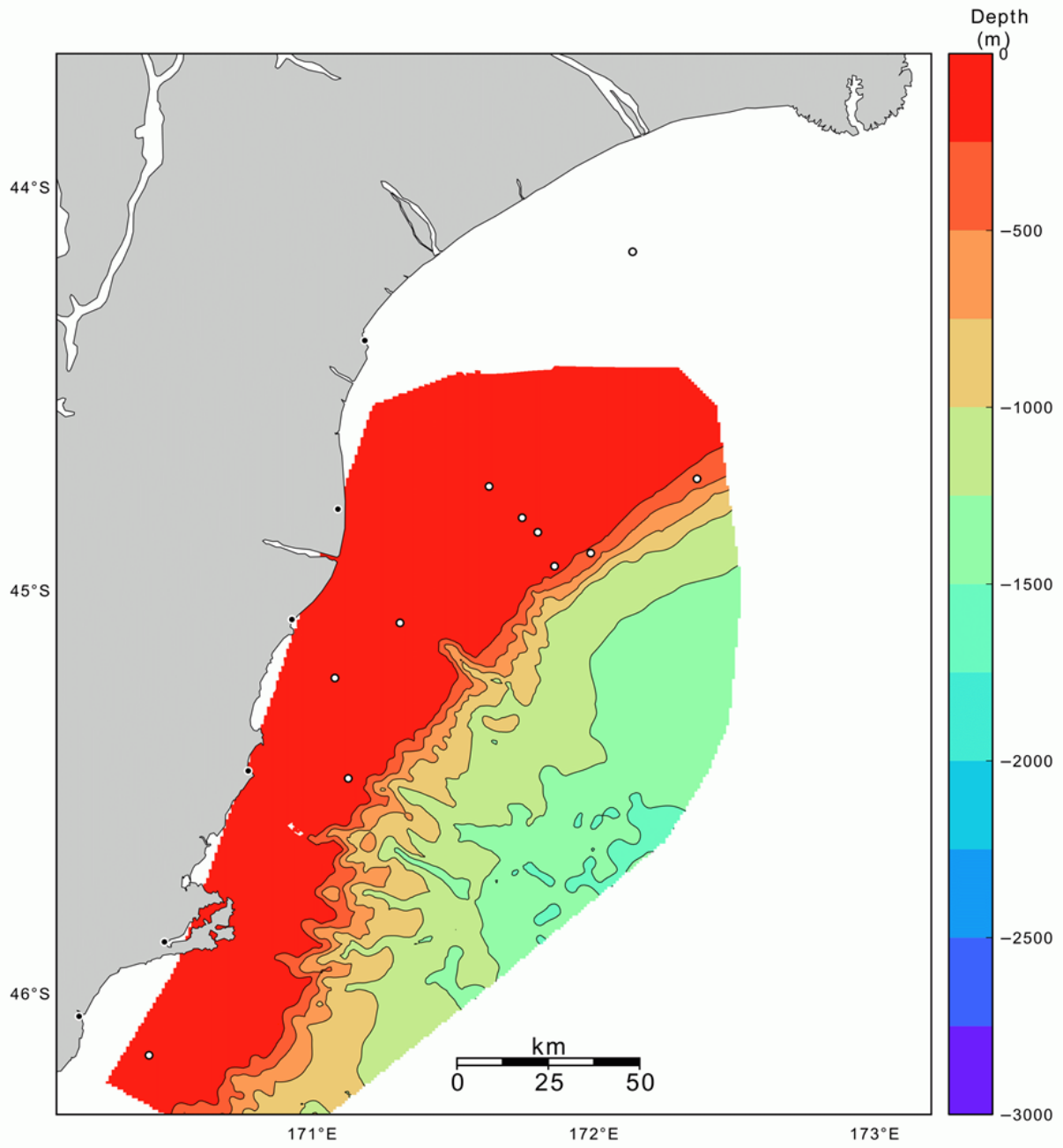

Fig. A5.9: Seafloor structure map. The legend to the right shows the depth in metres. The black circles show the wells labelled in Fig. 1.1. 


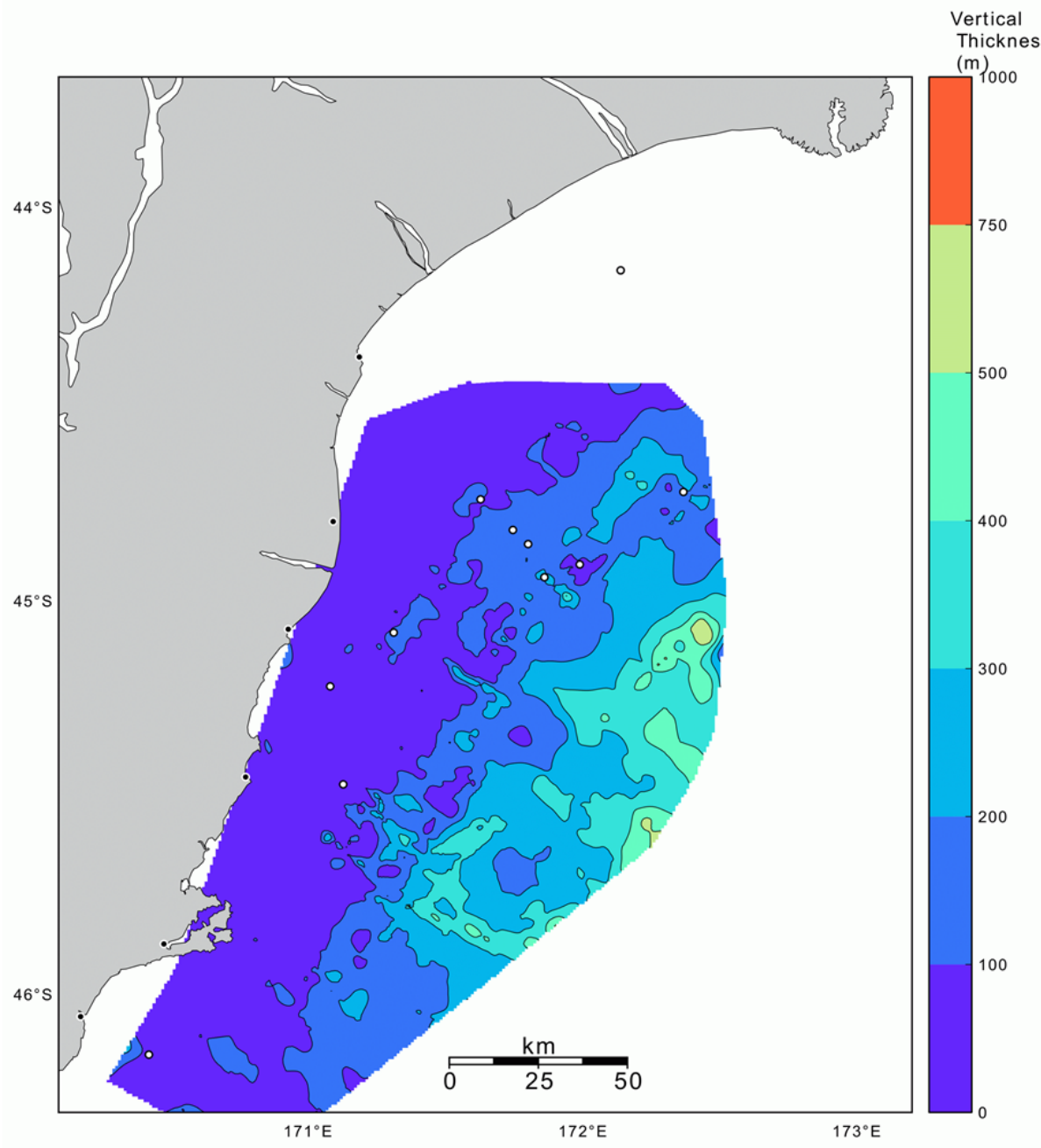

Fig. A5.10: Top N10-Top T70 isopach map. The legend to the right shows the depth in metres. The black circles show the wells labelled in Fig. 1.1. 


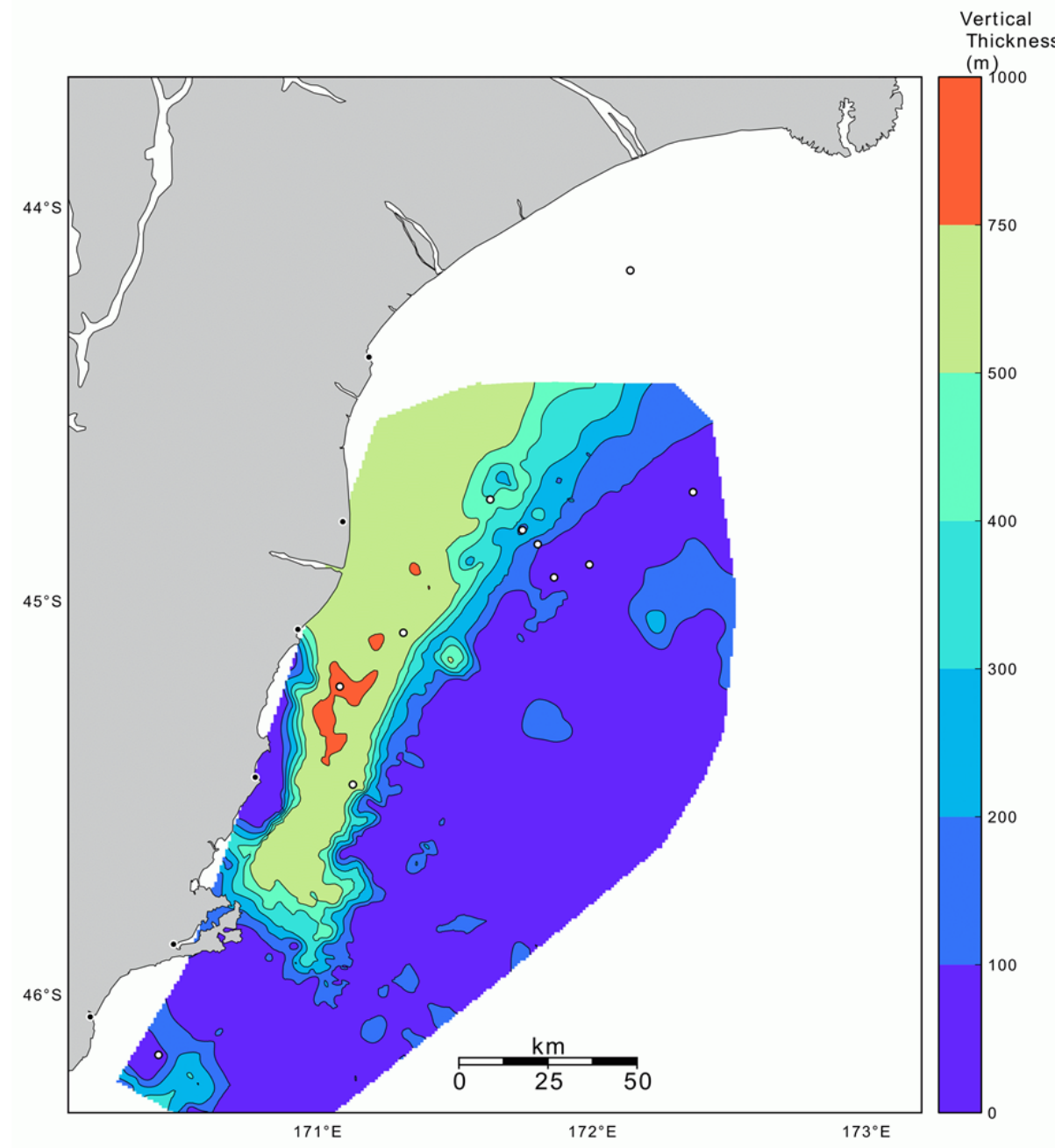

Fig. A5.11: Top N20 - Top N10 isopach map. The legend to the right shows the depth in metres. The black circles show the wells labelled in Fig. 1.1. 


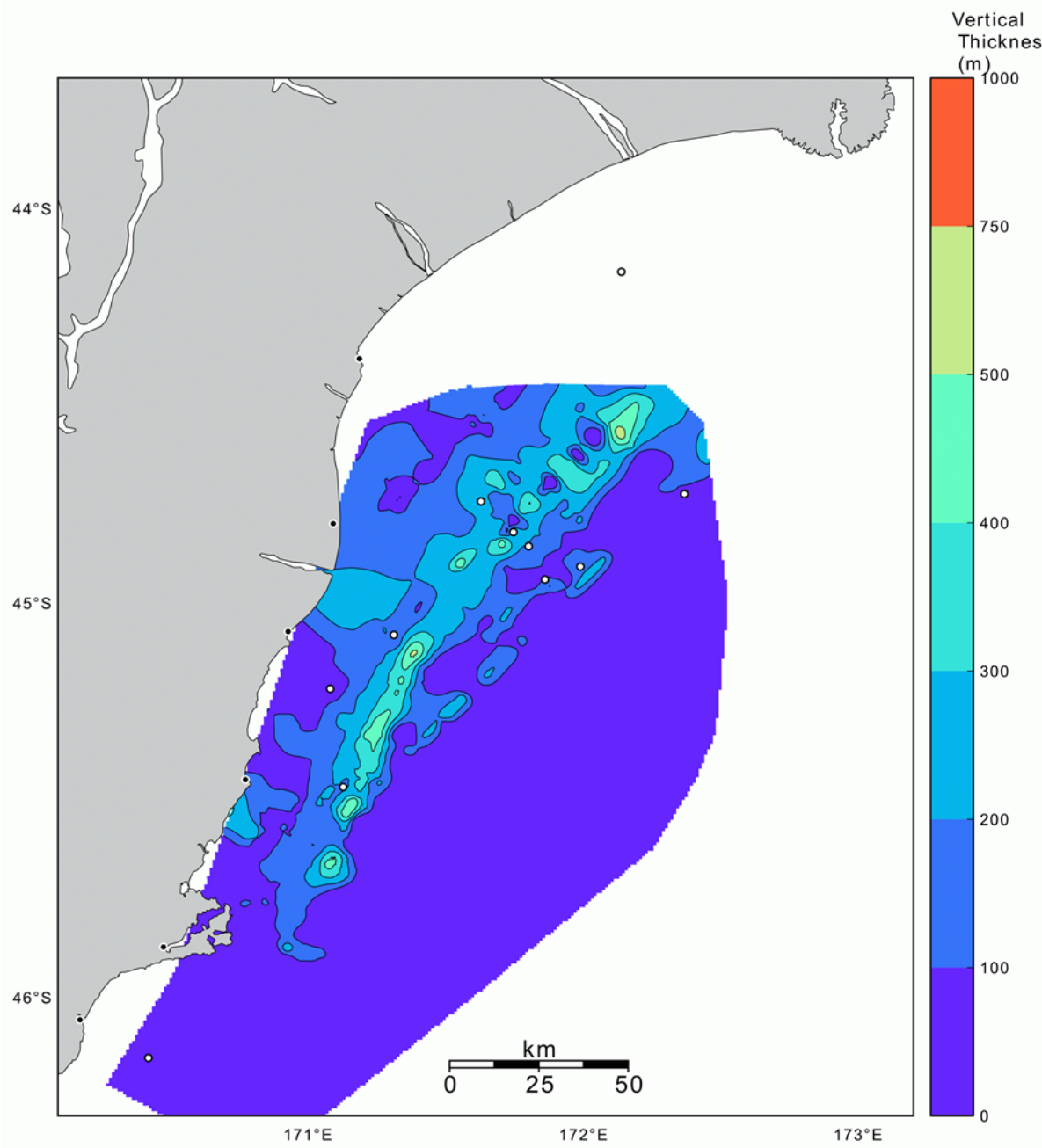

Fig. A5.12: Top N30 - Top N20 isopach map. The legend to the right shows the depth in metres. The black circles show the wells labelled in Fig. 1.1. 


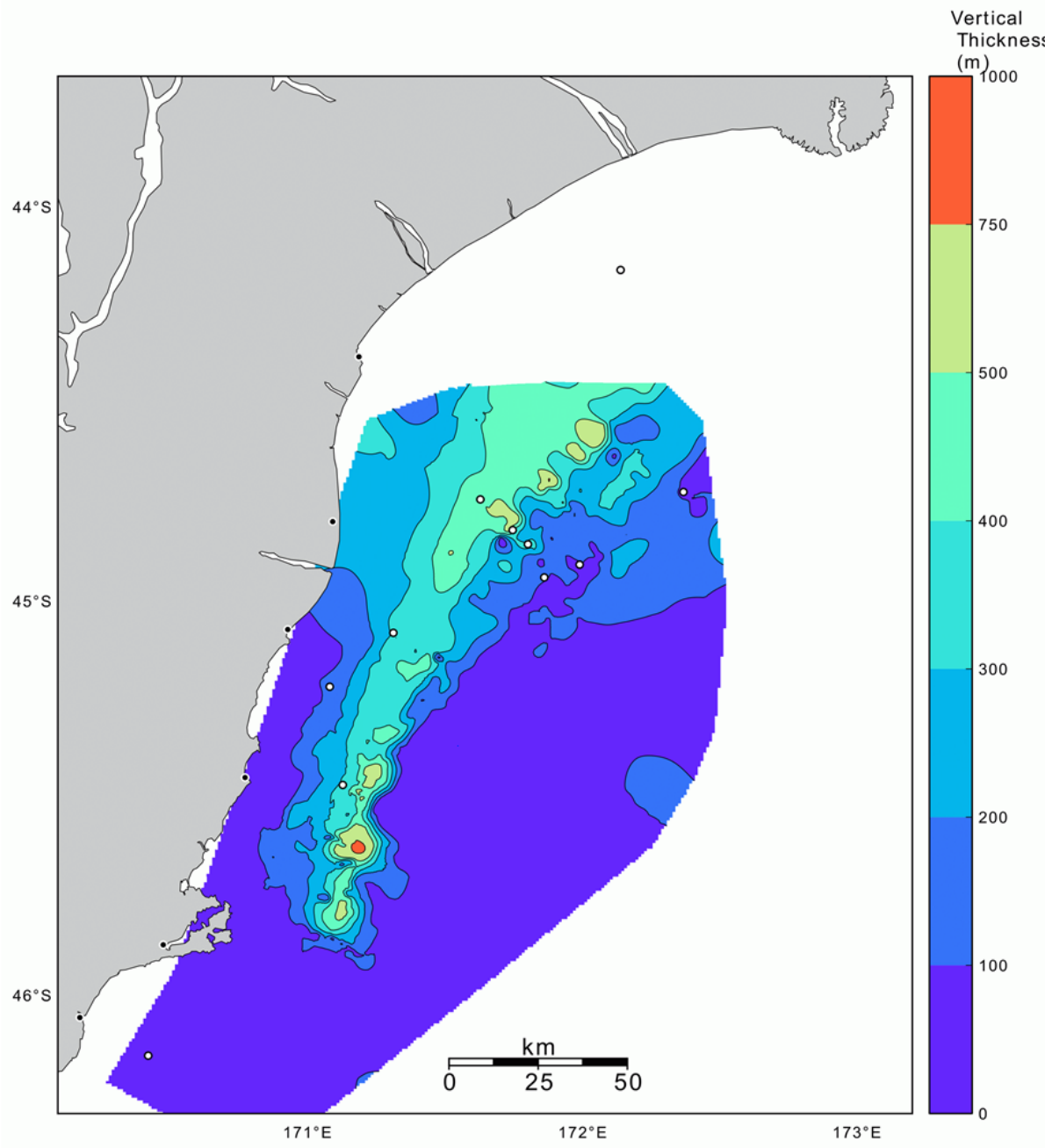

Fig. A5.13: Top N50 - Top N30 isopach map. The legend to the right shows the depth in metres. The black circles show the wells labelled in Fig. 1.1. 


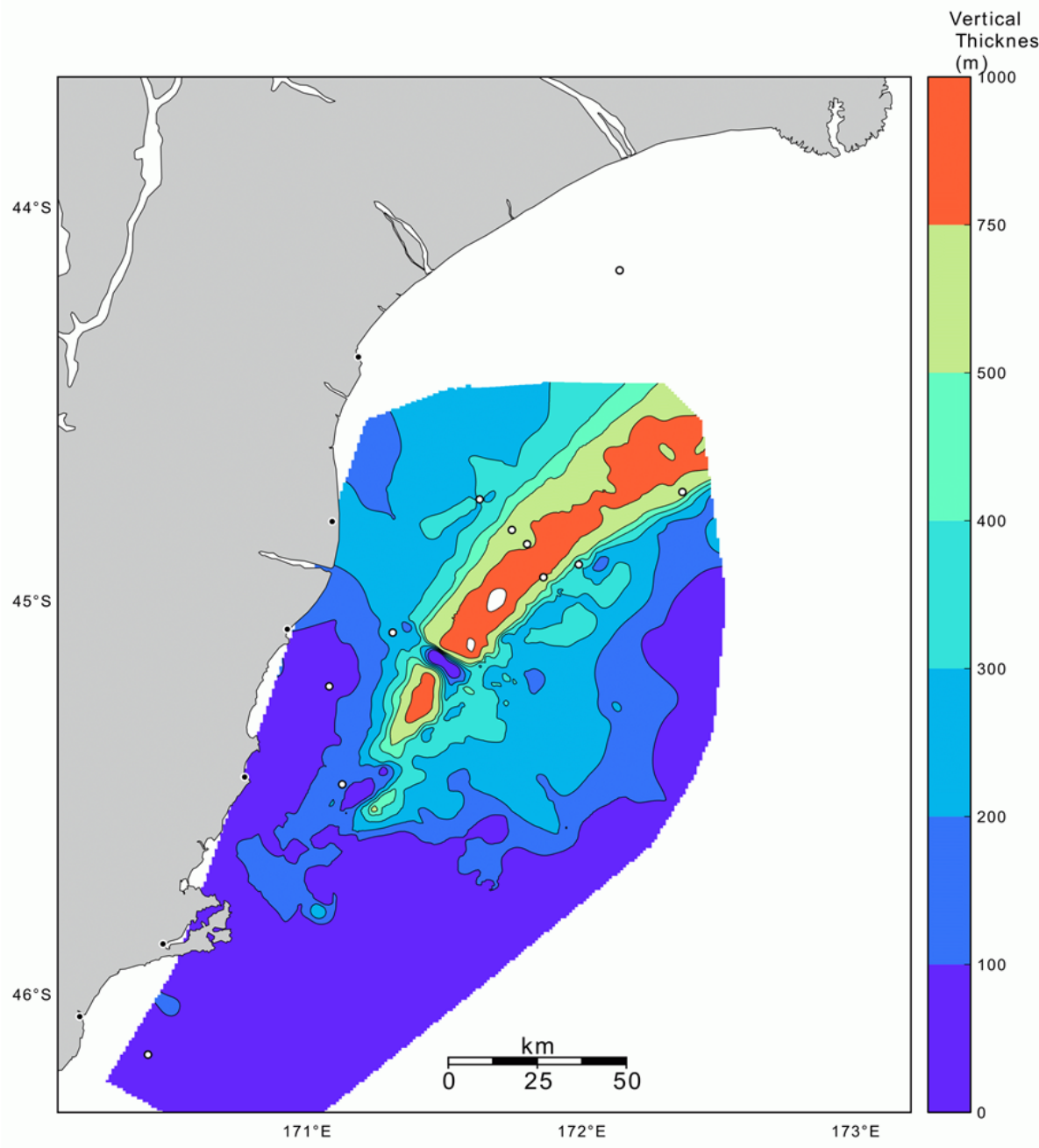

Fig. A5.14: Top N80-Top N50 isopach map. The legend to the right shows the depth in metres. The black circles show the wells which are labelled in Fig. 1.1. 


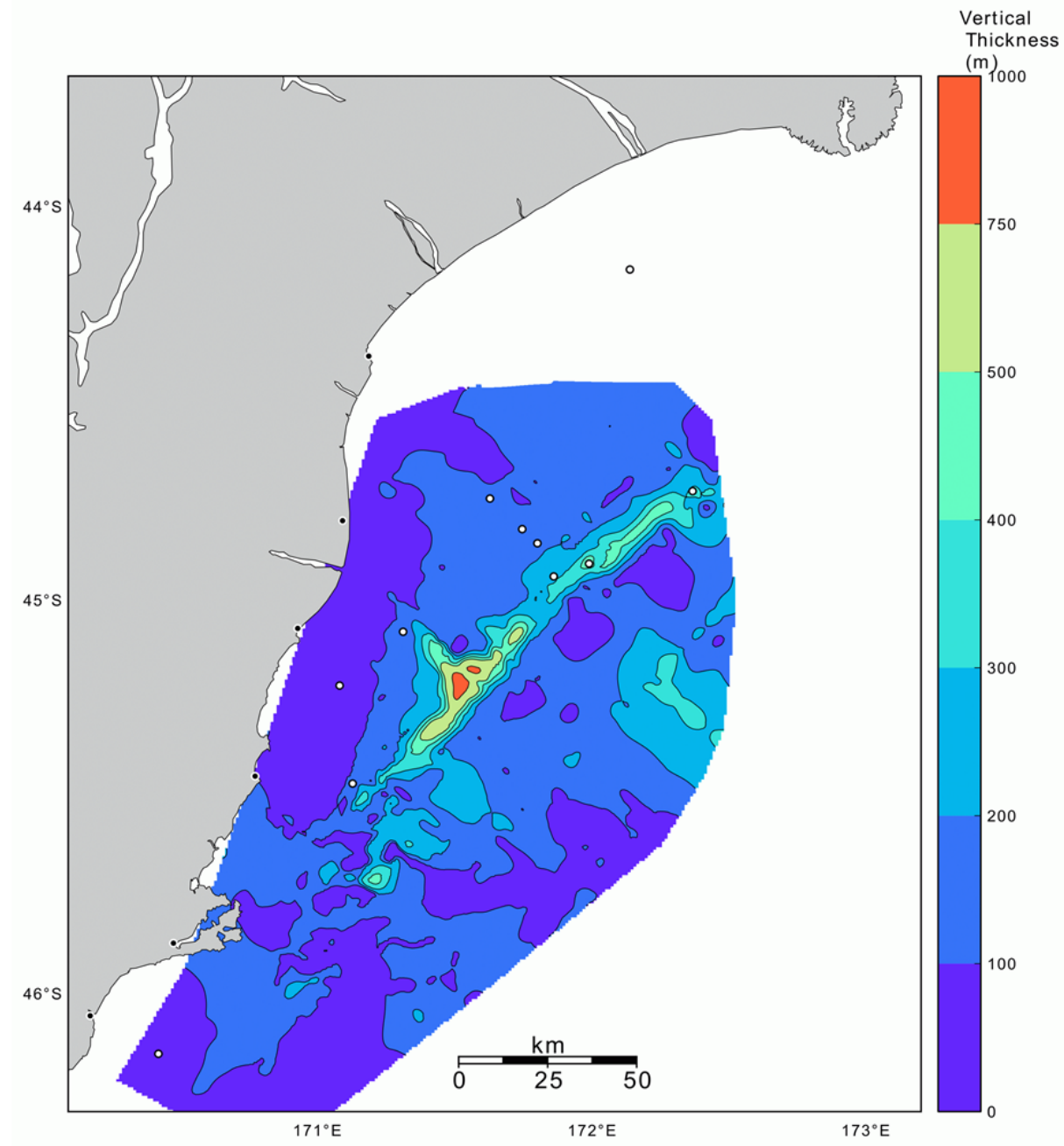

Fig. A5.15: Top N100-Top N80 isopach map. The legend to the right shows the depth in metres. The black circles show the wells labelled in Fig. 1.1. 


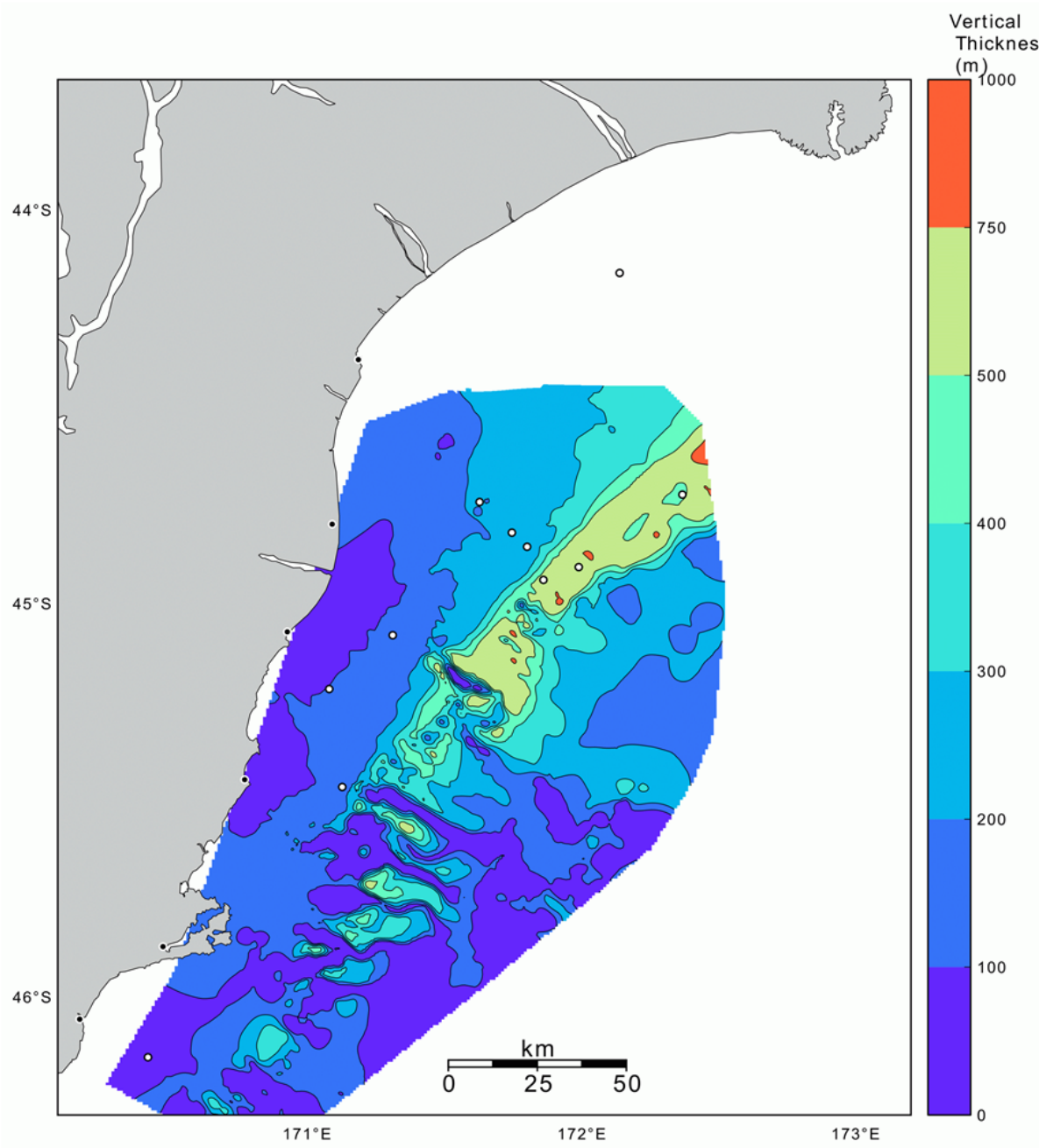

Fig. A5.16: Seafloor-Top N100 isopach map. The legend to the right shows the depth in metres. The black circles show the wells labelled in Fig. 1.1. 